\title{
محاولة البابا أوربان الخامس نقل مقر البابوية من أفينون إلى روما
}

\author{
فاطمة بكر عبد ريه حسين \\ باحثة دكتوراة - كلية الآداب - جامعة الفيوم
}

\section{مقََّمةُُ}

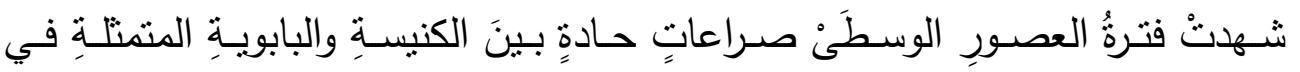

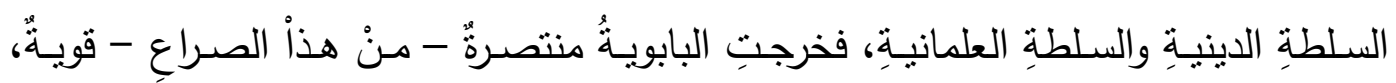

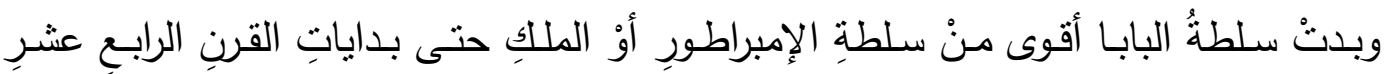

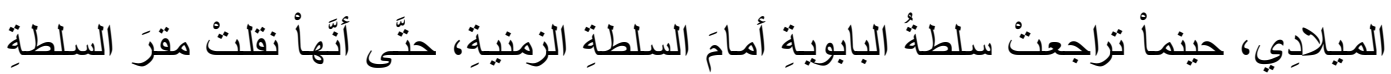

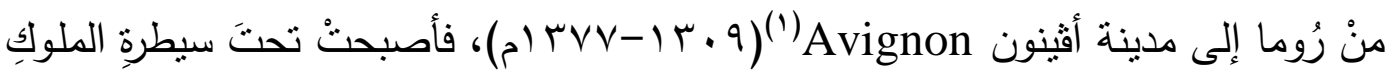

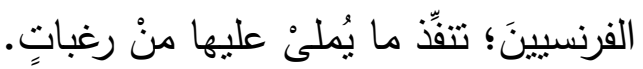

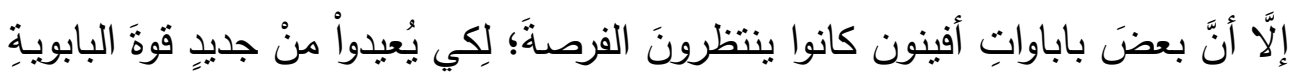

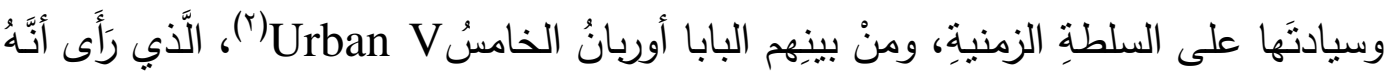

(') أفينون: مدينة فرنسية نقع عند النقاء نهري الرون ودورانس Durance، وبوقوع أفينون على نهر الرون وجسر القديس بنزيت مt. Benezet، أصبحت خلاهل القرن الرابع عشر الميلادي مدينة تجارية ونقطة

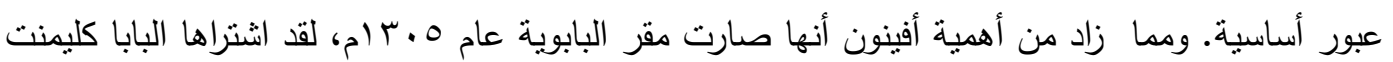

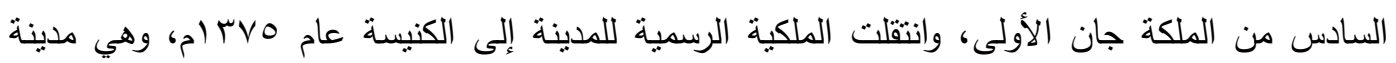

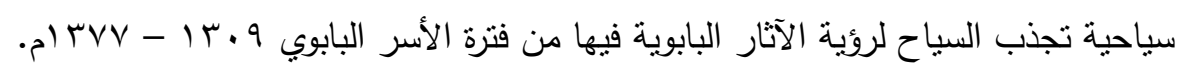
Reouard, Y., La papaute à Avignon, Paris, 1954, p. 26; Girard, J., Evocation du vieil Avignon, Paris, 1990, p. 25; Chelini J., L'église au temps des schismes 1294 -1449, Armad Colin, Paris, 1982, p. 35; Christophe, J. B., Histoire de la papauté pendant le xive siècle, 2 Toms, Paris, 1853, Tome 2, pp. 467-471;

ساهل يوسف، "البابوية في مدينة أفينون في القرن ـام ام وتأثيرها على الأوضاع العامة في أوروبا

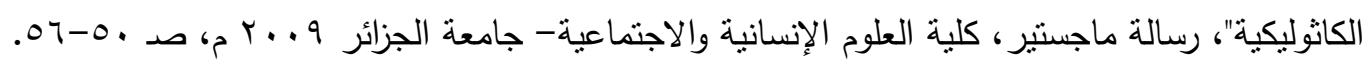

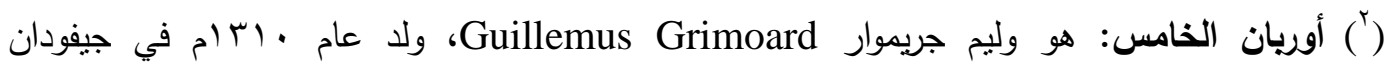
Gevandan عُرف باسم وليم لانجدوك William Languedoc نسبة إلى مقاطعته، ودرس الفنون والقانون الدندي لإني

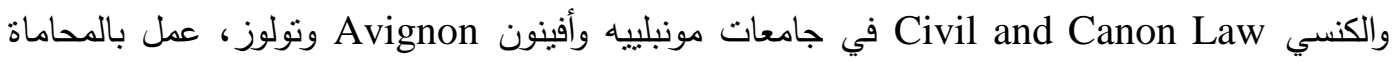

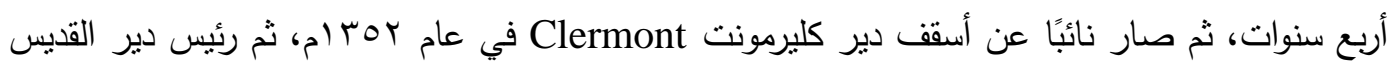

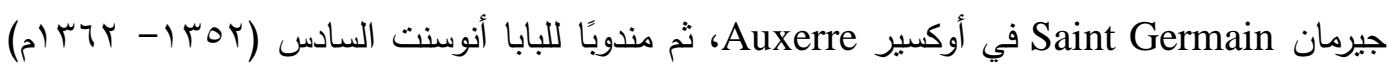




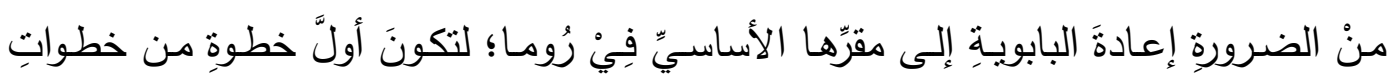

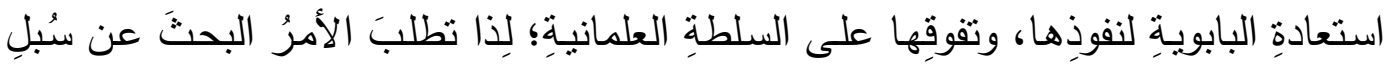

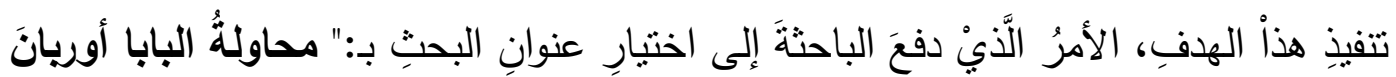

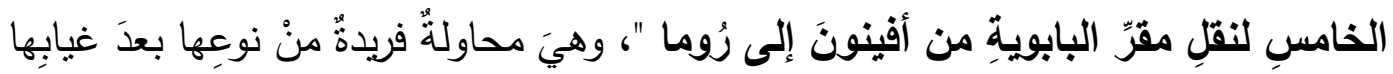

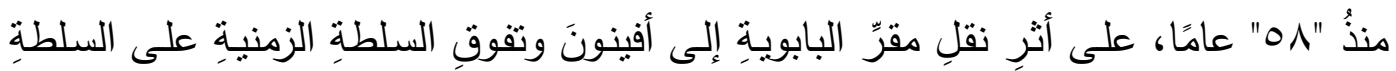

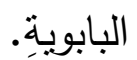

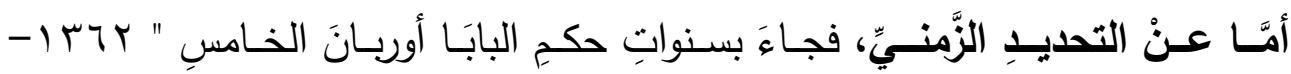

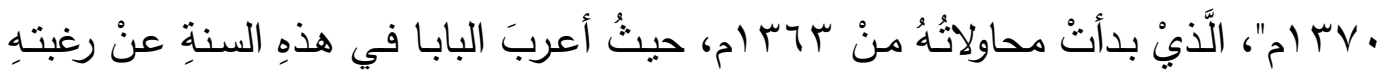

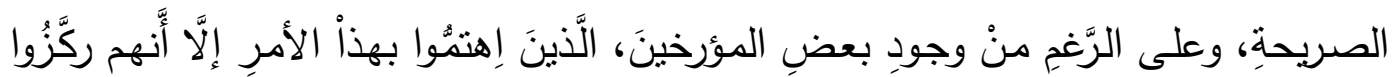

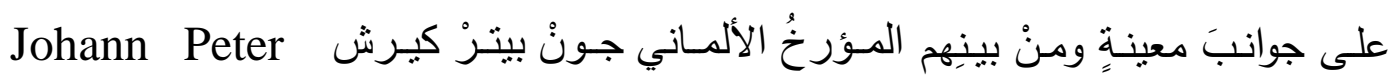
(')Kirsch

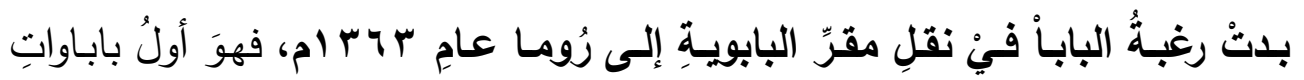

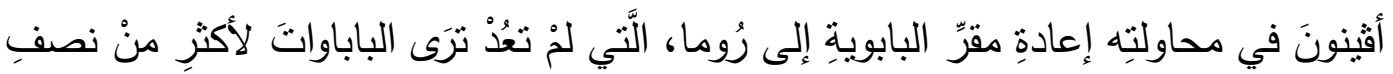

Innocent VI

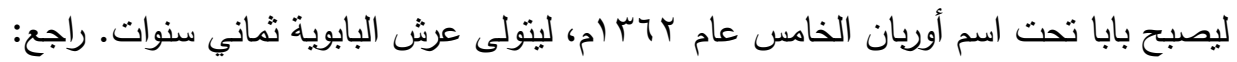

Du Chesne, F., Histoire de tous les cardinaux François de Naissance, 2 Tomes, Paris, 1660, pp. 580-581; Moreri, M. L., Le grand dictionnaire historique ou le mélange curieux de l'histoire sacrée et profane, Vol. 10, Paris, 1759, pp. 716-718; L'Abbé Magnan, Histoire d'Urbain $V$ et de son siècle d'après les manuscrits du Vatican, Paris, 1863, pp. 10-30; L'Abbe M. Chaillan, Le bienheureux Urbain V (1310 -1370), Paris, 1911, pp. 3-24.

( $\left.{ }^{1}\right)$ Kirsch, J. P., Die Ruckkehr der papste Urban V. und Gregor XI. von Avignon nach Rom: Ausziige aus den Kameralregistern des Vatikanischen Archivs, Paderborn, 1898.

انصبت هذه الدراسة على الاهتمام بالجوانب الاقتصادية التي ترتبت على محاولة نقل مقر اللبابية من

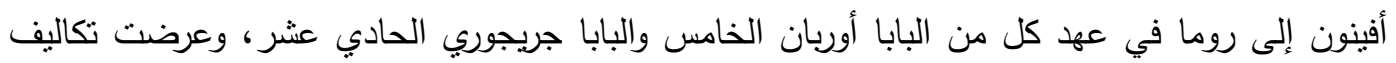

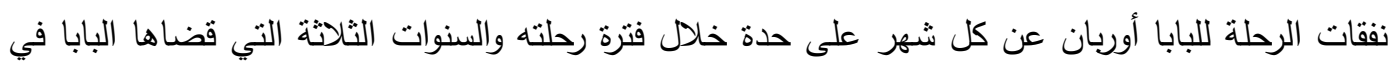

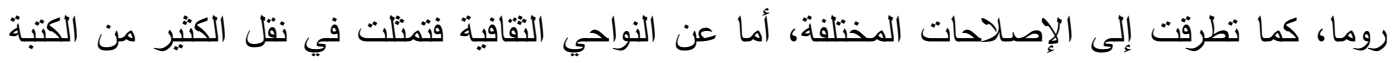
والموظفين ونسخ الكثير من سجلات أفينون، ونقلها إلى الفاتيكان، وإصلاح وإنثاء العديد من المؤسسات الدينية والثقافية. 


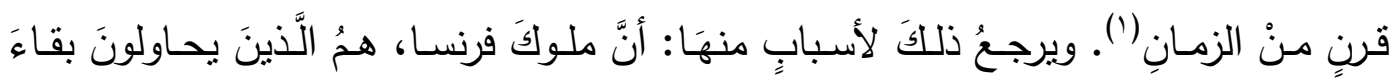

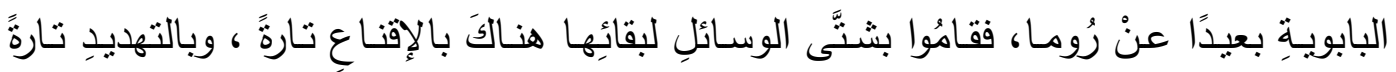
أُخرىن، وبالتالي باتَّ واضحًا سقوطُ البابويةِ في العبوديةِ؛ لذا أظهرَ البعضُ قلقًا واضحًا بشأنِ بقائها في أفينونَ، إلَّا أنَّهَ كانَ منْ الصنَّعبِ على الباباواتِ السابقينَ، وعلى البابا أوربـانَ القيامُ

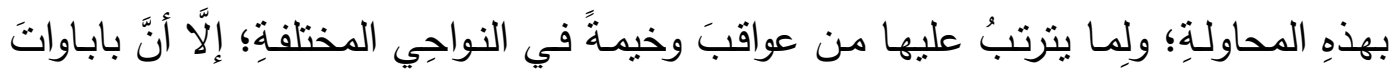

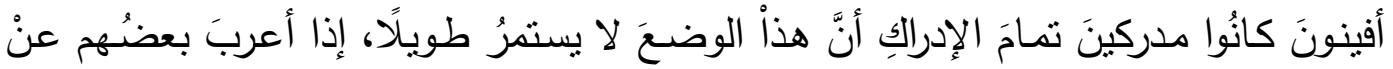

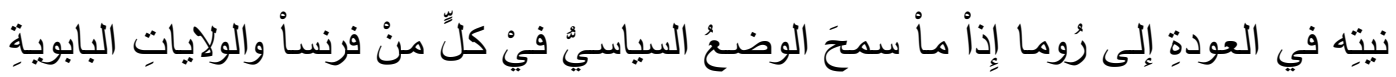

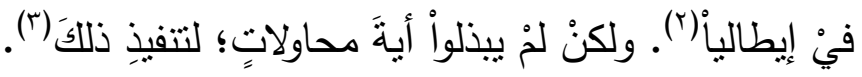

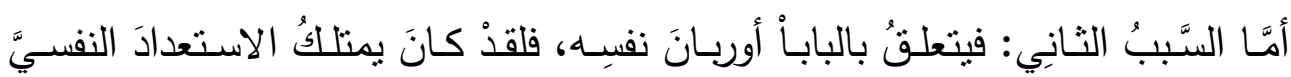

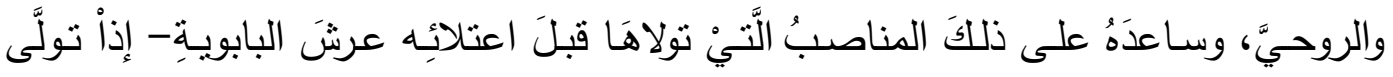

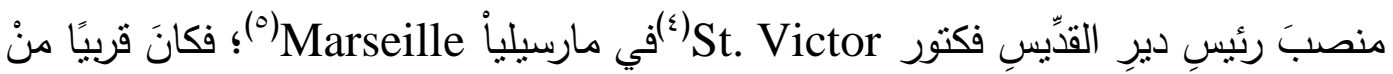

(1) Matteo Villani, Istorie di Matteo Villani Cittadino fiorentino, Firenze. 1581, Tome. 2, C.26, pp. 315 - 316; Christophe, Histoire de la Papauté, Tome. 2, p. 365; Stephenson, C., Medieval History, New York, 1943, p. 502.

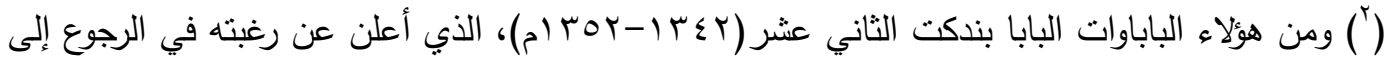

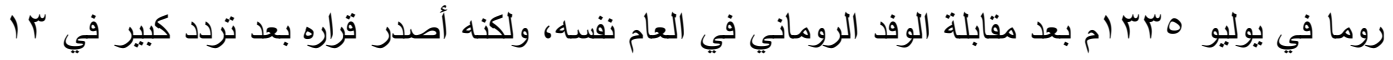

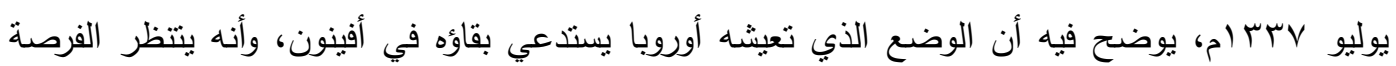

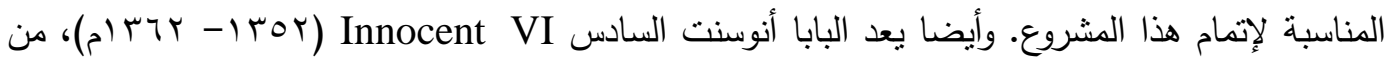
أول باباوات أفينون الذين فكروا بجدية في نقل مقر البابوية إلى روما، إذ أن روما هي المدينة التي نشأت

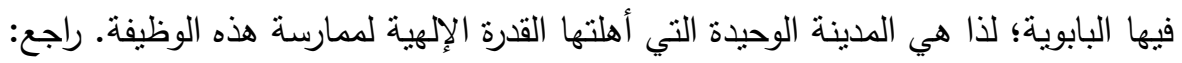

ساهل يوسف، "البابوية في مدينة أفينون"، صد عـ-10ـ. Pastor, Histoire des papes, p. 110

$\left({ }^{3}\right)$ Christophe, Histoire de la papauté, Tome. 2, pp. 45-46; Kirsch, Die Ruckkehr der Papste Urban V, pp. V-VI.

John دير سانت فيكتور: نم تأسيسه في القرن الخامس الميلادي على يد القديس يوحنا كاسيان

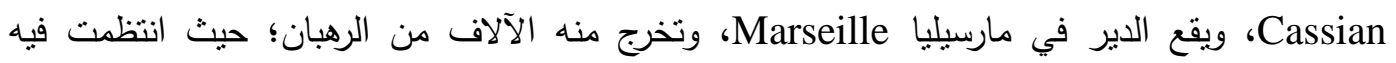
الرهبانية على يد القديس إسارن Isarn في القرن الحادي عشر المبلادي، ونم إنشاء العديد من الأديرة

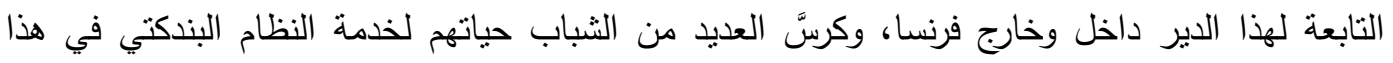
Chaillan, Le Bienheureux, pp. 7- 10. ( ) مارسيليا: مدينة فرنسية قديمة، وثاني أكبر المدن الفرنسية، تقع جنوب شرق باريس عند مصب نهر

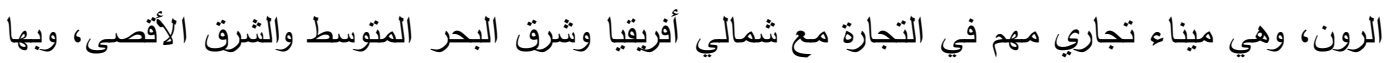

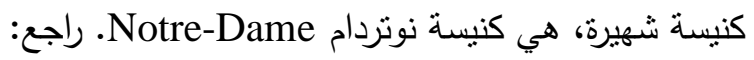




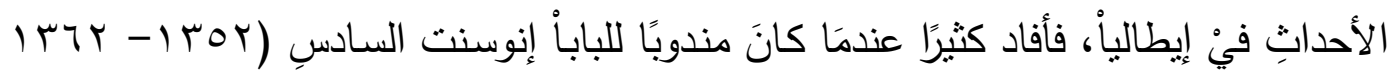
م) Innocent VI' في إيطالياْ للعملِ على إعادةِ الاستقرارِ والأمنِ بينَ ولاياتِهاْ التابعةِ

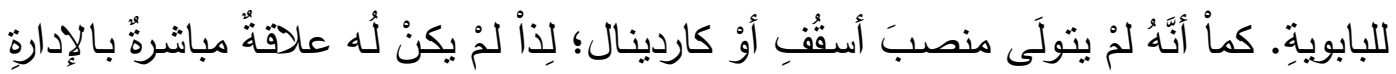

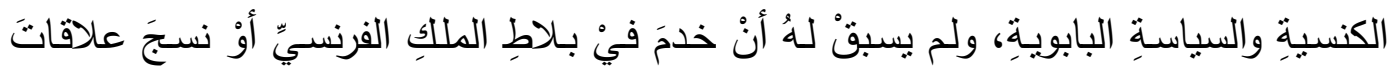

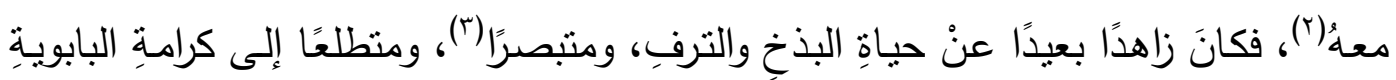

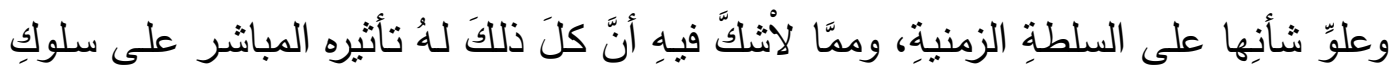

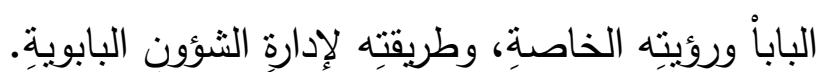

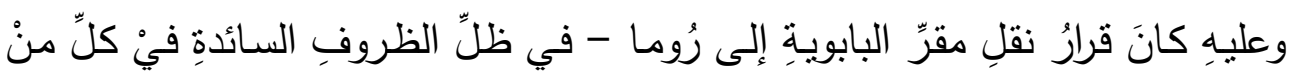

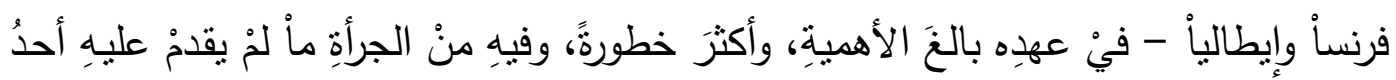

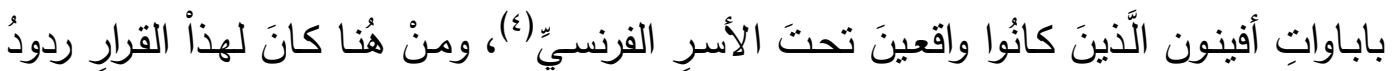

Bouillet, M. N., Dictionnaire universel d'histoire et de géographie, Paris, 1878, p. 1198; Moore, W. G., The Penguin Encyclopedia of places, New York, 1978, p. 498.

Etienne أنوسنت السادس: أحد باباوات أفينون، السابق على البابا أوربان الخامس، وهو إنيان أوبير (') Aubert ولد في عام r Y ام في مقاطعة مون Monts بالقرب من بمبادور Pampadour، وبدأ حياته

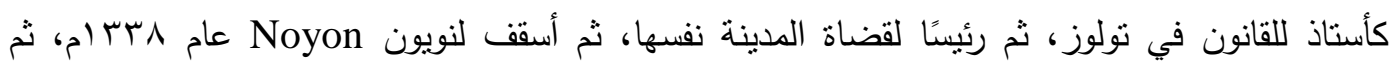

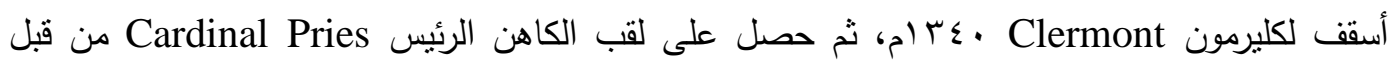

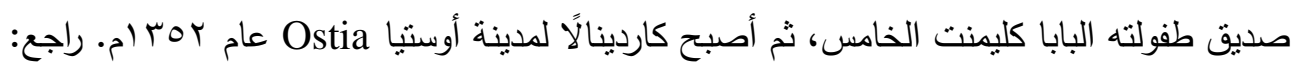

Kelly, J. N. O., The Oxford Dictionary of Popes, Oxford, 1996, pp. 221-223; P. Gasnault and M. H. Laurent (eds.), Innocent VI: Lettres secretes et curiales, Paris, 1959.

$\left({ }^{2}\right)$ Renouard, Y., La papauté à Avignon, Paris, 1954, p. 49.

$\left({ }^{3}\right)$ Froissart, J., Les Chroniques, dans Historiens et chroniqueurs du moyen age, texte établi et annoté par A. Pauphilet, Gallimard, Bruges, 1963, T. VI, p. 504; Mollat, G., Les papes d'Avignon (1305-1378), 3 ème éd., Librairie Victor Lecoffre, Paris, 1920, pp. 105-111.

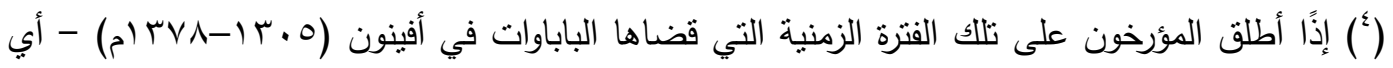

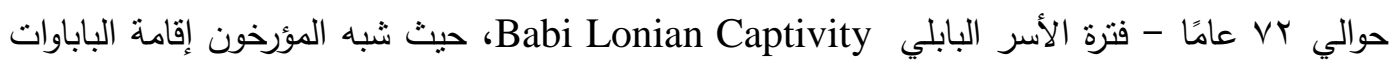
الإجبارية تحت النفوذ الفرنسي بفترة سبي بني إسرائيل من قبل الملك نبوخذ نصر الثاني Naburchodosor وإكراههم على السكن في مدينة بابل العراقية، فكان هناك المؤيدين والمعارضين، والذي كان منهم فرانسوا بترارك F. Petraque، التي سماه بالأسر البابلي، كما وصف أفينون ببابل المحتلة والمنافقة والثريرة، ومدرسة الخطايا ومعبد الهراطقة، في حين اعتبر دانتي إليجيري Dante Alegieri أن البابا كليمنت بالت

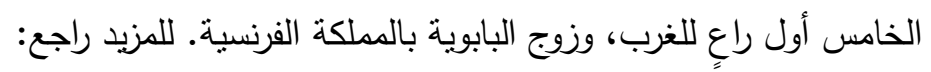




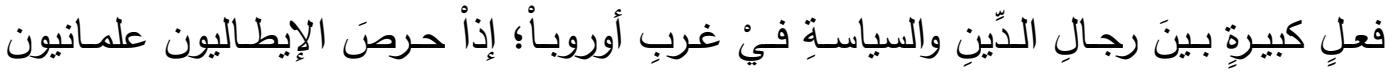

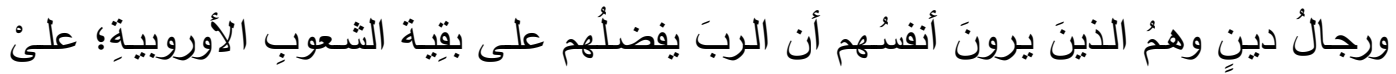
وجودِ مقرِّ البابوية، ومقرَّ القديسين - بيير وبولس - على أراضِيهه، ومنْ هُنا كانُوا حربصينَ

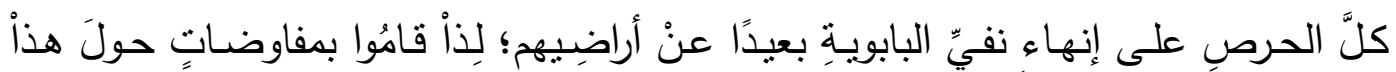

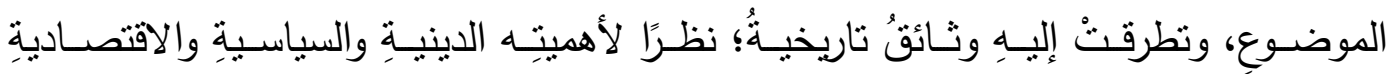

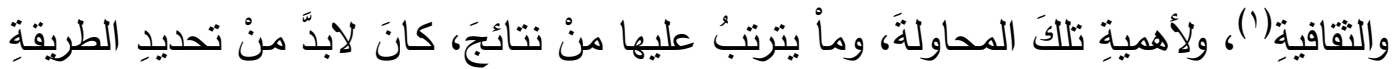

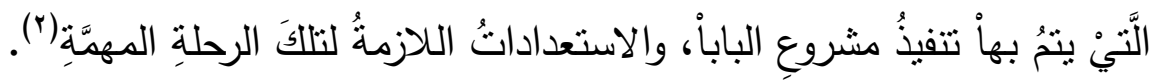

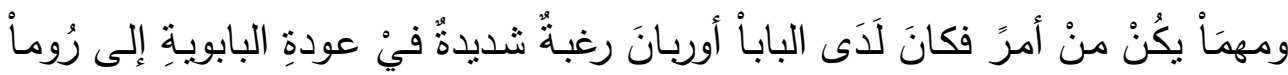
مرةً أُخرى منذُ اعتلائهِ عرشَ البابويةِة، إذْ أعربَ للسفراءِ الإيطاليينَ عنْ هذهِ الرغبةِ عندمأ زارهُ

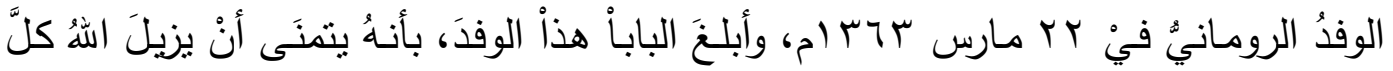
العراقيلِ؛ ليعودَ إلى رُومأ(r).

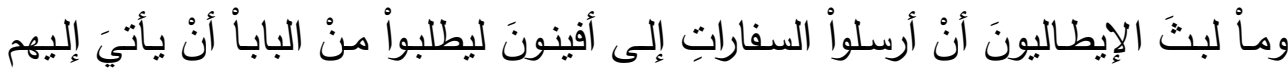

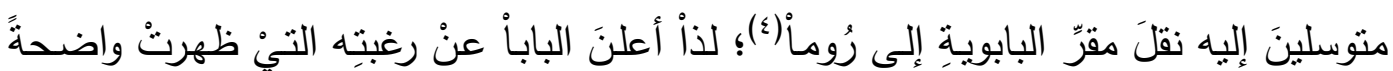

Petraque, F., Les rimes de François Petraque, trad. F. Reynard, Paris, 1883, sonnet, XVI, p. 356; Dante, La devine comédie, trad. H. Largnon et G. Frères, Paris, 1966, Enfer, chant. XIX; Pirenne, H., Augustin Renaudet, La fin du moyen age la desagregation du monfe medieval (1285-1453), Tome. I, Paris. 1931, pp. 53-56; Pastor, Histoire des papes, p. 73;

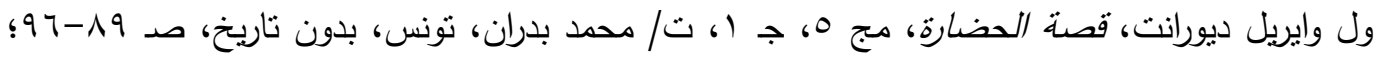
وفاء المزروع، "انثقاق البابوية في العصور الوسطى وأثره على الأوضاع السياسية"، مجلة كلية الآداب -

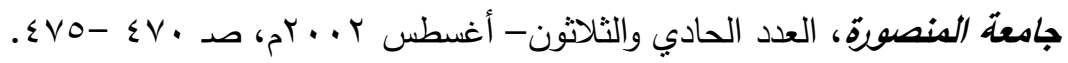

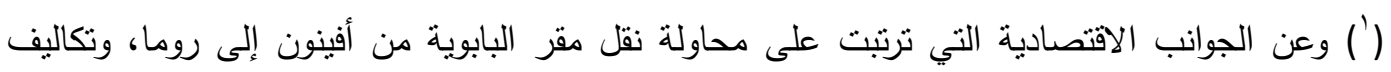

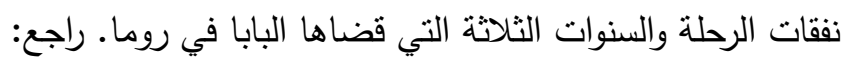

Kirsch, Die Ruckkehr der Papste Urban V, pp. II-VI.

$\left.{ }^{2}{ }^{2}\right)$ Raynaldi et Jac. Laderchii, Annales Ecclesiastici, Tome. 26, Paris, 1880. ad ann. 1364-1366, pp. 80-139; Prou, M., Etude sur les relations politiques du pape Urbain V avec les rois de France Jean II et Charles V, Paris, 1888, pp. 6-20; G., Ferdinand, History of the city of Rome in the middle ages, Trans. A. Hamilton, Vol. VI, Part . II, London, 1898, pp. 390-400.

$\left(^{3}\right)$ Bréhier, D., Notre Dame des Doms, Ed Beaulieu, Art et Tradition, Lyon, 2002,

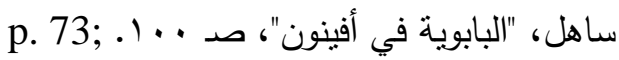

$\left({ }^{4}\right)$ Baluzius, Vitae paparum avenionensium, Tome 1, pp. 400 - 402; J. H, Albanès, Vies antiques du pape Urbbain $V$ ( par des auteurs cintemporains autres anterieur au XVI siècle), Ulysse Chevalier, 1897, p. 70; Christophe, Histoire de la Papauté, T. 2, p. 360; Raynaldi, Annales Ecc., T. 26, ann. 1364, n. 11-12, pp. 93-94. 


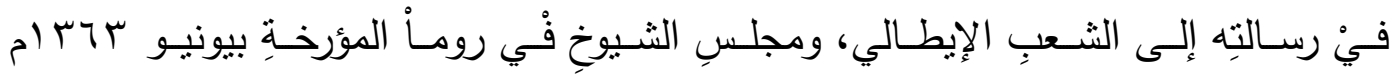
قائلاً:"... فأعزٌّ أُمنياتِي أنْ أَرَى الباباْ جالسًا على كرسيِّ القديسِ بيير ، وأنْ يصلَ إلى مدينسة

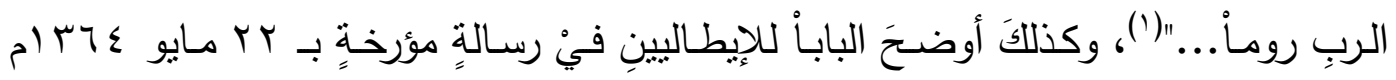
بقولـهـ"... بـأنَّ هنـاكَ بعضَ العوائقتِ..." يقصـدُ بـذللكَ الاضـطراباتَّ السـائدةَ فْي إيطاليـا،

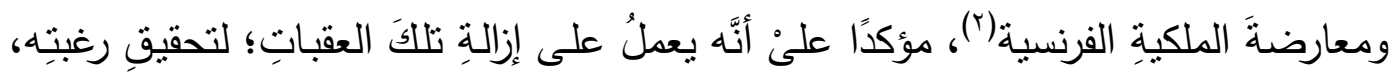
ووعدَهُم بأنَّهَ سيرسلُ حملاتِ استكثافيةً للفصلِ فيْ المشاكلِ التيْ تواجهُ الولاياتِ البابويةِ فيْ إيطاليا، مشيرًا إلى أنَّه قررَ القيامَ بأعمالٍ تمهيديةٍ وإصلاحيةٍ فيْ تللكَ الولاياتِ منْ أجلِ إنفاذِ

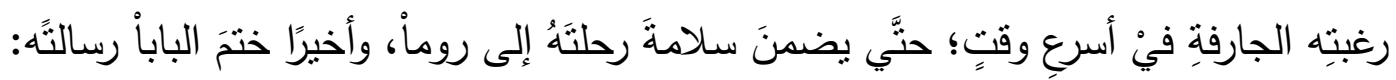

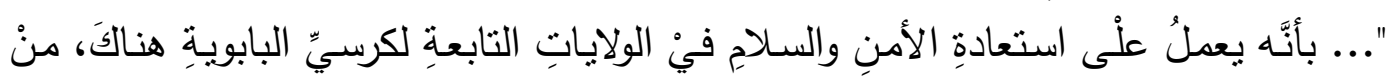

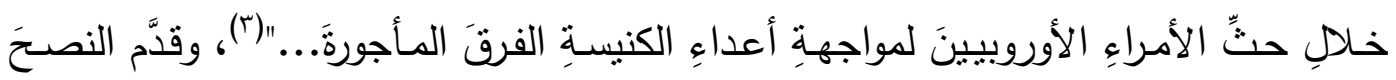

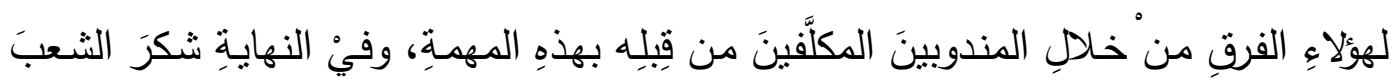

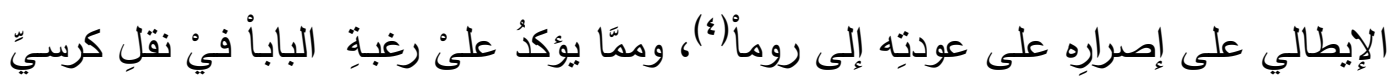

(1) Theiner, A., Codex diplomaticus dominii temporalis S. Sedis, extraits des Archivio du vaticano, Tome II (1335-1389), Rome, 1862, N. 382, p. 410.

(†) كما واصلت روما وفلورنسة وبعض الثخصيات الإيطالية الثهيرة جهودها لإعادة الأمجاد الأدبية في

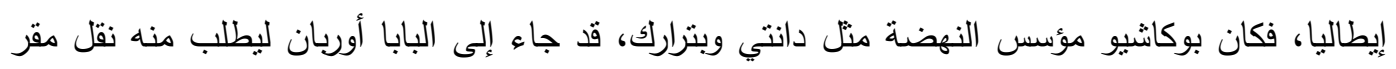

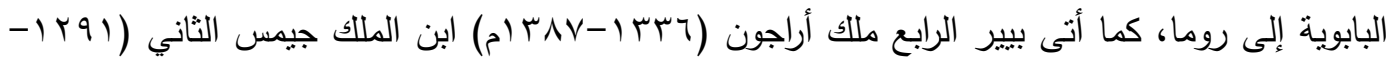
V Vrr (ام)، وكرر نفس الطلب السابق؛ وذللك لإصلاح الكنيسة الجامعة في روما. للمزيد راجع:

Chaillan, Le Bienheureux, p. 152; Petraque, Les rimes de François Petraque, XVI, p. 356.

(") انتشرت الفرق المأجورة في إيطاليا منذ بداية القرن الرابع عشر الميلادي، وكانت حياة هذه الفرق فيها

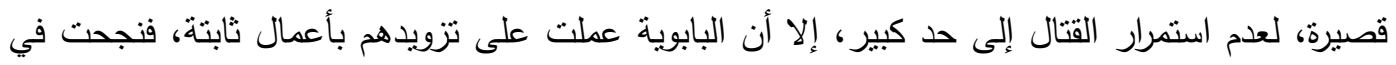

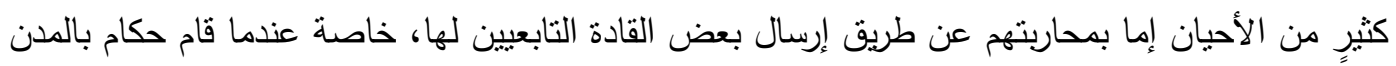
الإيطالية بالاستعانة بهم في السيطرة على المدن التابعة للبابوية في إيطاليا، وإما باستجارتهم كما حدث في بـاني

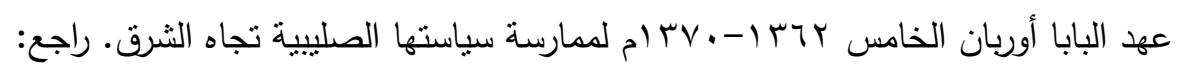

Partner, P., The Lands of St. Peter. The Papal State in the Middle Ages and the Early Renaissance, London, 1972, pp. 339-365; Denifle, H., La désolation des églises, monastères et hôpitaux en France pendant la Guerre de Cent ans, Tome. II, Paris, 1899, pp. 450-451; Christophe, Histoire de la papauté, T. 2, pp. 350351.

$\left({ }^{4}\right)$ Lettres d'Avignon secrètes du pape Urbain V, Tome. I, Fol. 158; Theiner, Codex diplomaticus, T. II, N. 382, p. 410; Christophe, Histoire de la papaute, II, p. 566; Kirsch, Die Ruckkehr der Papste Urban V, p. IX. 


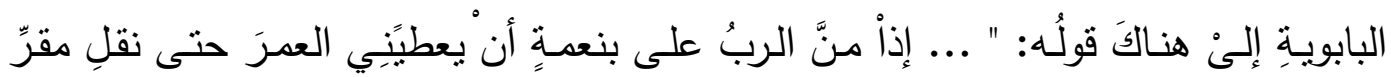

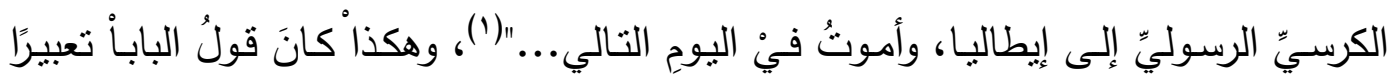

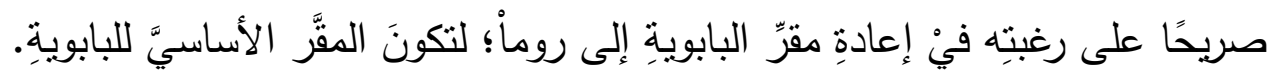

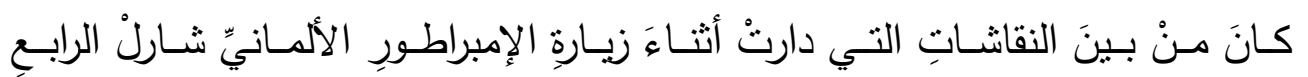

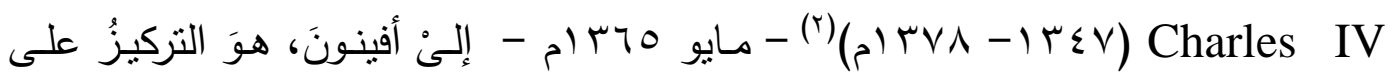
عودةِ الباباً إلى روماً فيْ ظلِّ إلحاح منْ الكاردينالِ أَلْئورنوز

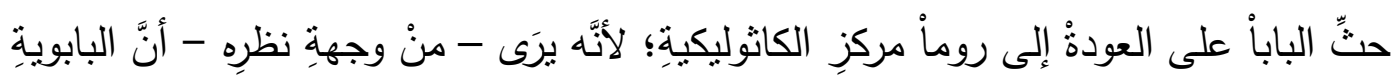

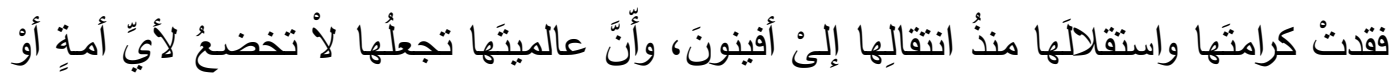

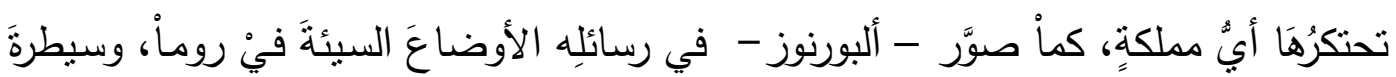

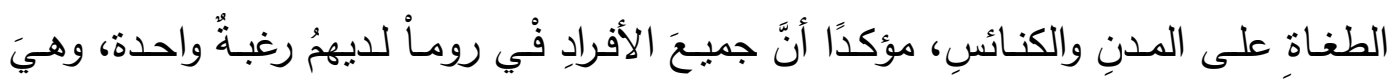

( $\left.{ }^{1}\right)$ Matteo Villani, Istorie di Matteo Villani cittadino fiorentino, Tome 2, C. 26, pp. 315 - 316; Christophe, Histoire de la Papauté, p. 365.

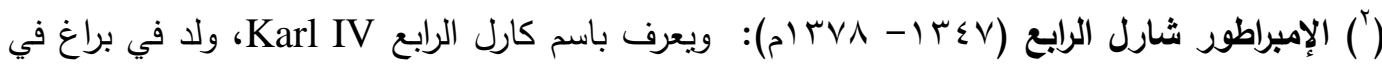

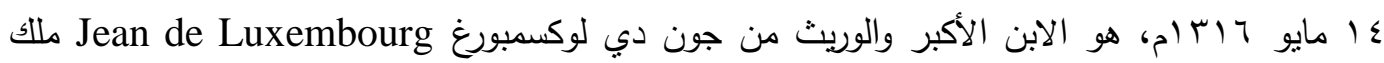

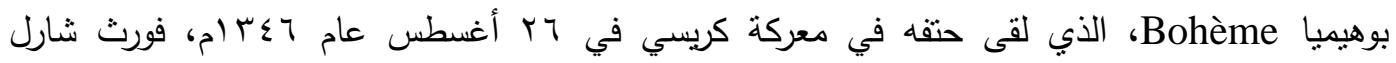

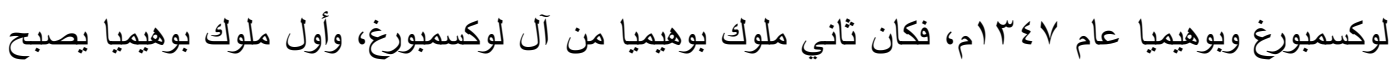

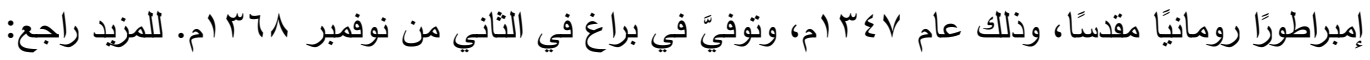
František, M. P., Geschichte Kaiser Karls des Vierten, Königs in Böhmen, 2 Vols, Walther, 1783; Bouillet, Dictionnaire universel d'histoire, p. 35; Werunsky, E., Geschichte Kaiser Karls IV und seiner Zeit, New York, 1961, (2 Teil).

(") ألبورنوز: ولد في كونيكا Cuença، إحدى مدن قثنالة Castiile، وأظهر موهبة في دراسة القانون في

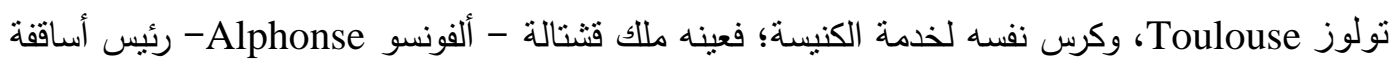
لطليطلة Tolède، وأخذ نصيحته في الحرب بين قشتالة والبرتغال، وبعد وفاة ألفونسو نولى ابنه بيير الأول

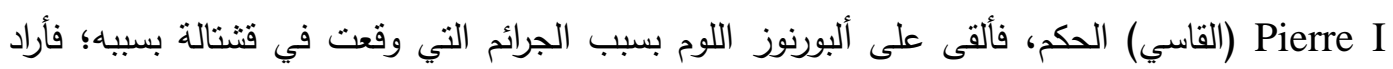

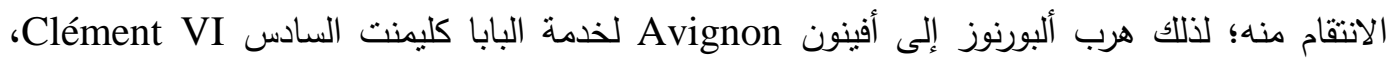

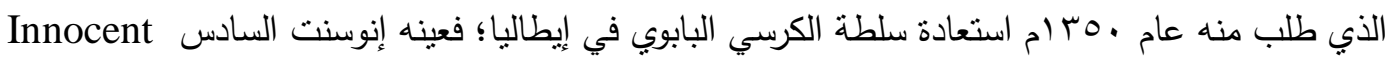
أسقفًا لسابينا Sabine VI

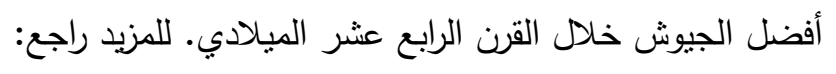

Chaillan, Le Bienheureux, pp. 17-21; Chevalier de L'escale, La vertu resuscitée, ou la vie du Cardinal Albornoz, urnomme ere de l'eglise, Paris 1629, Tome. 6, pp. 277-278. 


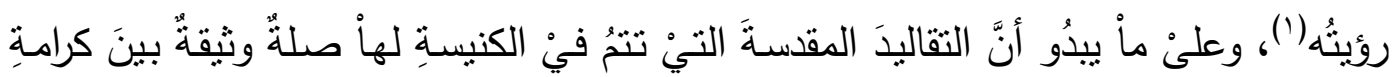
الباباً والإقامةِ فيْ رومأ.

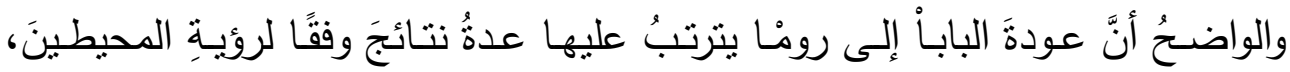

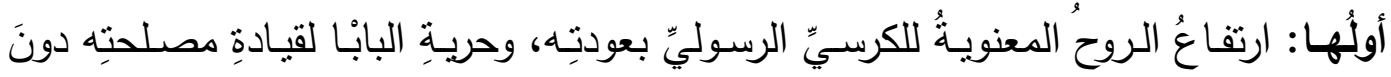

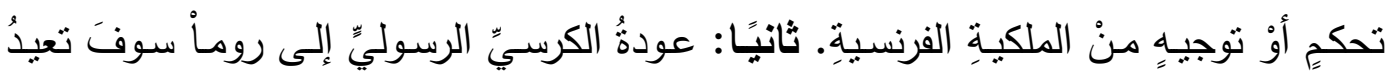
للإِيطاليينَ مكانتَهم الدينيةَ بينَ الأمِِ المسيحيةِ في الثرقِ والغربِ، وتعلى منْ كرامتهِه. ثُالثًا: اجتياحُ الفرقِ المأجورٍِ للولاياتِ البابويةِ فيَ إيطاليا وتهديد أمنُها، وكذلكَ تهديد استقرارَ وأمنَ

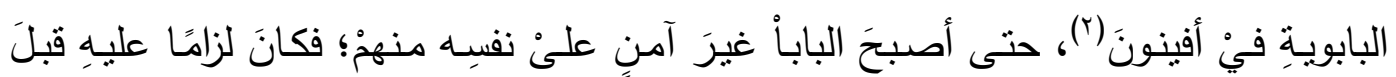
إعادةِ كرسيِّ البابويةِ إلى روماُ القضـاءُ على هذهِ الفرقِ وإعادةِ الاستقرارِ والأمنِ في إيطاليا

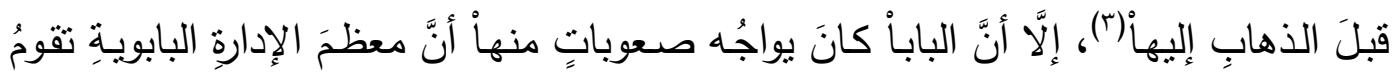
على عاتقِ المسؤولينَ الفرنسيينَ، ولابدَّ منْ أن بحل محلَّهم موظفونَ آخرونَ، كذلكَ انشغالُ

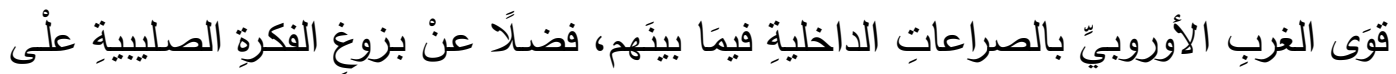
السطحْ بظهورِ الملكِ القبرصيِّ على مسرحِ الأحداثِ فيْ الغربِ الأوروبيِ.

( $\left.{ }^{1}\right)$ Raynaldi, Annales Ecc., T. 26, ann.1365, Nos.1, 2, pp. 104-105; Chaillan, Le Bienheureux, pp. 152-153; Persona, G., Cosmodromium, hoc est Cronicon vniuersale, complectens res Ecclesiae et reipublicae ab orbe condito usque ad annum Christi 1418, Francofurti, 1599, cap. 72-73, p. 248; Bréhier, Notre Dame de Doms, p. 73.

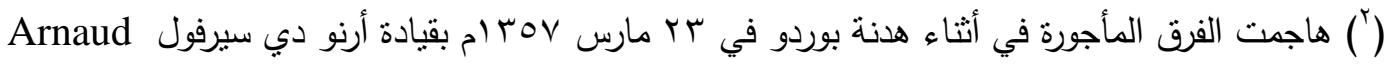

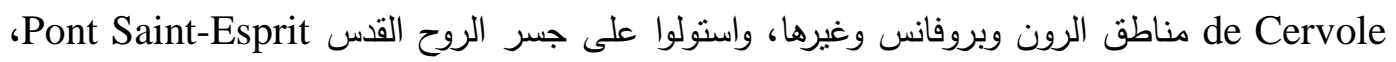

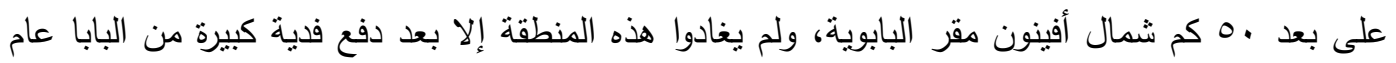

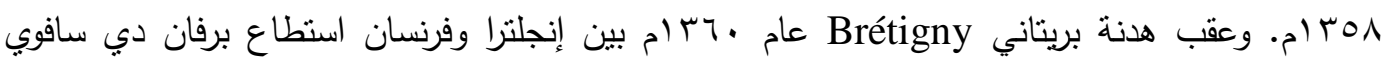
Pervin de Savoie

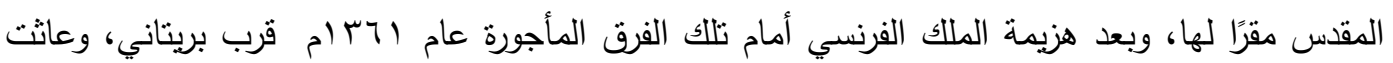
هذه الفرق فسادًا في أفينون وجنوب فرنسا؛ لذلك حاول البابا أوربان الخامس تجنيدهم في الحملات الصليبية

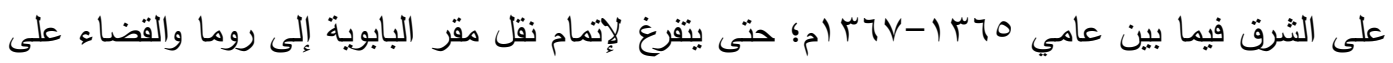

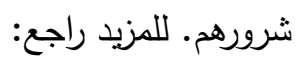

Raynaldi, Annales Ecc., T. 26, Ann.1365, N. 1, 2, pp. 104-105; Datta, P., Spedizione in Oriente di Amedeo VI. Conte di Savoia, Torino. 1826, pp. 13-15; Chevalier, U., Répertoire des sources historiques de moyen age, New York, 1960, V. I, p. 321; Denifle, La désolation des églises, T. II, pp. 188-211.

$\left({ }^{3}\right)$ Chaillan, Le bienheureux, pp. 152-153; Albanès, Vies antiques, pp. 70-71. 
ناثندتِ القديسةُ كاترينْ دِي سييناْ St. Catherine de Sienne (') الباباً بالعودةِ إلىى

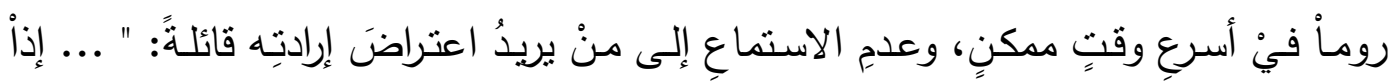

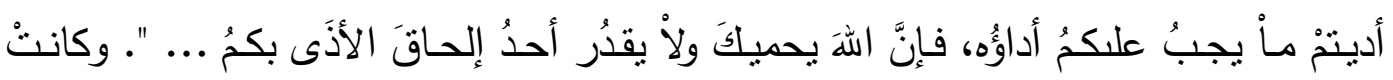

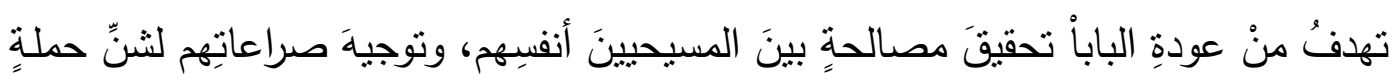

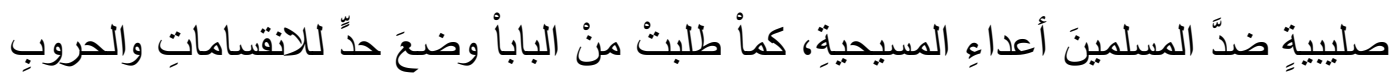

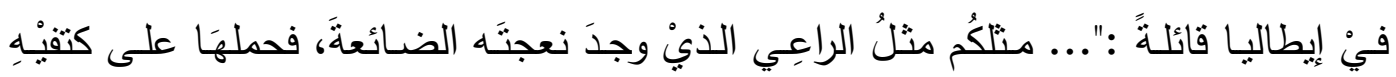

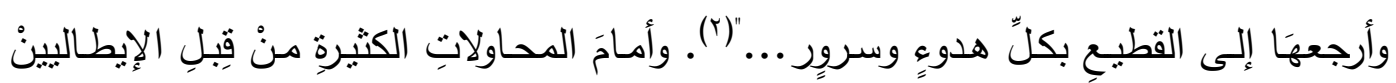

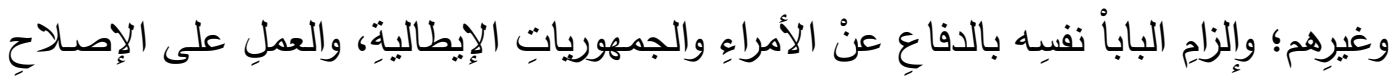

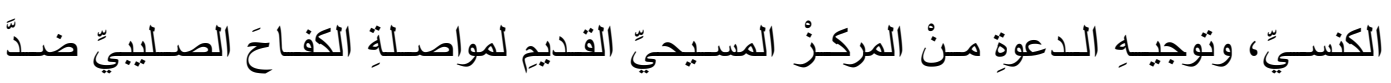

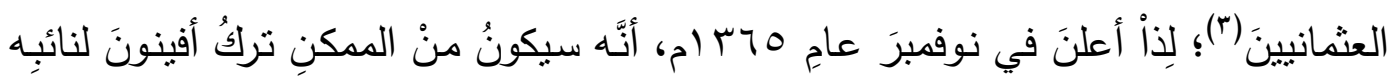

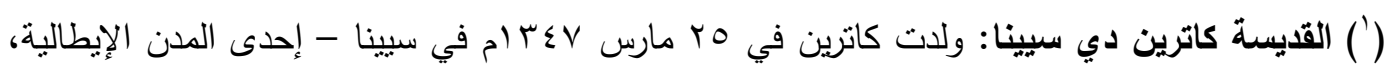
التي نسبت إليها - من عائلة بسيطة، فكان أبوها جياكومو بينينكازا Giacomo Benincasa-

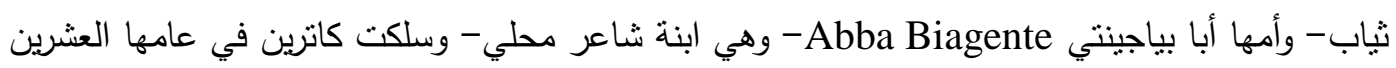

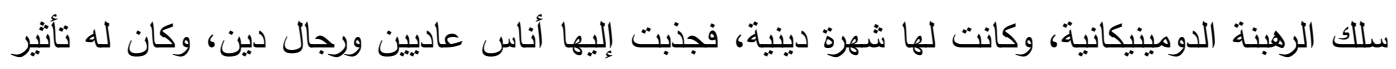

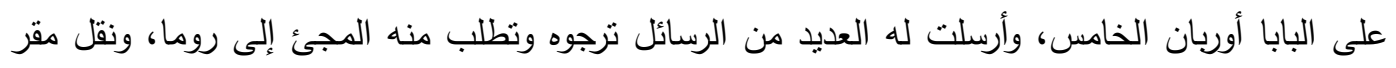

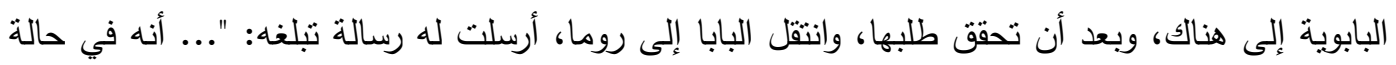

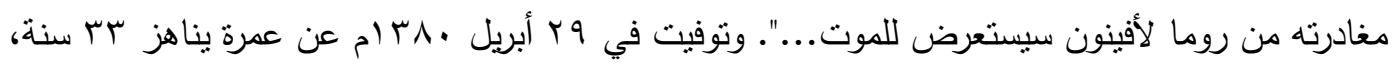

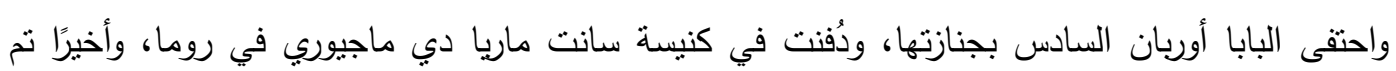

$$
\text { إعلانها قديسة عام اليانا آحان ام. للمزيد راجع : }
$$

Catherine de Sienne (Sainte), Lettres, trad. E.Cartier, éd. P. Tegui, pp. 7-8; Bouillet, Dictionnaire universel d'histoire, pp. 330, 1662; Encyclopadia universalis, Thesaurus. Index, Editeur à Paris, 1988, pp. 532-533.

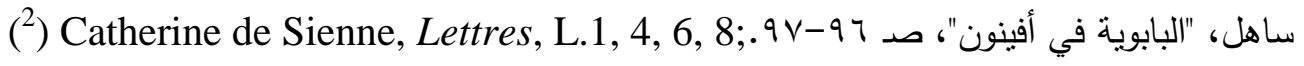

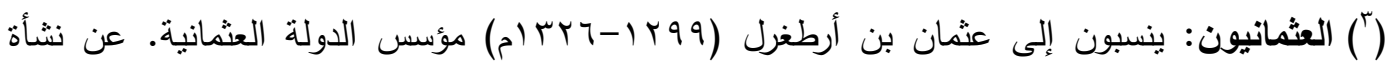

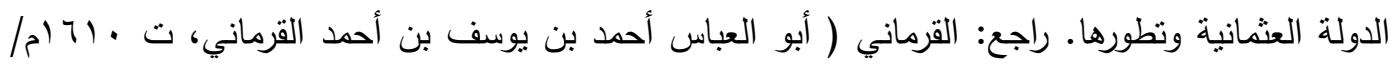

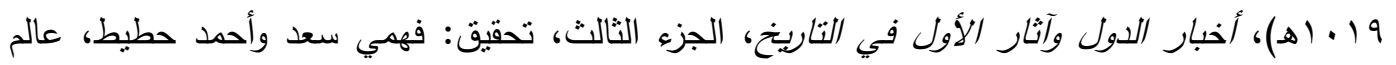

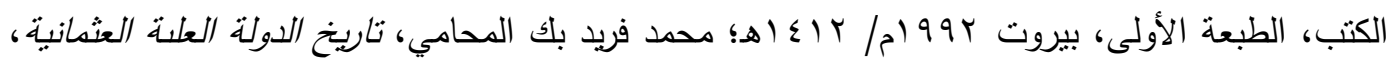

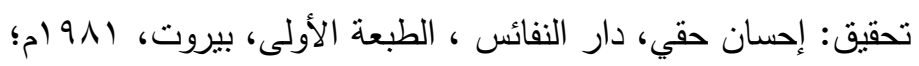
Collier, W. F., The Great Events of History, London, 1890, p. 174. 
والذهابُ إلى رومان، التيْ ستكونُ أكثرَ أمانَا منْ هُناً - يقصدُ أفينونَ- فيْ ظلِّ هجماتِ

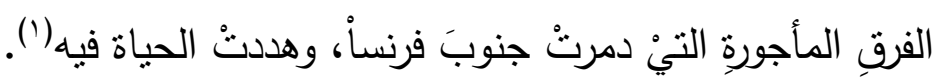

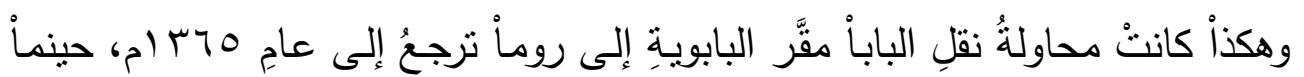

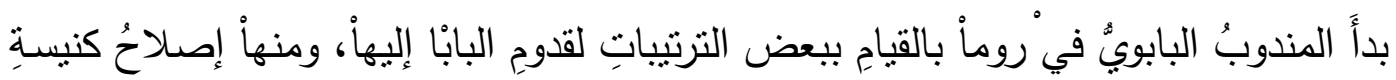

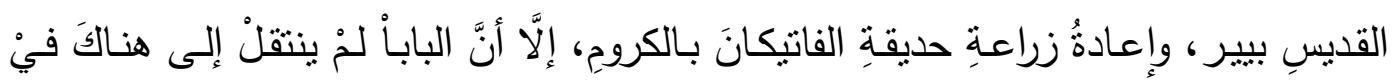
العامِ نفسِه لأسبابٍ: أولُها: انشغالُ الباباً فيْ الحملةِ الصليبيةِ ضدَّ العثمانيينَ الذينَ يهددونَ أراضيَ الإمبراطوريةِ البيزنطيةِ ودولِ البلقانِ، محاولًا توجيهِ الفرقِ المأجورة التيْ تسعى فسادًا

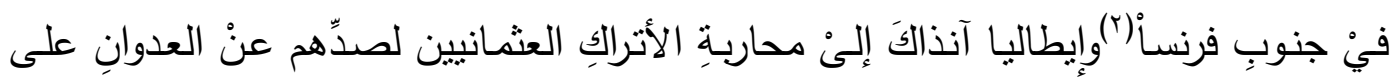
أراضِي الإمبراطورِ البيزنطيِّ(َ)، حنَّى يفي بوعدِه للباباً باعتناقِه للكاثوليكيةِ فيْ مقابلِ مساعدةِ

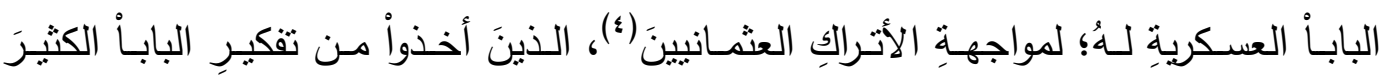

( $\left.{ }^{1}\right)$ Chaillan, Le bienheureux, pp. 152-153; Albanès, Vies antiques du pape Urbbain V, p. 103; Prou, Les relations politiques du pape Urbain V, p. 63; François, C., Histoire de tous les cardinaux François de Naissance, 2 Tomes,

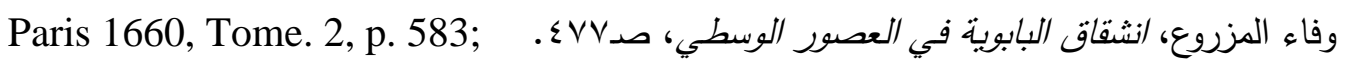

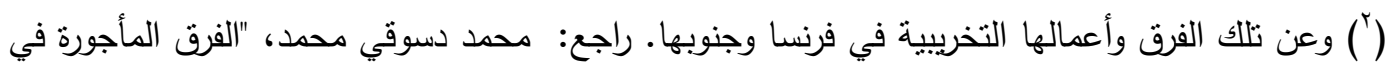

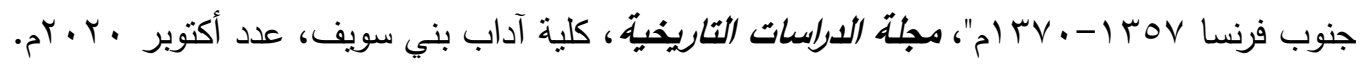

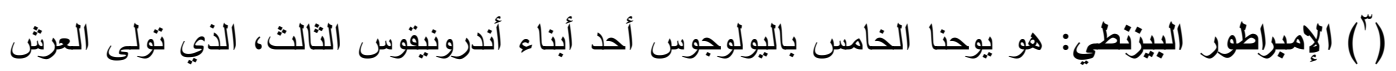

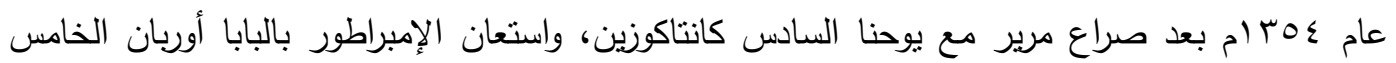

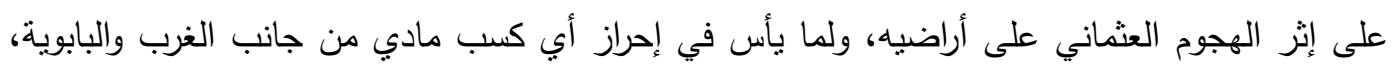

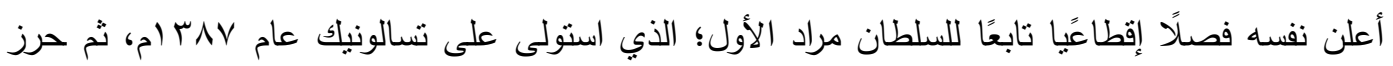

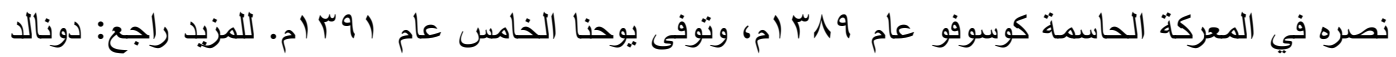

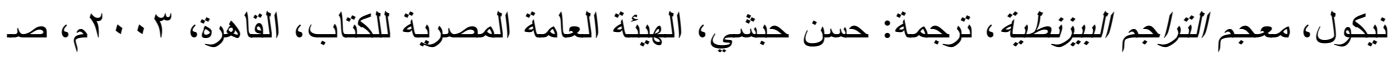
Charanis, P., "A Important Short chronicle of the Fourteenth century", 11 r -111 Byzantibion, Vol. XIII, Bruxelles. 1938, p. 344; Nicol, D. M., The Last Centuries of Byzantium, 1261-1453, London, 1972, pp. 191-197; Bréhier, L., Le monde byzantin: vie et morte de Beyonce, Paris, 1946, pp. 435-440; Hammer, J., Histoire de l'empire Ottoman, Trad. J.J. Heart, Tom. I, London, 1931, p. 179.

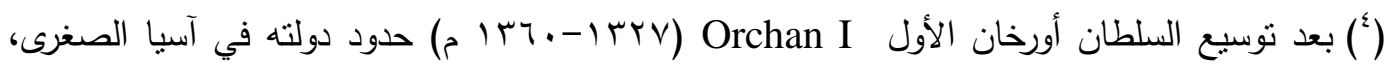
ونقل ميدان توسعاته إلى أوروبا، فامتلك العديد من القلاع في بلاد اليونان؛ لذا نجد البابا أوربان الخامس

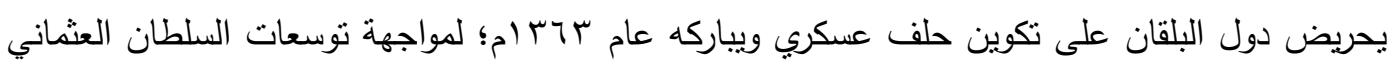

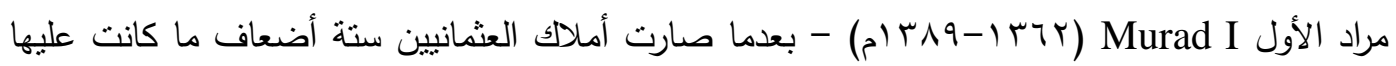
أيام جده عثمان، وبعدما تقدمت الجيوش العثمانية صوب نهر الدانوب، وحملت على أمراء البلقان؛ 
والكثيرَ (1)، ثانيًا: تركيزٌ جهود الباباً للاعوةِ للحملةِ الصليبيةِ بقيادةِ الملكِ القبرصيِّ بيير الأول (ץ) Pierre I الأوروبيِّ لتقديمِ المساعداتِ العسكريةِ والماليةِة للملكِ القبرصـيِّ(َ)، ثالثًا: اضطرابُ الأوضـاع

فتساقطوا واحداً تلو الآخر في قبضتهم - فكانت معركة ماريتزا الأولى عام سجس ام. راجع: القرماني، أخبار

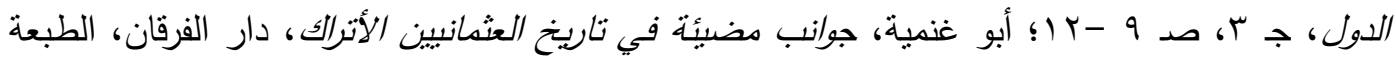

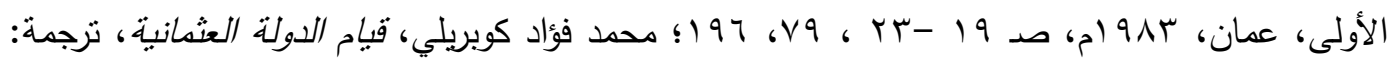
أحمد السعيد، دار الكاتب العربي، القاهرة، ب. ت، صـ .11 -11 إ أحمد عبدالرحيم مصطفى، أصول

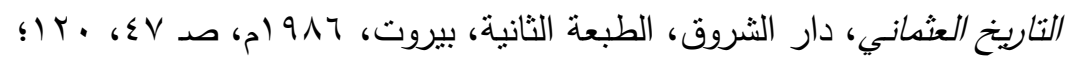
Gibbons, H. E., The foundation of the Ottoman Empire, Oxford, 1916, pp. 55 86; Collier, W. F., The Great Events of History, London, 1890, p. 174.

(') عن مساعدات البابا أوربان الخامس للإمبراطور البيزنطي العسكرية مقابل تخليه عن المذهب

$$
\text { الأرثوذكسي واعتناقه للمذهب الكاثوليكي. راجع: }
$$

Raynaldi, Annales Ecc., T. 26, ann. 1365, N. 22, pp. 120-121; Ann. 1366, N. 3, 4, pp. 122 - 125; ann. 1367, N. 7, 8, pp. 143-145; Ann. 1369, N. 5, p. 164; Tautu, L., Act Urbani V (1362-1370), Rome, 1964, N. 90, pp. 148 -149; N. 105, pp. 168169; N. 107, pp. 170-171; N. 129 A, pp. 207-209; Doukas M., Decline and Fall of Byzantium to the Ottoman Turks, London, 1975, pp. 84-86; Halecki, O., Un empereur de Byzance a Rome, Variarum Reprints, London, 1972, pp. 194-195.

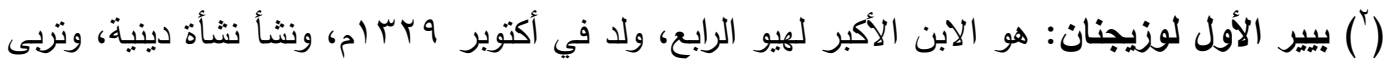

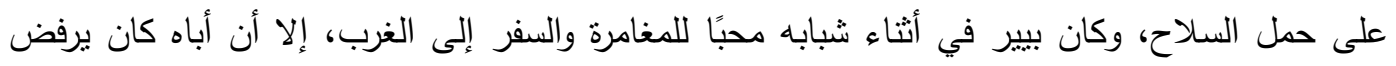

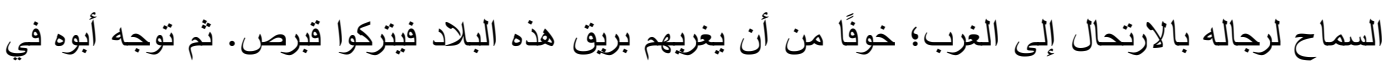
حياته، وأصبح كل اهنمامه ينركز حول القضاء على المسلمين. للمزيد راجع: Leonce Macheras, Chronique de Chypre, Traduction Francaise par E. Miller, Paris, 1882, pp. 48-52; Strambldi (Diamede), Chroiques de Strambldi, publiee par Rene de Mas Latrie, Paris, 1891, pp. 33-40; Fracois Amadi, Chroniques d'Amadi, publiee par Rene de Mas Latrie, Paris, 1893, p. 407.

(") وعن مساعدات البابا أوربان الخامس في الحملة الصليبية للملك القبرصي على الإسكندية عام 0بr ام، وجهود البابا في تكاليف الحملة وإعدادها. راجع:

Macheras, Chronique de Chypre, pp. 70-109, 115; Amadi, Chroiques d'Amadi, pp. 413-415; Machaut, G., La prise d'Alexandrie, publiee par Rene de Mas Latrie, Geneva, 1877, pp. 20-22, 117-120; Raynaldi, Annales Ecc., T. 26, ann. 1363, N. 25, p. 87; Atiya, A. S., The Crusade in the Later Middle ages, London,

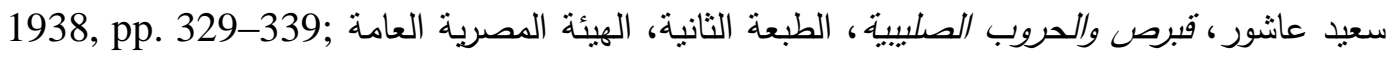

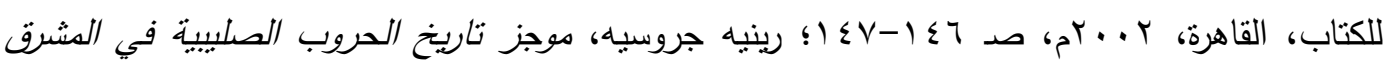

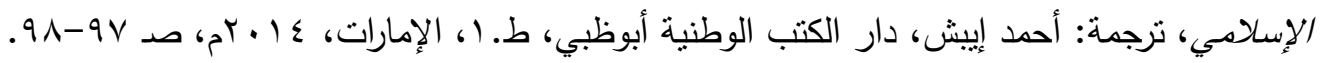




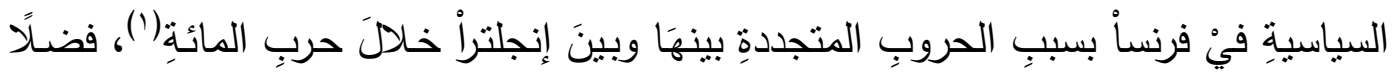

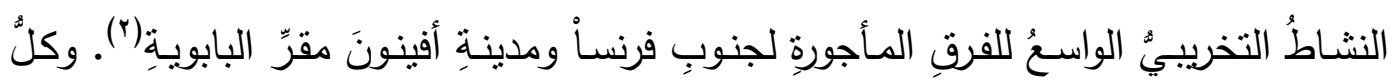

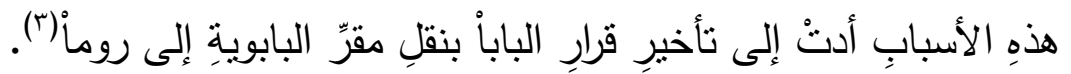

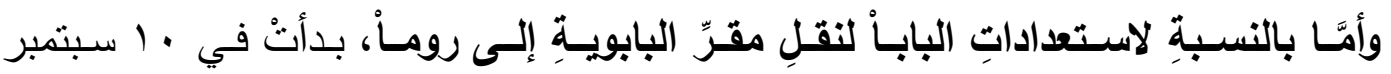

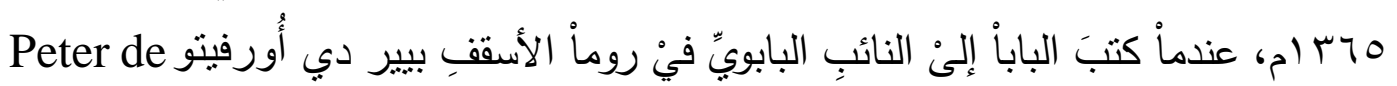
Orvieto

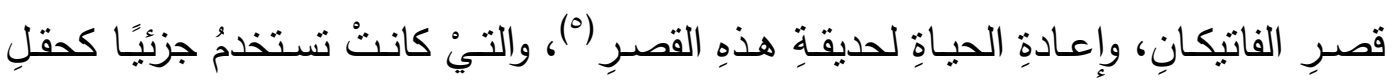
ومليئةة بالأشوالكِ، ويطلب كنهُ - نائبُه- فيْ رسالةٍ جديدةٍ بزراعةِ تللكَ الحديقةَ بالكروحِ وأثجارِ

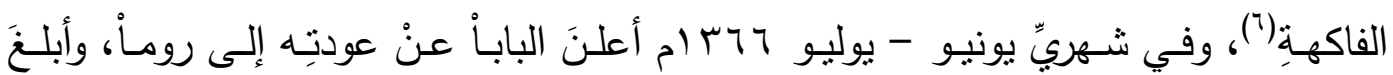

( $\left.{ }^{1}\right)$ Froissart, J., Chronicles of The England, France, Spain and the adjoining countries, London, 1901, V. 1, pp. 97-102; Burne, A. H., The Crecy War: Military History of the Hundred Years War from 1337 to the Peace of Bretigny 1360, Eyre \& Spottiswoode: 1955, pp. 67-240; Wagner, J., Encyclopedia of the Hundred Years War, London, 2006, pp. 38, 102-103; Villalon, A. L. J., "Spanish Involvement in the Hundred years war and the Battle of Najera", In H. Y. W. V. A. Kagay, Boston, 2005, pp. XXX III, 20-50.

( آ) للمزيد عن دور البابا أوربان الخامس تجاه تللك الفرق المأجورة وتوجهها للمحاربة ضد الأتراك العثمانيين

والمماليك في الثرق. راجع: 201-104-103 Chronographia regum Francorum (1270-1380), éd. H. Moranville, Paris, 1893, Tome 2, pp. 313-316; Denifle, H., la désolation des églises, pp. 449-450; Fréville R., Bibliothèque de l'École des Chartes, Tome 5, Paris, 1844, p. 241; Froissart, Chronicles of the England, Vol. 1, pp. 97-101; Michaud, Histoire des Croisades, p. 183.

( $\left.{ }^{3}\right)$ Setton, K. M., "The Papacy and the Levant, 1204-1571", In The thirteenth and fourteenth centuries, Vol. I, American Philosophical Society, 1976, pp. 177-178. (أ) أورفيتو: بلدة إيطالية في مقاطعة تيرني Terni، أوميريا Umbria، وتقع على صخرة بالقرب من باغليا Paglia، وتبعد حوالي 7 كيلو متر شمال غرب روما Pome. وشيد بها القصر البابوي Palazzo. Moore, The Penguin خلا القرنين الثالث عشر/ الرابع عشر الميلادي. راجع: Papale Encyclopedia, p. 586; Bouillet, Dictionnaire universel d'histoire, p. 1319.

(") وكانت مزرعة الكروم والحديقة في قصر الفاتيكان، والتي تم وضعها تحت إثراف مستشار روما يوحنا سينسي Johannes Cenci، هي نفسها التي كان يدور في ذهن البابا في الرسالة السابقة، فقد تم تتفيذ هذا

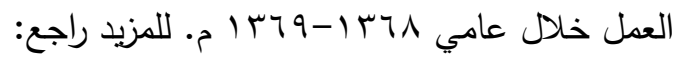

Kirsch, Die Ruckkehr der Papste Urban V, p. X; Pastor, Histoire des papes, p. 112.

( $\left.{ }^{6}\right)$ Theiner, A., Codex diplomaticus., T. II, N. 408, p. 405; Kirsch, Die Ruckkehr der Papste Urban V, p. X. 
الكاردينالَ ألبورنوزَ بتهيئةِة القلعِة التيْ بناهاً فيْ فيتربو Viterbo(')؛ للإقامة فيهاْ أثناءَ رحلته

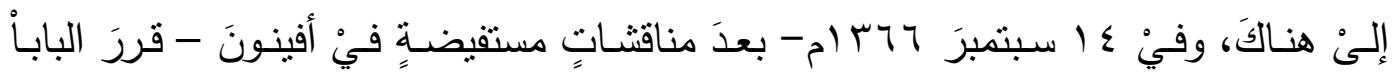

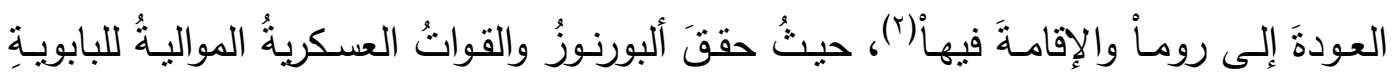

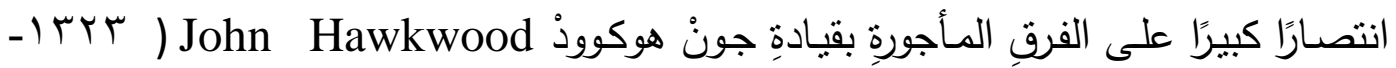

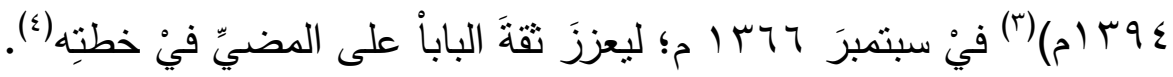

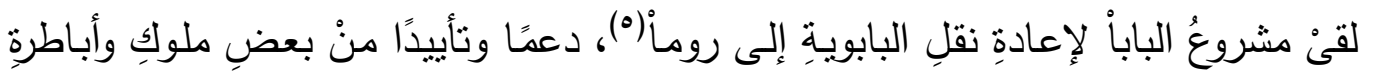

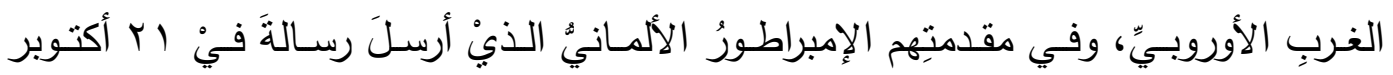

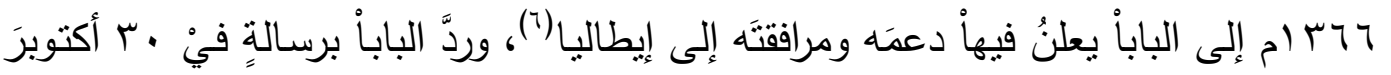

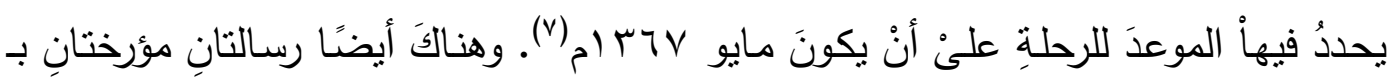

(') فيتريو: مدينة إيطالية، عاصمة مقاطعة فيتربو Viterbo، وتقع شمال وشمال غرب روما Rome، وكال

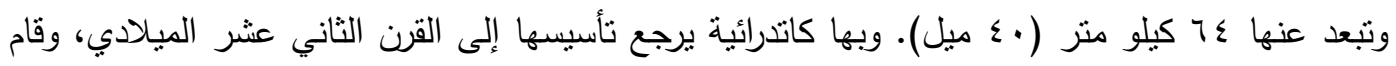
البابا أدريان الرابع Adrian IV (نيقولاس بريكسبير Nicholas Breakspear) بفرض تكريم الإمبراطور

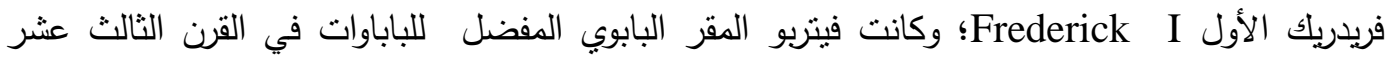
الميلادي. راجع: Moore, The Penguin Encyclopedia, p. 837; Bouillet, Dictionnaire universel d'histoire, p. 1718.

$\left(^{2}\right)$ Muratori, L.A., Annali d'Italia dal principio dell'era volgare sino all'anno 1750, Tome. 8, Lucca, 1763, p. 265; Chaillan, Le bienheureux, pp. 152-153; Raynaldi, Annales Ecc., T. 26, ann. 1365, n. 9-10, p. 108; Christophe, Histoire de la papauté, T. 2, pp. 366-367.

(r) جون هوكوود: ولد في إسكس عام بr إم، وهو الابن الثاني لجيلبرت هوكوود، وهو أحد النبلاء،

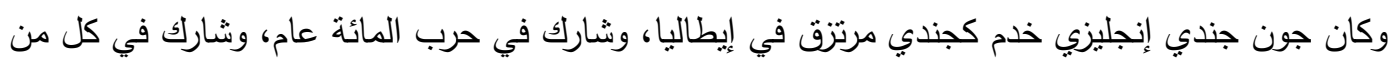

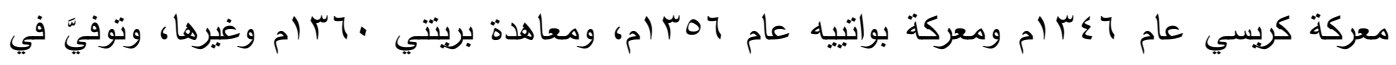

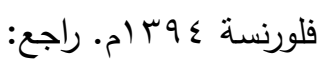

Bouillet, Dictionnaire universel d'histoire, pp. 411, 416; Caffiero, W., John Hawkwood: An English Mercenary in Fourteenth-Century Italy. Baltimore: Johns Hopkin University Press, 2006, pp. 5-20.

$\left({ }^{4}\right)$ Christophe, Histoire de la Papauté, T. 2, p. 374; Froissart, J., Les Chroniques,

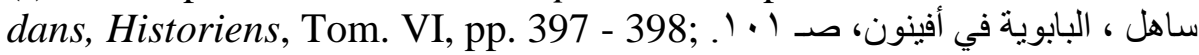

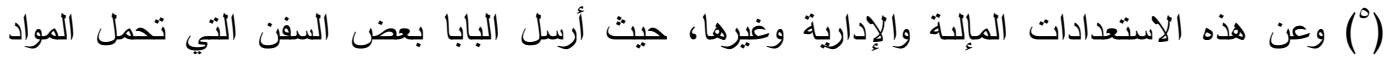
الغذائية مثل النبيذ والأسماك وغيرها، كما عمل البابا على نسخ الكثير من سجلات أفينون ولنقلها إلى روما. كما تلقى المسؤولون في الإدارات المختلفة في الغرفة الرسولية مبالغ معينة لتغطية نفقات النقل. للمزيد

Kirsch, J. P., Die Ruckkehr der Papste Urban V., pp. X - XIIV. راجع:

$\left({ }^{6}\right)$ Baluzius, Vitae paparum avenionensium, T. 1, pp. $400-402$.

( ${ }^{7}$ ) Raynaldi , Annales Ecc., T. 26, ann. 1366, N. 26, pp. $136-137$. 


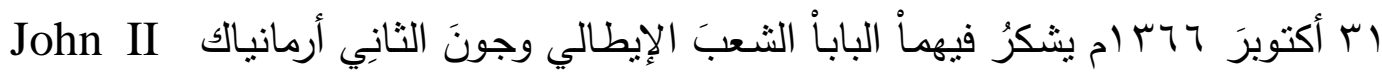

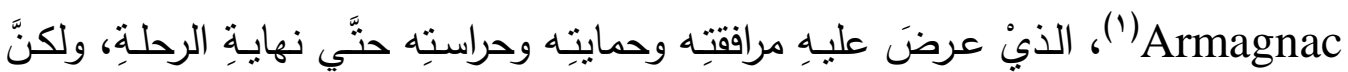

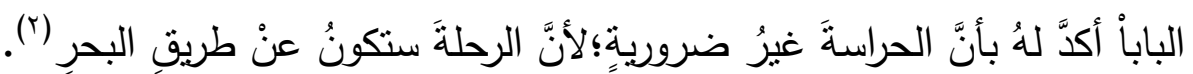

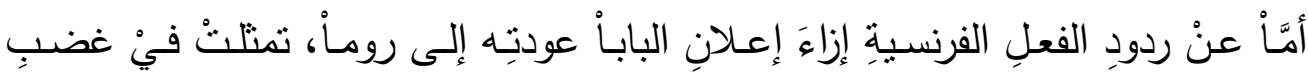

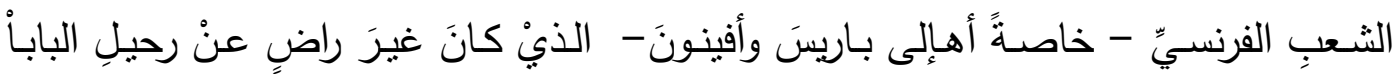

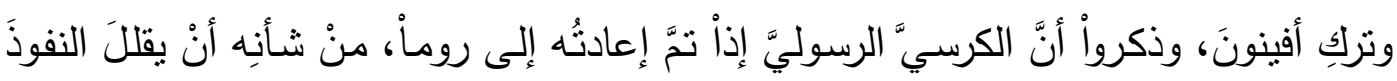

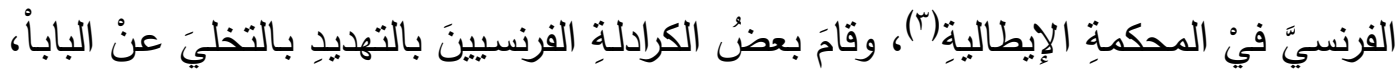

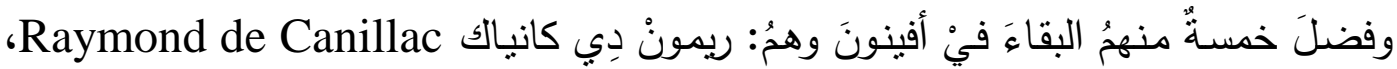
وبيير دِي مونتري Pierre de Manterue، وبيير إيتيّ Pierre Itier، إيلي دي سانت يريكس Élie de Saint-Yrieix، وجون دي بلوزاك Jean de Blauzac، حيثُ تذرعواً

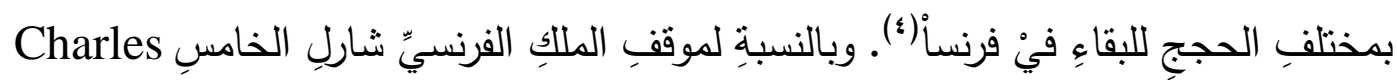
Charles V V

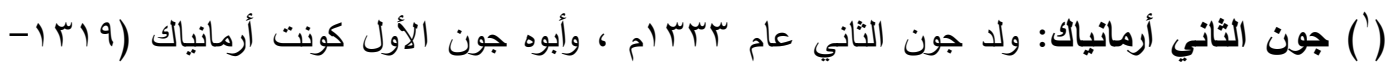

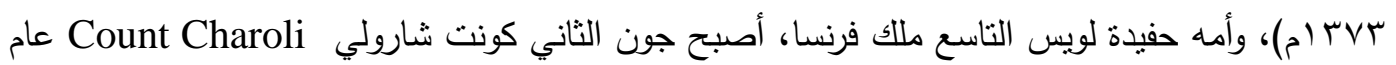
ع צrام في حياه أبيه، ثم صار بعد وفاه أبيه كونت أرمانياك Count de Armagnac

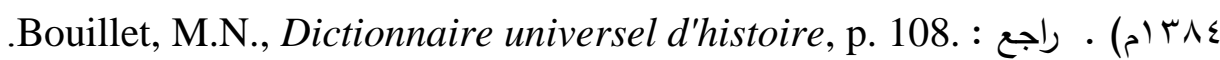
$\left(^{2}\right)$ Chaillan, Le Bienheureux, pp. 152-154; Baluzius, Vitae paparum, T. 1, pp. 400 -402 .

$\left({ }^{3}\right)$ Hefele C., Histoire des Conciles d'après les documents Originaux, traduite de l' Allemand par M. L'Abbe Delarc, Tome .9, Paris 1873, pp. 597-599; Chaillan, Le Bienheureux, pp. 152-153.

$\left.{ }^{4}\right)$ Hayez , M., Avignon sans les Papes (1367-1370, 1376-1379), dans Genèse et débuts du Grand Schisme d'Occident, éd., C.N.R.S, Paris, 1980, p. 144 ; ساهل

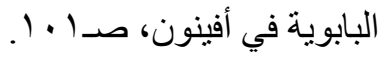

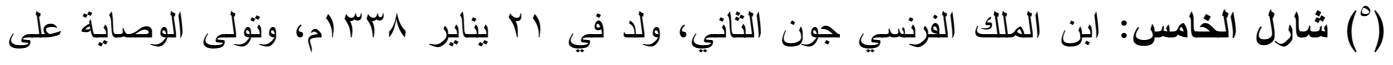

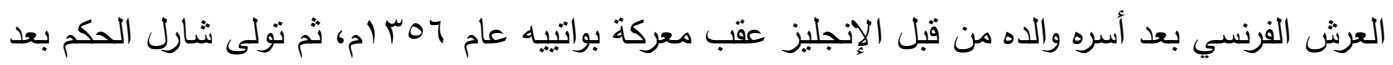

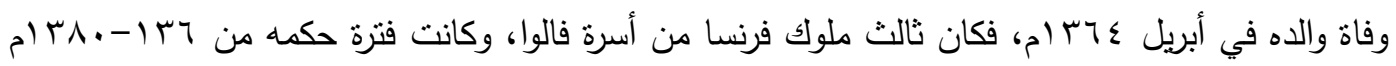

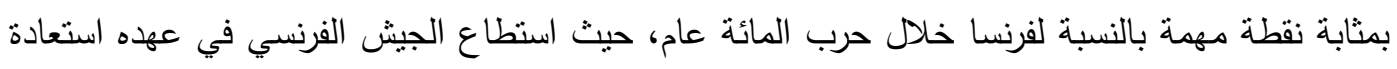

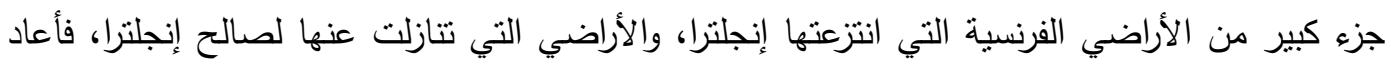

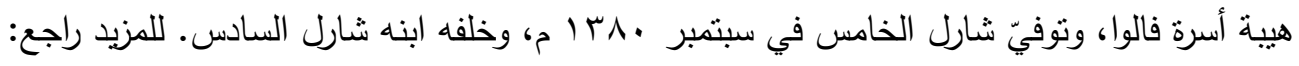
Delachenal, R., Histoire de Charles V, Tomes. 3, Paris .1916, pp. 20-267; Prou, M., Etude sur les relations, pp. 20-90; Bouillet, M. N., Dictionnaire universel d'histoire, pp. 354-355. 
نكراء نَتبهُ الهزيمةً التيْ تعرضتْ لهاُ القواتُ الفرنسيةُ فيْ كريبِي Crecy (')؛ لذاْ أرسلَ سفارةً

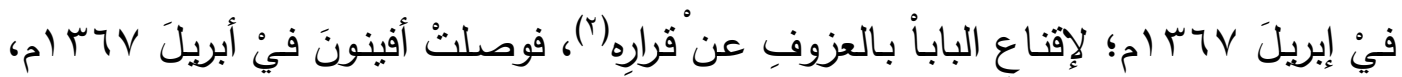

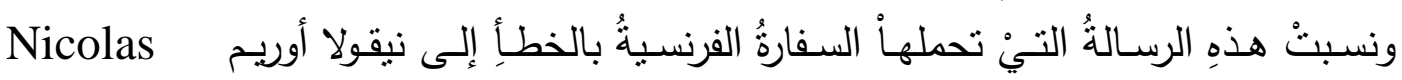

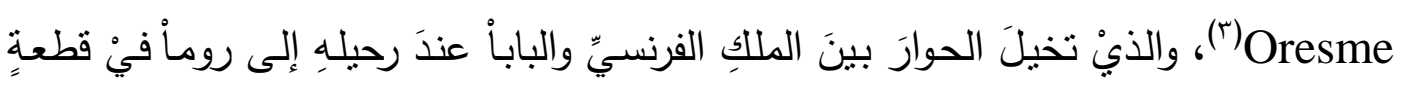

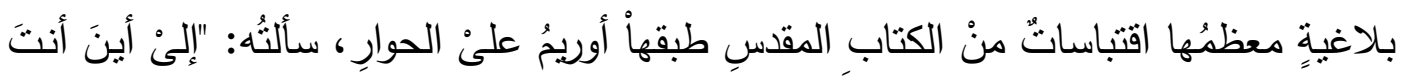

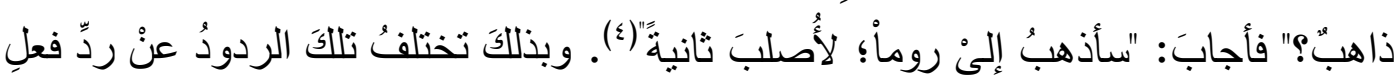

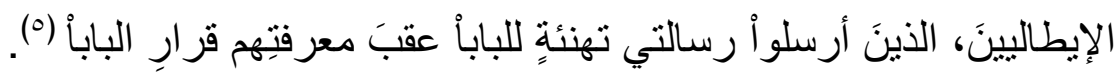

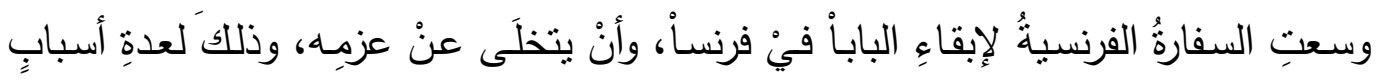

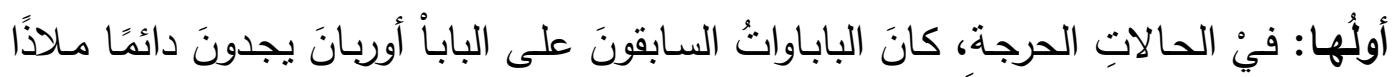

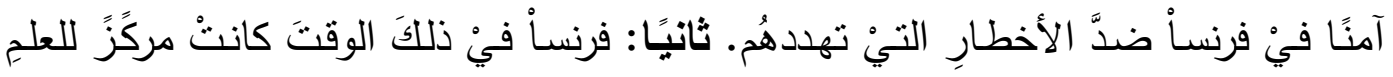

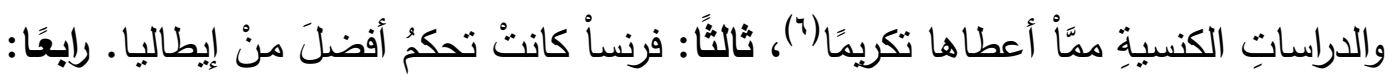

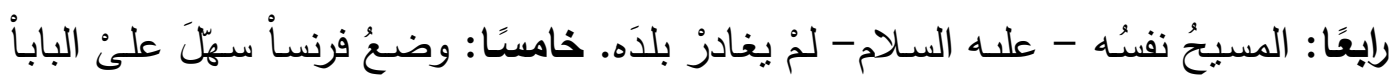

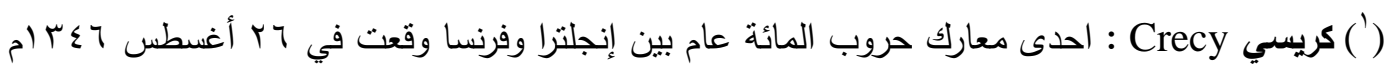
قرب مدينة كريسي الحالية، وانتهت بهزيمة الجيش الفرنسي على يد الجيش الإنجليزي على الرغم من قلة النة

$$
\text { عدد الجيش الإنجليزي. للمزيد راجع: }
$$

Burne, The Crecy War: Military History of the Hundred Years War, pp. 66-243; CF. A.Ayton, Ph. Preston, The Battle of Crécy, 1346, Boydell Press, 2005. (') وكانت تلك السفارة تتكون من الكونت بيير دوينامب Come Pierre de Etampes، وليم دي دورمان William de Dormans وبيير دي فيلير Pirerre de Villers ونائب الملك الفرنسي، ودوق برجنديا

$$
\text { Burgundy }
$$

H. Albanès, Vies antiques du pape Urbbain V, pp. 75 - 76; Christophe, Histoire de la Papauté, T. 2, pp. 363 - 364.

(") وهو رسول الملك الفرنسي شارل الخامس إلى البابا أوربان الخامس، عندما علم بعودة البابا إلى روما؛

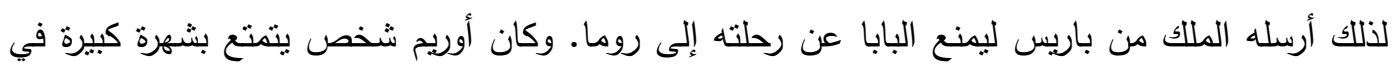

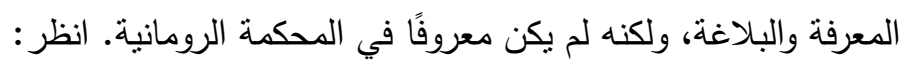

Christophe, Histoire de la Papauté, T. 2, pp. 363-364.

$\left({ }^{4}\right)$ Prou, M., les relations politiques du pape Urbain V., pp. 63-66; J. H, Albanès, Vies antiques du pape Urbbain V, pp. 75 - 76; Christophe, Histoire de la Papauté, T. 2, pp. 363 - 364.

${ }^{5}$ ) Theiner, A., Codex diplomaticus. , T. II, N. 419, 420, P, 439; Kirsch, J. P., Die Ruckkehr der Papste Urban V., p.XII.

$\left.{ }^{(}{ }^{6}\right)$ Bouillet, Dictionnaire universel d'histoire, p. 314. 


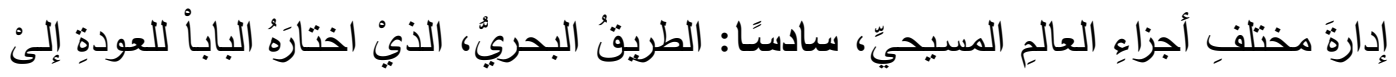

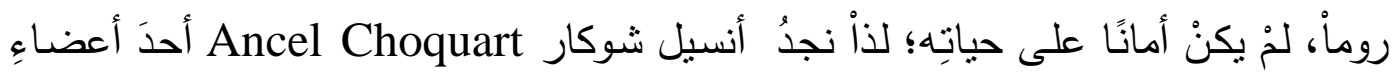

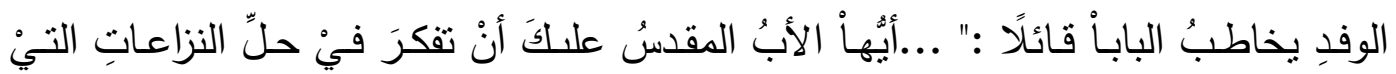

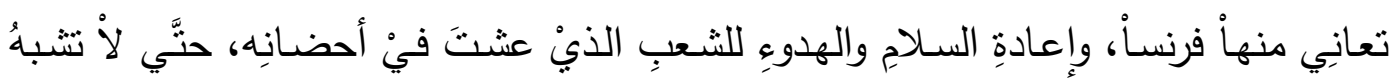

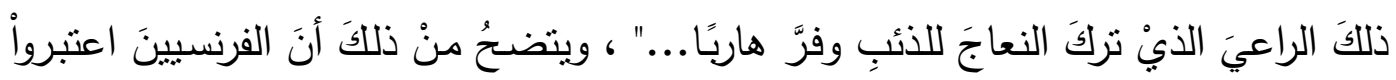

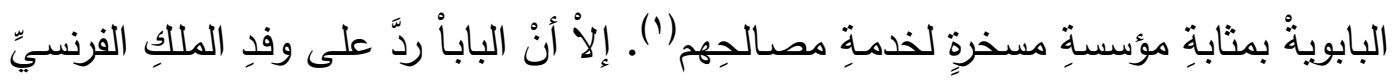

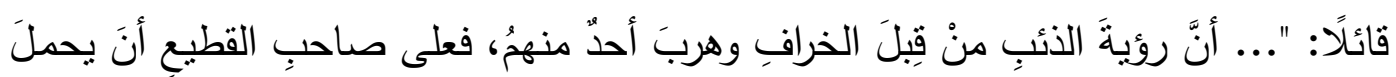

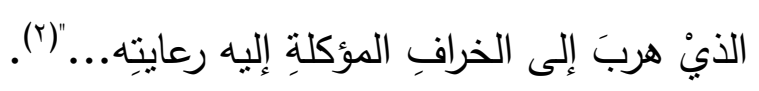

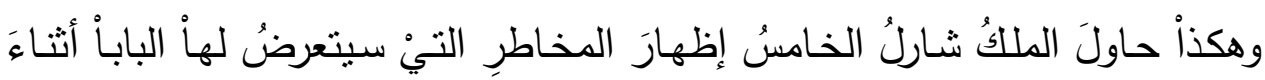

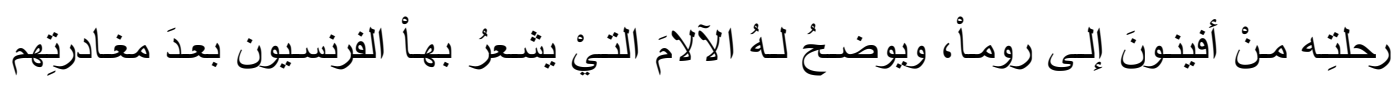

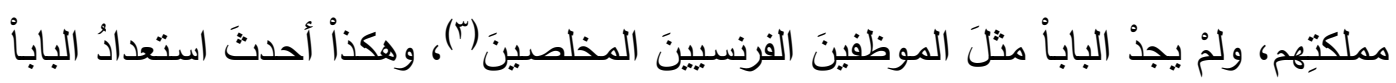

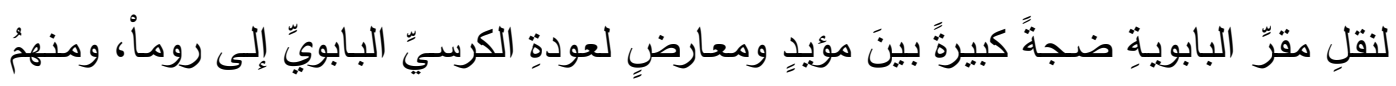

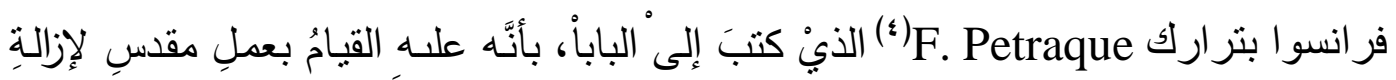

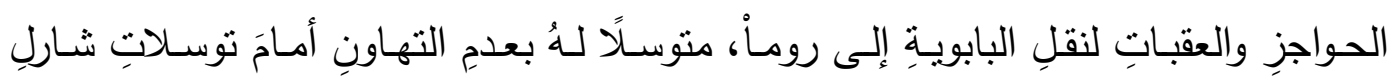

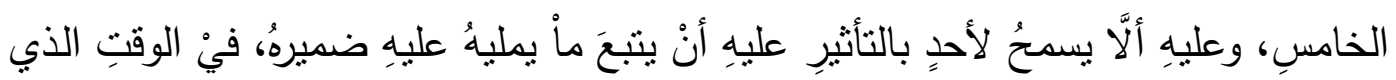

( $\left.{ }^{1}\right)$ Delachenal, Histoire de Charles V , T. 3 , pp. 515-523; Charles Poulet, Guelfes et Gibelins, Vromant, Bruxelles, 1922, Tome 2, p. 211; Christophe, Histoire de la Papauté, T. 2, pp. 369 - 370.

$\left.{ }^{2}\right)$ Chaillan, Le Bienheureux, pp. 154-155; F. Emule, Historia Bibliothecae Romanorum Pontificum, Rome, 1890, pp. 63 - 64.

$\left(^{3}\right)$ Prou, Les relations politiques du pape Urbain V, pp. 65-66; Chaillan, Le Bienheureux, pp. 152-153; Christophe, Histoire de la Papauté, T. 2, pp. 360 361.

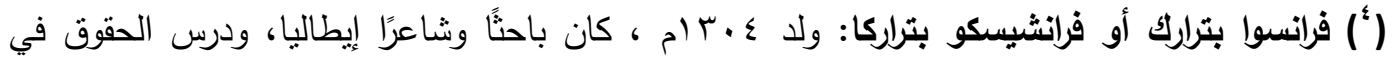

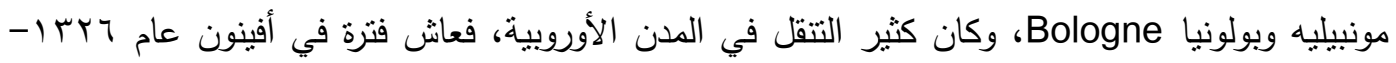

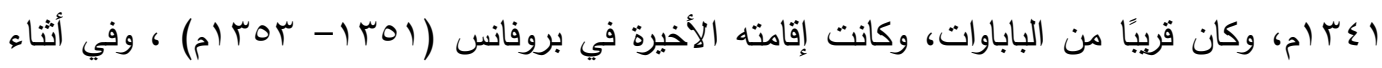

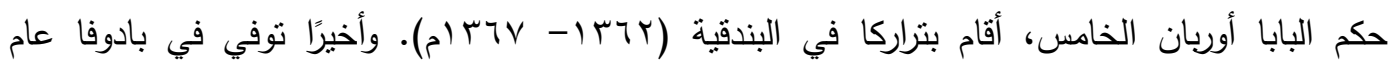

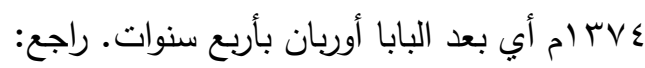

Sara Sturm-Maddox, Petrarch's Laurels, Pennsylvania State University Press. 2010, pp. 80,153- 200; Moore, The Penguin Encyclopedia, pp. 48,111 


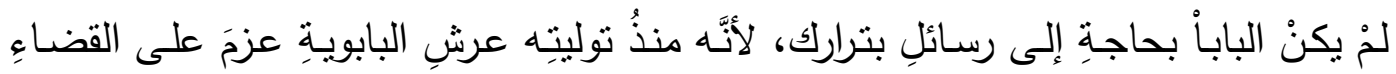

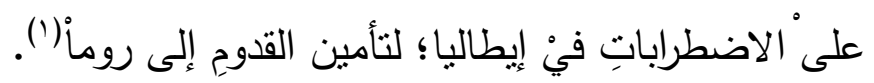

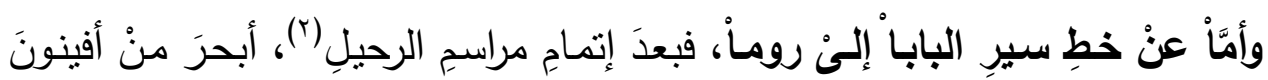

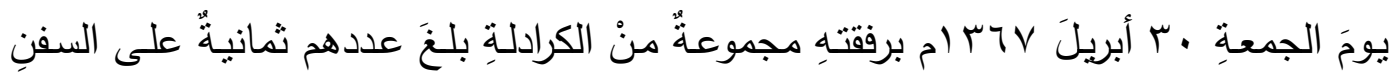

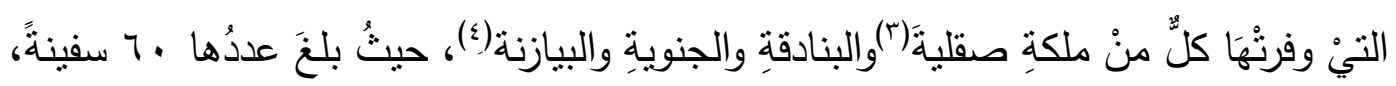

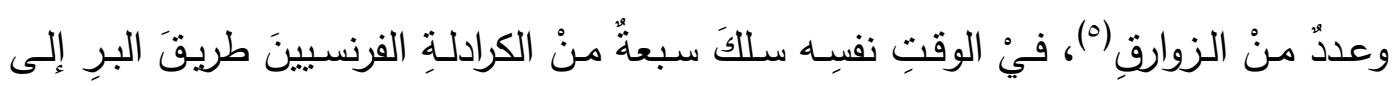

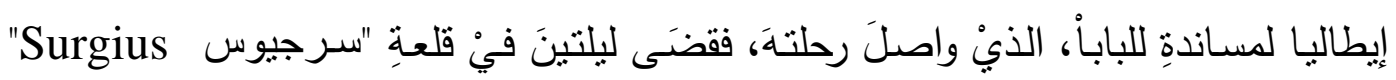

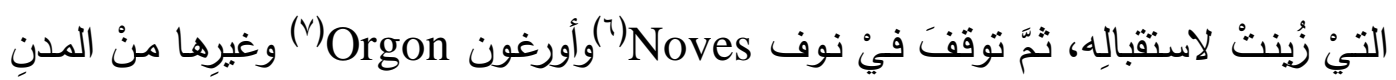

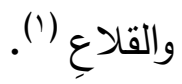

( $\left.{ }^{1}\right)$ Chaillan, Le Bienheureux, pp. 154-155; Prou, Les relations politiques du pape Urbain V., pp. 65-66; Albanès, Vies antiques du pape Urbbain V, pp. 70-71; Christophe, Histoire de la papauté, T. 2, pp. 366-367; Muratori, Annali d'Italia, T. 8 , P. 265; Chronicon, Veterum scriptorum et monumentorum historicorum, T. V, Paris .1729, p. 281.

( $\left.{ }^{2}\right)$ Homo, L., Rome Medieval, 476-1420, Paris, 1956, p. 218; Mollat (G.), Samaran (Ch.), La fiscalité pontificale en France au XIVème siècle, Thorin et fils,

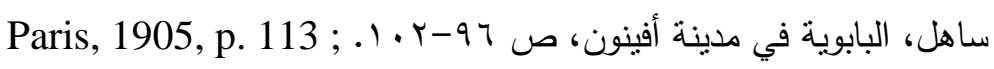
(") جزيرة صقلية: إحدى الجزر القريبة من إيطاليا، يكثر بها الضياع وأعمالها كبيرة وبلادها كثثرة. راجع،

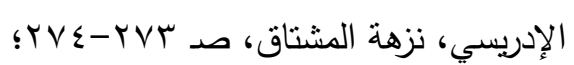

Moore, The Penguin Encyclopedia, pp. 718-719.

( ) أ) وكان هناك تتافس كبير بين الددن البحرية الإيطالية لتزويد البابا في أثناء رحلته بشتى الوسائل التي

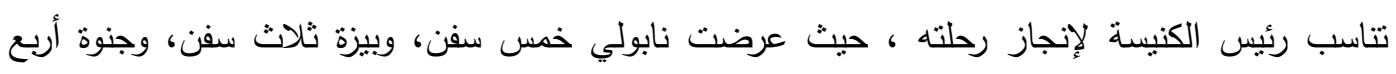

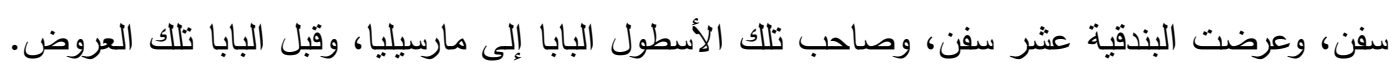

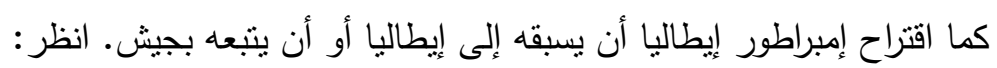

Raynaldi, Annales Ecc.,.T. 26, ann. 1366, N. 26, pp. 136-137; Kirsch, Die Ruckkehr der Papste Urban V., pp. XI-XII; Christophe, Histoire de la papauté, T. 2, pp. 367-373.

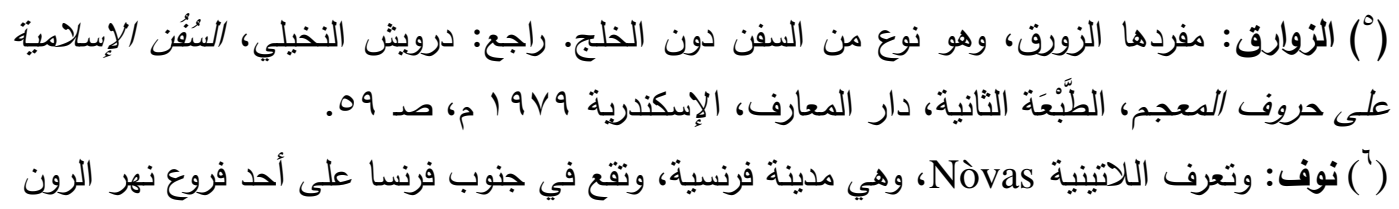

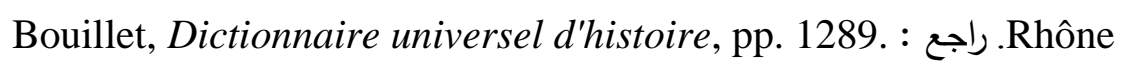
( أوغون: هي بلدة تقع في مدينة آرل Arles، الواقعة في جنوب فرنسا، وتضمن مدينة آرل ثماني

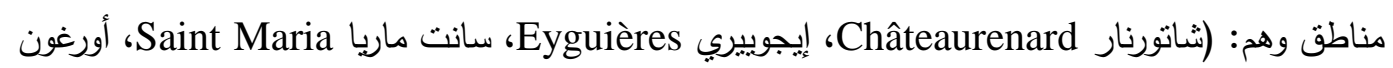

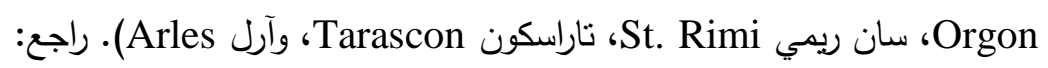


وصلَ الباباً إلى مارسيلياً فيْ 7 مايو Vד T ام، ومنهاْ اتجهَ إلى ديرِ القديسِ فيكتور St.Victor

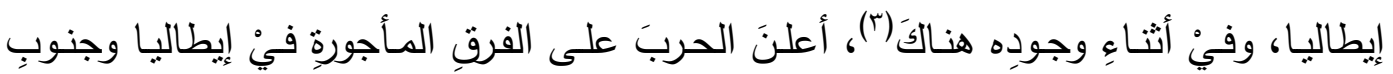

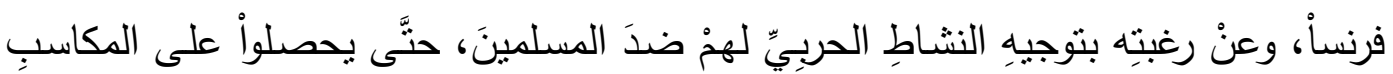

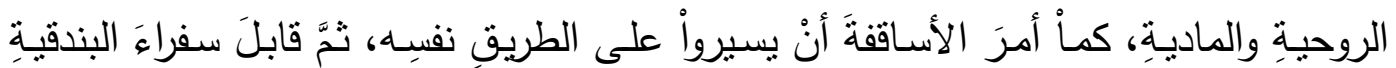

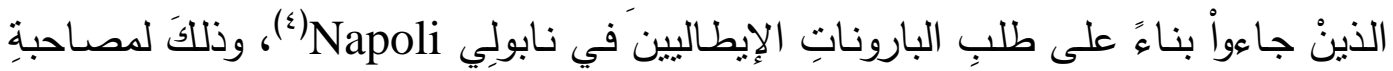

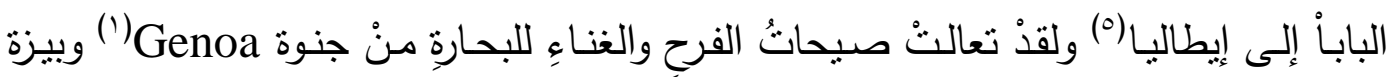

Bouillet, Dictionnaire universel d'histoire, pp. 99, 108.

( $\left.{ }^{1}\right)$ Raynaldi, Annales Ecc.,T. 26, ann. 1366, N. 26, pp. 136-137; Chaillan, Le Bienheureux, pp. 156-157; Baluzius, Vitae paparum, T. 1, pp. 385-386; Prou, Les relations politiques du pape Urbain V., p. 68; Hefele, Histoire des Conciles, T. 9, pp. 598-599; Mollat, La Fiscalité pontificale en France, p. 113;

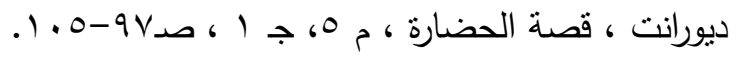

(') دير سانت فيكتور: نم تأسسه في القرن الخامس الميلادي على يد القديس كاسيان Cassien، ويقع

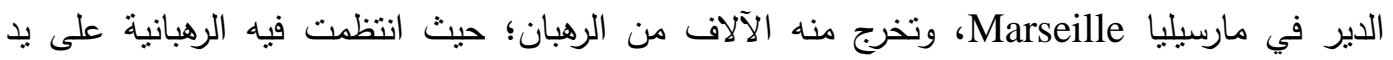

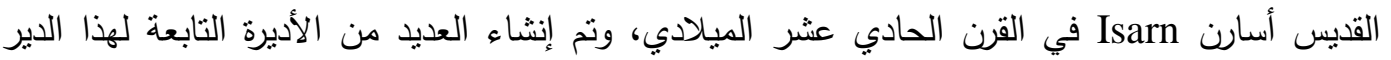

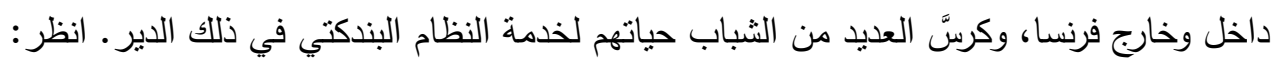
Chaillan, Le bienheureux, pp. 7-10.

(") ولقد أمر البابا بإعادة ترميم ما تهدم من هذا الدير من الجدران والأبراج، ومنحه امنبازات واسعة،

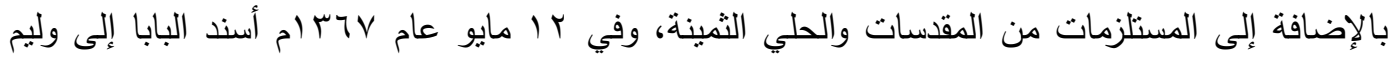
دي أجريفوليو Guillelmum de Agrifolio مهمة الكاردينال، ثم كاتب العدل للكرسي الرسولي على وفي الرغم من صغر سنه ، فلم يتجاوز عمر ب سنة .للمزيد راجع: Albanès, Vies antiques du pape Urbbain V., p. 17; Kirsch, Die Ruckkehr der Papste Urban V., pp. X-XII. (") نابولي: أو نابولس Neapolis قديمة، وهي مدينة إيطالية، عاصمة إقليم نابولي، وثاني موانئ إيطاليا-

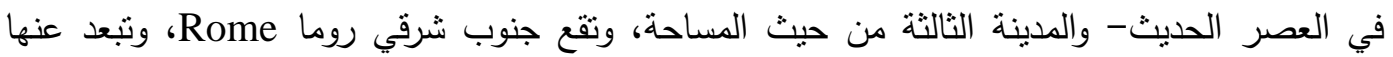
بوا كيلو متر • راجع : بنيامن التطيلي، الرابي بنيامين بن يونه التطيلي النباري الأندلسي، رحلة بنيامين

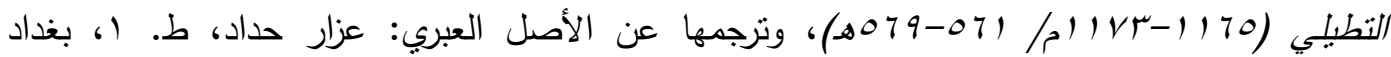

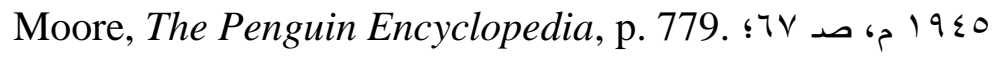

$\left(^{5}\right)$ Chaillan, Le Bienheureux, pp. 158 - 160 ;M. Simeon, Chronique des quatre premiers valois (1327-1393), Paris. 1861, pp. 182-183; Baluzius, Vitae paparum, Tome 1, pp. 385 - 386; J. H, Albanès, Vies antiques du pape Urbbain V, pp. 16 17; Rohrbacher (R.F.), Dufour (A.H.), Histoire universelle de l'Eglise catholique, Tome. 20, Paris, 1938, pp. 390 - 391. 
Pisa

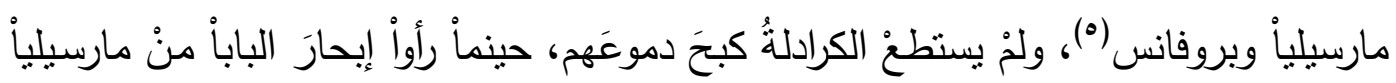

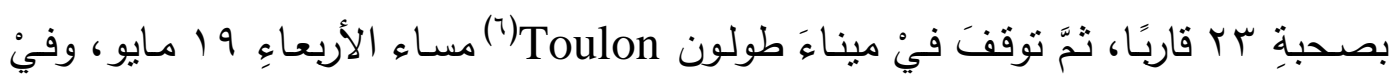

(') جنوة Ganoa: مَدِينَة إيطإلِة نطل على البَحْر المتوسط، عاصمة ليغوريا Liguria مقاطعة جنوة، وبها بسانتين من الفواكه، وبها مرسي جيد مأمون. ودخلت جنوة مع الجمهوريات الإيطالية في مجال النّجَارَة،

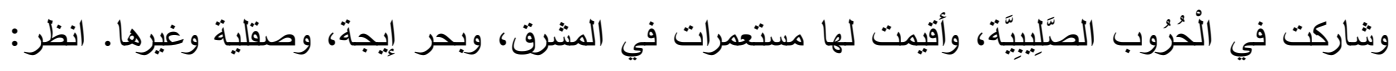

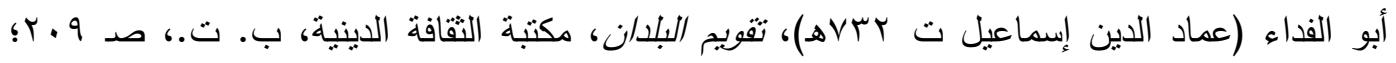

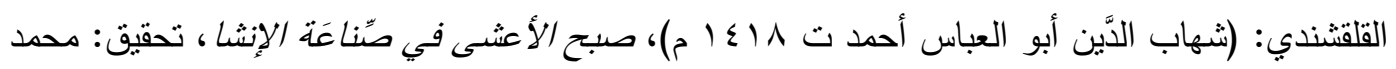

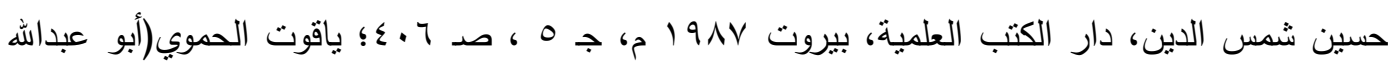

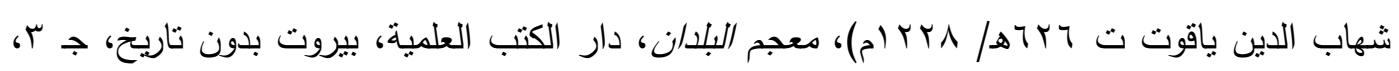

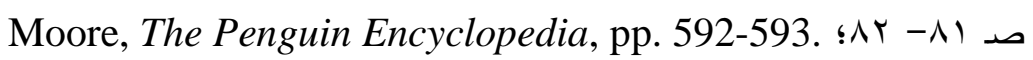

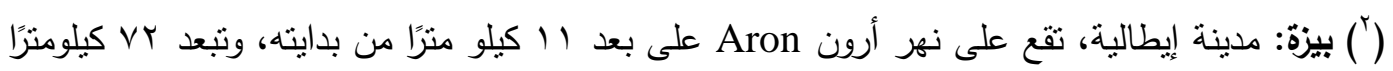

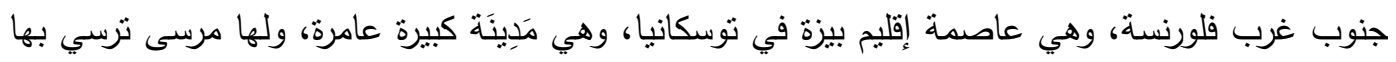

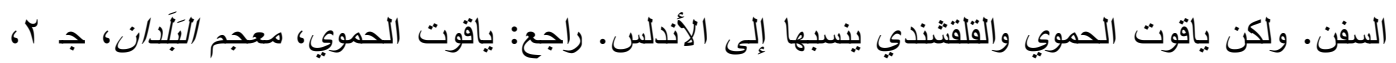

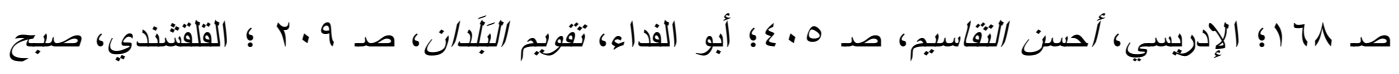

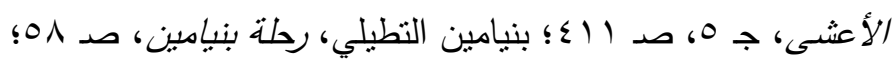

Moore, The Penguin Encyclopedia, p. 617..

(r) فلورانسا: مدينة إيطالية، عاصمة إقليم نوسكانيا، تقع على نهر الأرنو Arno في موقع متميز شمال

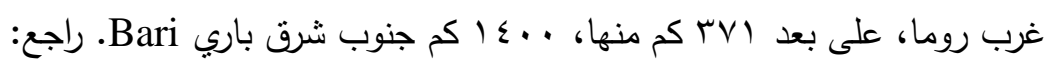

Najemy, M. J., History of Florence 1200-1575, London, 2006, pp. 5-211; Bouillet, M. N., Dictionnaire universel d'histoire, p. 673; Moore, The Penguin Encyclopedia , p. 281.

(4) أنكونا: تعرف عند الإدريسي باسم أنكلون، وهي مدينة إيطإلنة، تقع شرق روما على البحر الأدرياتيكي Adriatic Sea

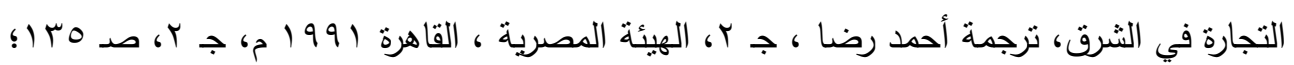
Bouillet, Dictionnaire universel d'histoire, pp. 74 -75.

( ) حيث رفض بعض الكرادلة الفرنسيين اتباع البابا ، ومنهم كانياك Canillac وبلادياك Bladiac Prou, les relations politiques du pape Urbain V., P. 68; Hefele, Histoire des conciles, T. 9, pp. 598-599.

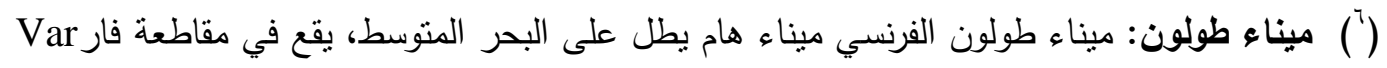
على بعد V S S (9 ميل) شرق وجنوب شرق مارسيليا، وهو ميناء لبناء السفن وصلاحها.راجع: Moore, The Penguin Encyclopedia, p. 790. 
اليوِ التالي واصلَ رحلتَه، حنَّى ميناءَ أوليفي Oalivet Port (')، بالقربٍ منْ نيس Nice)

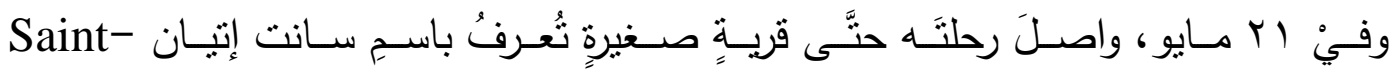
Etienne

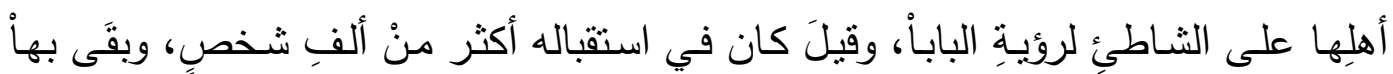

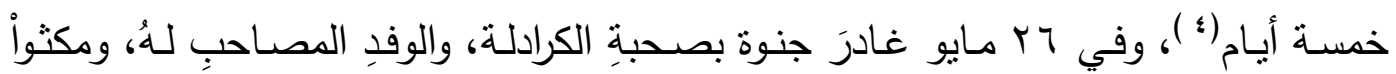

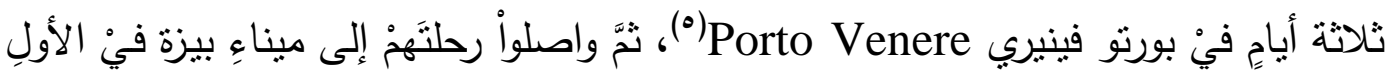

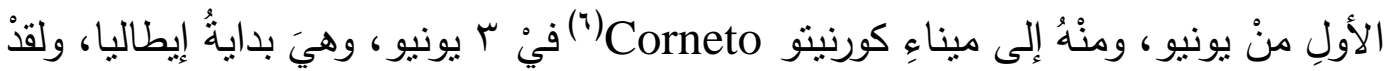

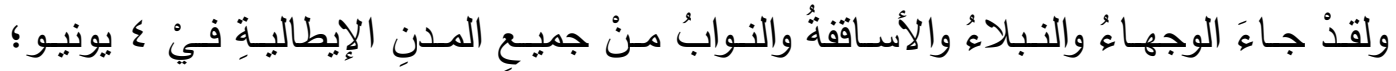

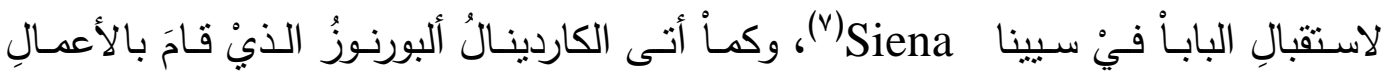

(') ميناء أوليفت: يقع في مدينة أوليفي Olivet الفرنسية أو سانت مارتين Saint Martin، وهي تقع على بعد ه كيلو متر جنوب مدينة أورليان Orleans\Orléans، وبالمدينة دير شهير أسسه كلوفيس Bouillet, Dictionnaire universel d'histoire, p.1303. . عام • Clovis

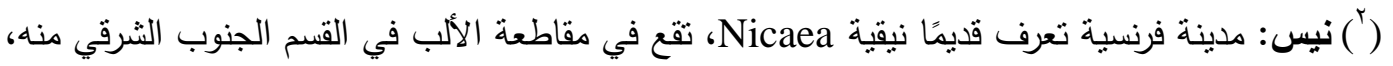

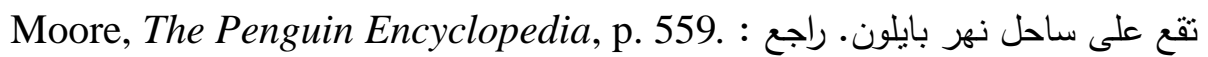

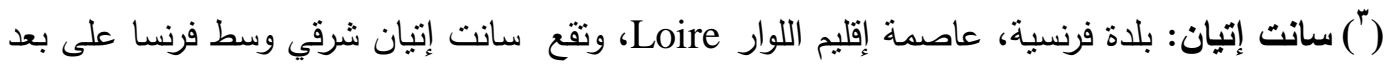

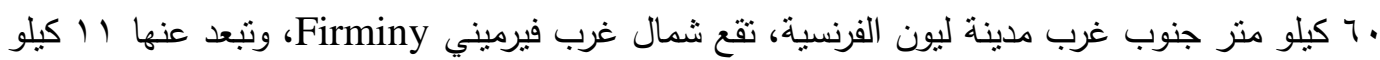
منر • راجع: . Bouillet, Dictionnaire universel d'histoire, pp.623; 635,668,1476 $\left({ }^{4}\right)$ Chaillan, Le Bienheureux, pp. 160 - 161; Prou, Les relations politiques du pape Urbain V, p. 68; Hefele, Histoire des conciles, T. 9, pp. 597-599; Rohrbacher, Histoire universelle de l'Eglise catholique, T. 20, p. 391; Christophe, Histoire de la Papauté, T. 2, pp. 373 - 374.

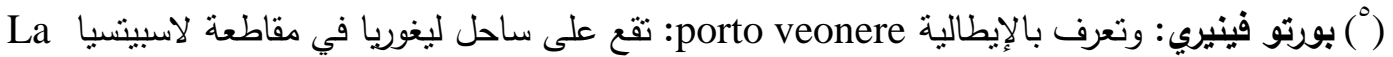
La Spezia

Bouillet, Dictionnaire universel d'histoire, p. 1746. راجع: Porto Venere ( ) كورنيتو: مدينة إيطالية تعرف قديما بـ كورنيليوم Cornelum ، وهي إحدى الولايات التابعة للدولة

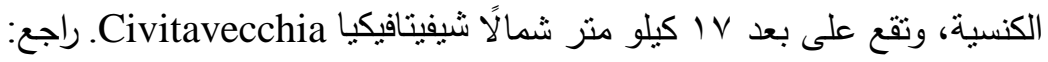
Bouillet, Dictionnaire universel d'histoire, p. 425.

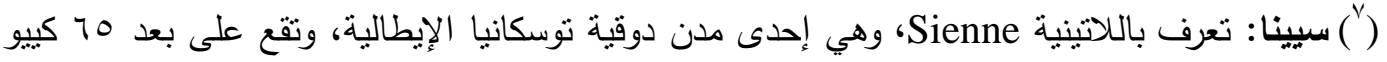

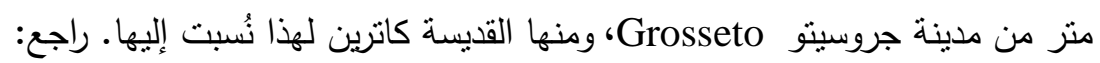
Bouillet, Dictionnaire universel d'histoire, pp. 330,752, 1662. 
التمهيديةِ لاستقبالِ الباباً فيْ رومأ(1)، ولذلكَ فرحَ الجميعُ وأخذواْ يرددونَ قولَهم: "الحمدُ ليسوعَ

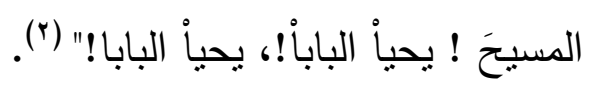

بقى الباباً بضعة أيامٍ في كورنيتو، فأعلنتِ السلطةُ الزمنيةُ خضوعَها للباباً، وفئ

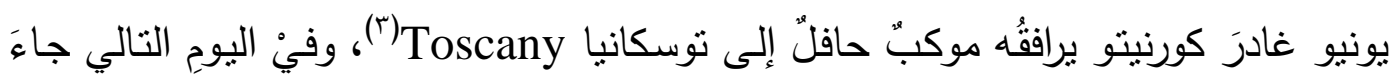

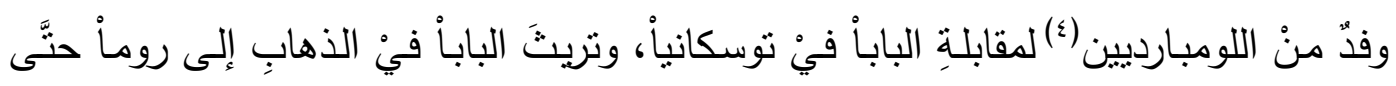
يعرفَ مشاعرَ الثعبِ الإيطالي، حيث أبدى الجميعُ حزنَه على الوضِع فيْ إيطالبا، بسببٍ

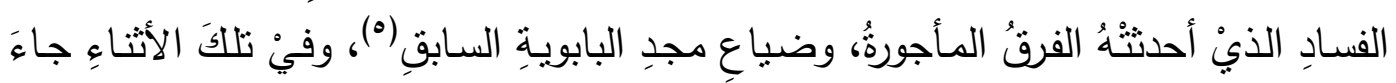
خبرُ دوتِ الكاردنيالِ "أجيديوسَ ألبورنوز" المندوبٍ البابويِّ لمدةِ \& عامًا فيْ إيطاليا، وقامَ خلالَها بحروبٍ عديدةٍ ضدَّ الفرقِ المأجورةٍ فيْ إيطاليا، وفي الوقِت نفسـهـ اندلعتْ فيْ فيتربوْ اضطراباتُ فيْ ه سبتمبرَ بسببٍ وجودِ الحشدِ الكبيرِ منْ الغرباءِ عقبَ وصولِ الباباُ، وراحَ

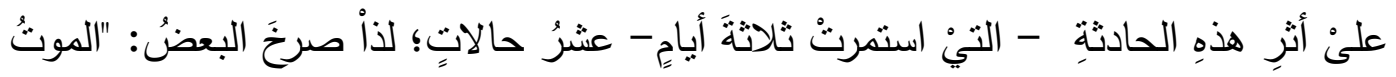

(') حيت أحضر تريناكري Trinacrie المهندس غاوتتيلين دي براديل Gaucelen de Bradhale، لإجراء ترميمات في نوفمبر Rohrbacher, Histoire universelle de l'Eglise, T. 20, p. 390; Pastor, Histoire des papes, T. 1, p. 112.

$\left(^{2}\right)$ Chaillan, Le bienheureux, pp. 161 - 165; Raynaldi, Annales Ecc.,T. 26, ann. 1366, n. 26, p. 136; Christophe, Histoire de la Papauté, T. 2, pp. 367-368; Muratori, Annali d'Italia, T. 8, p. 266.

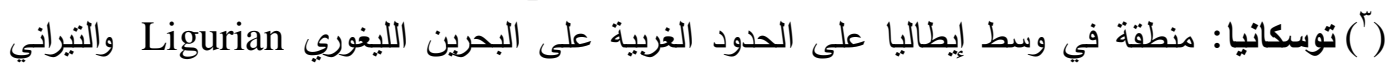

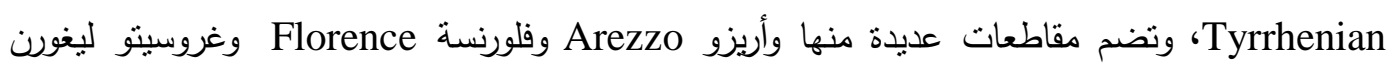

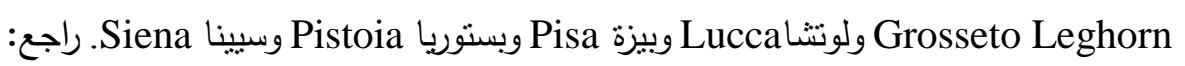
Moore, The Penguin Encyclopedia, p. 802; Bouillet, Dictionnaire universel d'histoire, pp. 586, 1156.

( ) اللومبارديون: هم سكان إقليم لمبارديا الواقع في شمال إيطاليا، تحده سويسرا Switzerland من

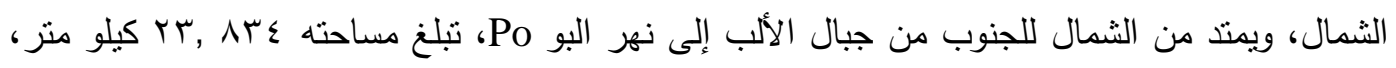

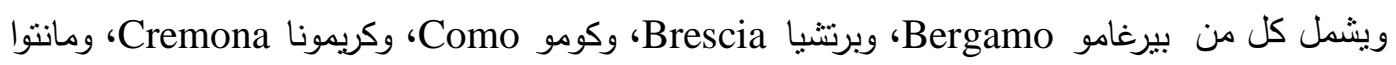

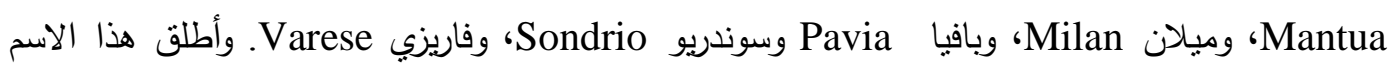
على كل الجزء الإيطالي التي سيطر عليه اللومبارديون، الذي يضم شمال ووسط وجنوب إيطاليا. للمزيد: Bouillet, Dictionnaire universel d'histoire, p. 110; Moore, The Penguin Encyclopedia, pp. 464-465.

$\left(^{5}\right)$ Baluzius, Vitae paparum avenionensium, Tome 1, pp. 362-363; Albanès, Vies antiques du pape Urbbain V, pp. 17-18; Muratori, Annali d'Italia, Tome 8, p. 266; Christophe, Histoire de la Papauté, Tome 2, pp. 376-377. 


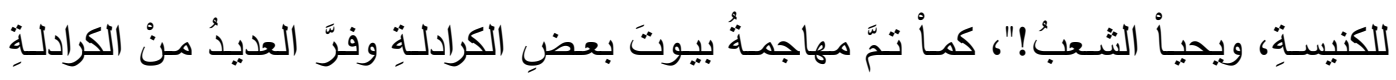

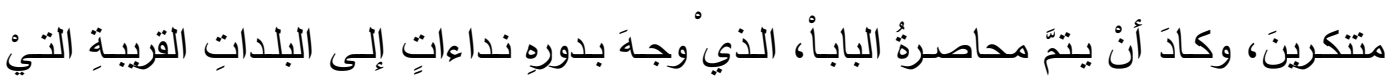

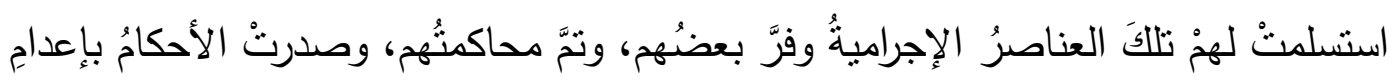

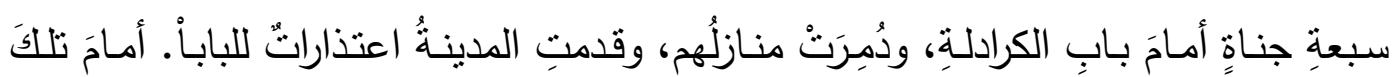

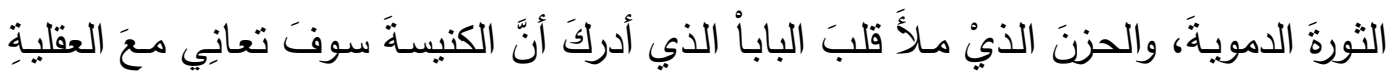
الإيطاليةِ(1).

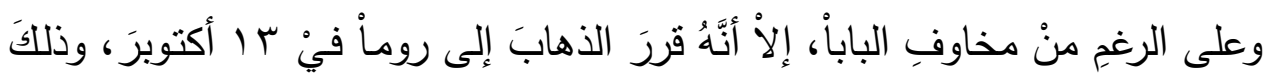

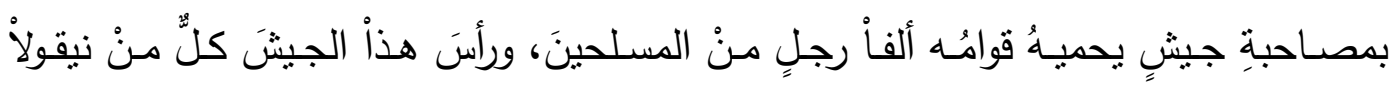
ديسني Nicolas d' Este مركيز فيرارا Marquis de Ferrare (r) وانضخَ إليه أماديوسُ

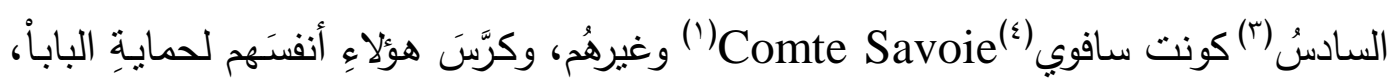

(') Chaillan, Le Bienheureux, pp. 163-165; Simeon, chronique des quatre premiers valois (1327-1393), pp.182-183; Vies antiques du pape Urbain V, pp. 18-20; Mollat, la Fiscalité pontificale, pp.113-114;

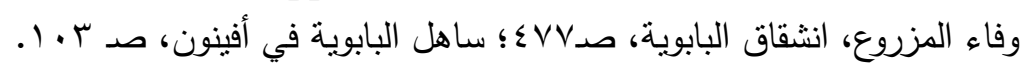

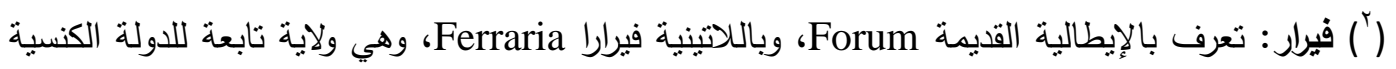

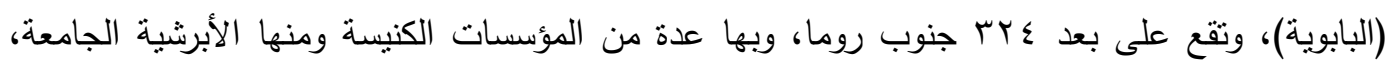

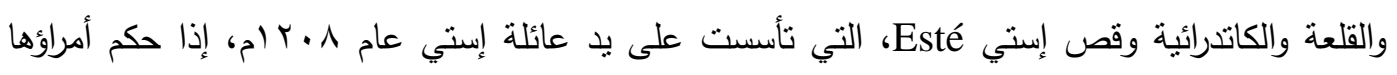

مدينة فيرارا، وأعلنوا تابعتها للبابوية: . Bouillet, Dictionnaire universel d'histoire, p. 614

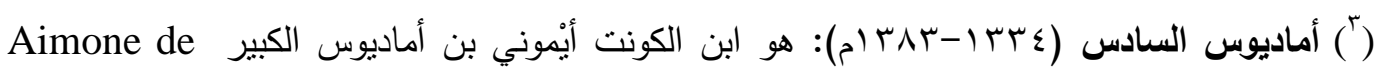

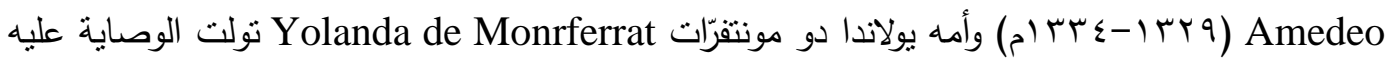

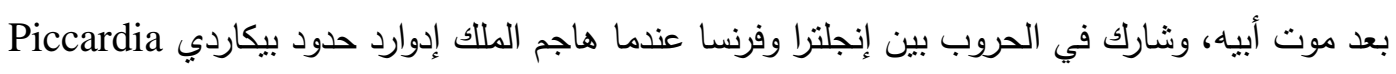

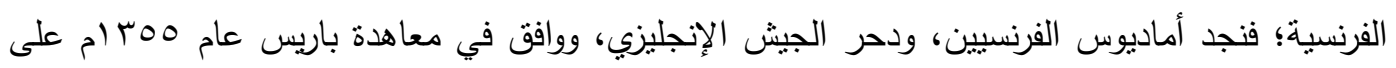

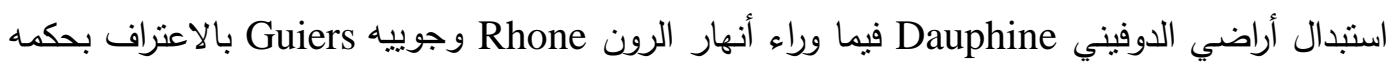
لفوسيجي Faucigy وكونتية جيكس Gex. للمزيد راجع: وراء

Cibrario, L., Storia della monarchia di Savoia, Vol. 3, Torino 1844, pp. 50-300; Setton, K. M., "The Papacy and the Levant, 1204-1571", In: The Thirteenth and fourteenth centuries, Vol. I (A.P.S.), 1976, pp. 286 - 289; Atiya, The Crusades, pp. 381-383.

(") سافوا أو سافوي Savoy: وتعرف باسم سابوديا Sabaudia، وهي دوقية فرنسية، تقع في جنوب شرق

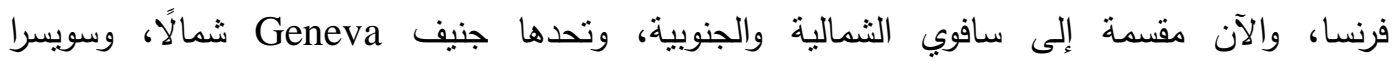
Bouillet, Dictionnaire universel من الشمال الثرقي، وإيطاليا من الشرق. راجع: Switzerland d'histoire , p. 1710; Moore, The Penguin Encyclopedia, pp. 699 -700. 
حنَّى وصلَ إلَّ روماْ فيْ 17 أكتوبرَ فيْ موكبٍ كبيرٍ وسطَ فرحةٍ منْ الإيطاليينَ بعودةِ الباباً

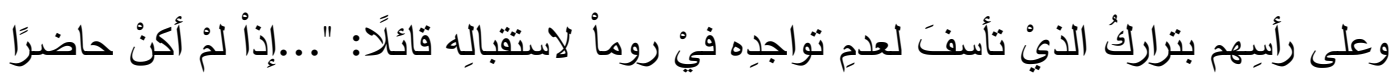

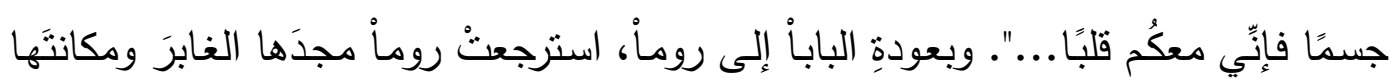

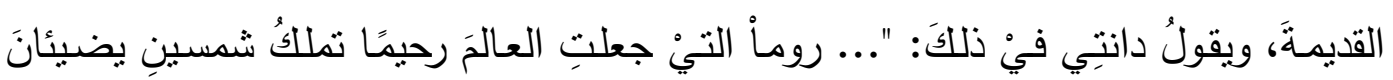

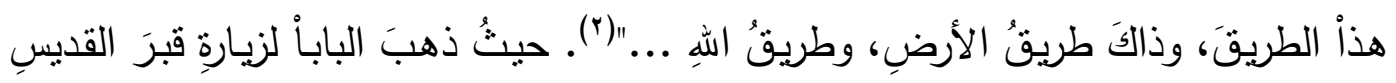

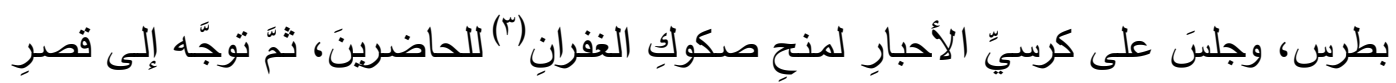

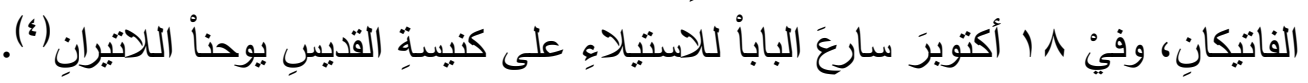

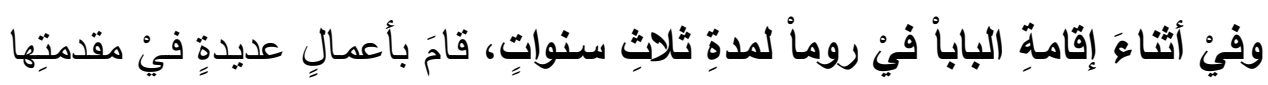

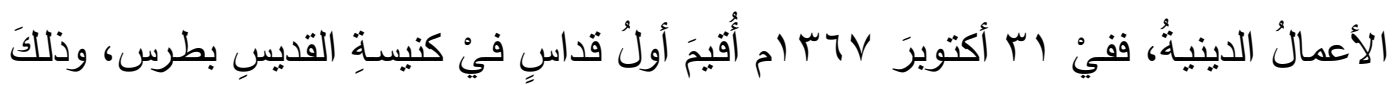
منْ أيامِ الباباً بونيفاس الثامنِ Boniface VIII (

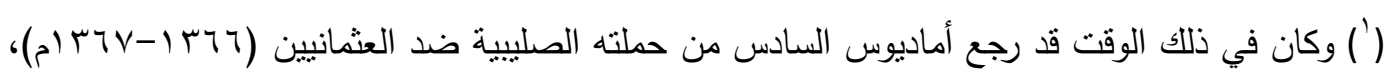

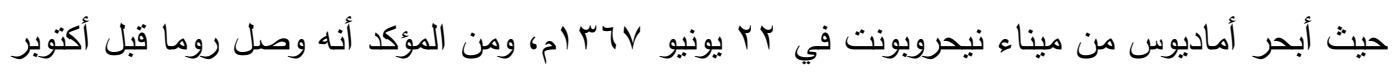

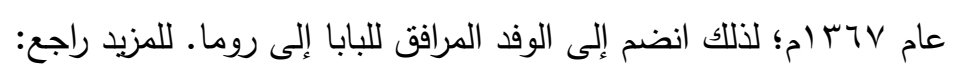
Datta, Spedizione in Oriente di AmedeoVI, pp. 150-152, Doc., Part. I, N. V, N. I, p. 183.

$\left(^{2}\right)$ Chaillan, Le Bienheureux, pp. 163-165; Baluzius, Vitae Paparum avenionensium, T. 1, pp.359 - 365; Dante A., La Divine Comédie, trad., notes et commentaires Henri Longnon, Garnier et frères, Paris, 1966, Chant. XVI; Christophe, Histoire de la Papauté, Tome 2, p. 38.

(") صكوك الغفران: هي الإعفاء الكامل أو الجزئي من العقاب على الخطايا، ويتم ضمان صكوك الغفران

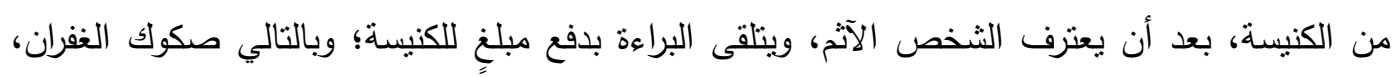

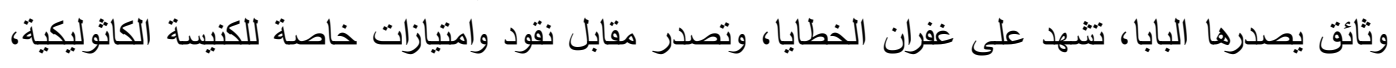

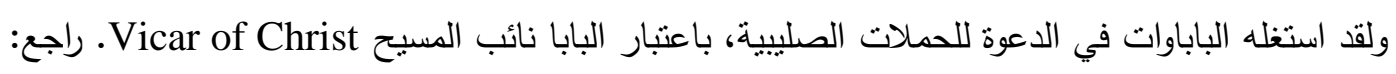

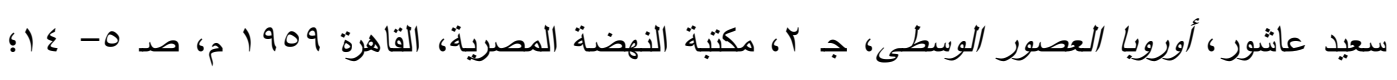

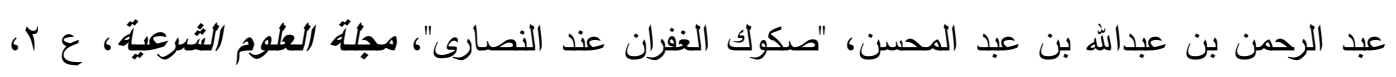

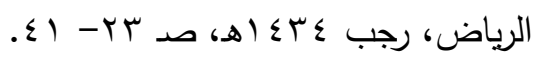

$\left({ }^{4}\right)$ Baluzius, Vitae paparum, T. 1, pp. 359 - 365; Albanès, Vies antiques du pape Urbbain V, pp. 18-20; Chesne, Histoire de Cardinaux, T. 2, p. 583; Hefele, Histoire des conciles, T. 9, pp. 599-600; Castella (C.), Histoire des papes, T. I, de Saint Pièrre jusqu'à la Renaissance, Zurich, 1943; p. 270; Christophe, Histoire de la Papauté, Tome 2, pp. 379-380.

(º ) بونيفاس الثامن: هو بندينو كيتاني Benendetto Caetani، ابن أخت البابا ألكسندر الرابع Alexander IV سيموني دي بريا Simon de Brie للوعظ ضد الجبليين لصالح صليبية شارل دي آنجو الأول، ثم صار فارن 
السيدِ وليخَ أجريفليو Guihherum de Agrifiolio أسقفًا لسافيناً Savina(')، كماً استقبلَ الباباُ القديسةَ بريجيت دِي سويدا Sainte Brigitte de Suede

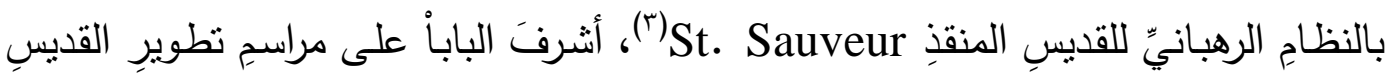

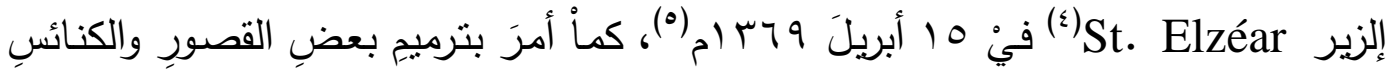

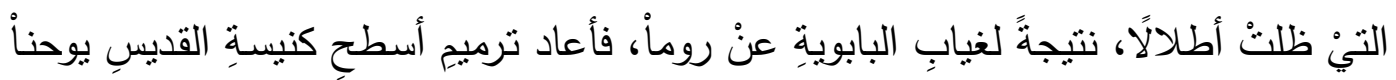

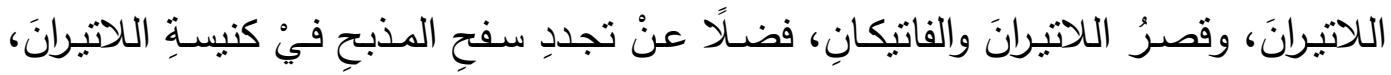

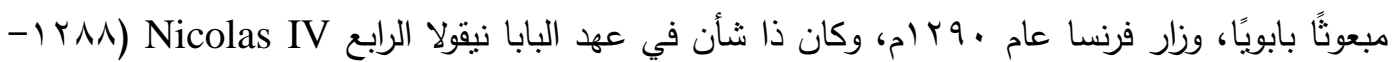

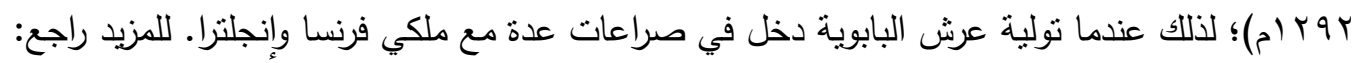
Boase, T. S. R., Boniface III, London, 1933, pp. 1-10; Cambridge Medieval History, Vol. VII, London 1928, p. 311; Kelly, J. N. O., The Oxford Dictionary, pp. 208 -210; Kuhner, H., Encylopedia of the Papacy, pp. 99-102.

(') سافينا: وتعرف باسم سان لاتزارو دي سافينا San Lazzaro di Savena، وهي بلدة في مقاطعة

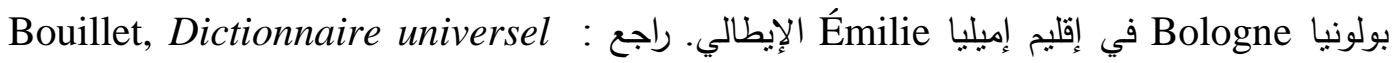
d'histoire, pp. 1566, 1843, 1845,

(†) القديسة بريجيت دي سويدا: وهي ابنه الأمير السويدي بيرجر Birger، وعندما بلغت ع ا عام تزوجت من أمير نيرسي Néricie أولف جومارسون Ulf Gudmarson عام 1 اب ام، وأنجبت ثمانية أولاد، وبعد

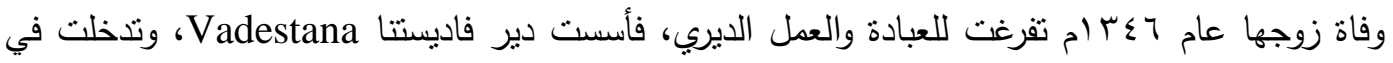

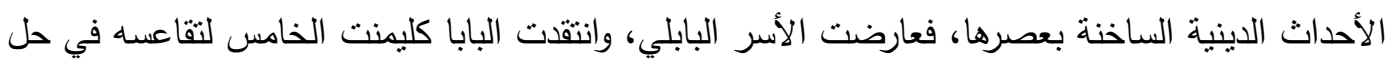

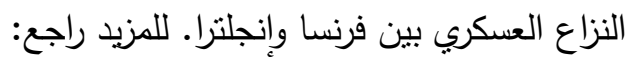

Revelationes S. Brigittae, in fol., édit. Anvers, Tome IV, c. CXXXVIII; Christophe, Histoire de la papauté, Tome 2, pp. 391-393; Homo, Rome Medieval, p. 218 ; Encyclopaedia universalis,. pp. 435 - 436.

(") النظام الرهباني للقديس المنقة: هو النظام الذي أسسته القديسة بريجيت دي سويدا عام ع ؟بام للرهبات عندما سلكت العمل الديري، ويرجع اسم المنقذ نسبة للسيد المسيح عيسى، كما عرف هذا النظام:

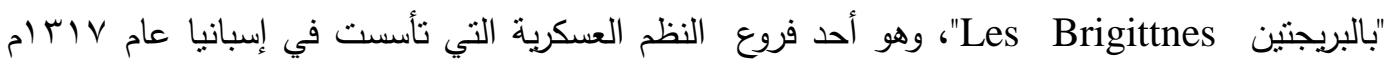
بعد حل نظام هيئة المعبد أو الداوية، وتم منح ممنلكاتها لهم. راجع: Bouillet, Dictionnaire universel d'histoire, pp. 1572, 1606.

(") إلزير من صبران Blzéar of Sabran: هو بارون أنسوي Baron de Ansouis وكونت أريانو

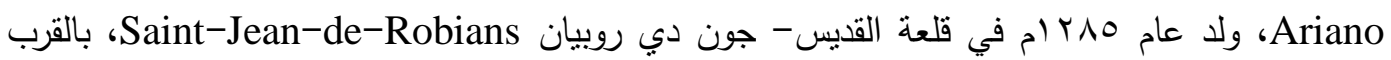

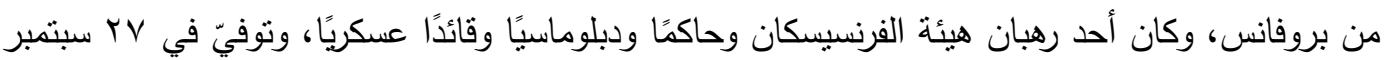

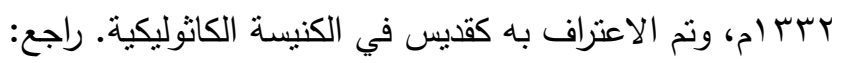

Herbermann, Charles, ed. Catholic Encyclopedia. "St. Elzéar of Sabran", New York, 1913; Bouillet, Dictionnaire universel d'histoire, p. 1552.

$\left({ }^{5}\right)$ Chaillan, Le Bienheureux, pp. 165 - 168. 


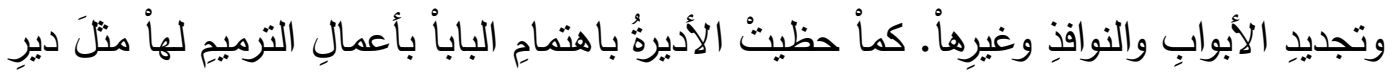

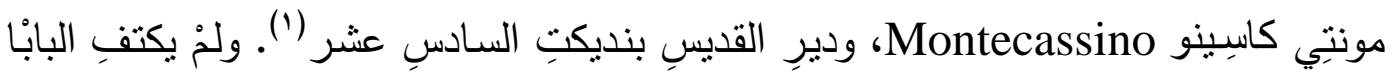

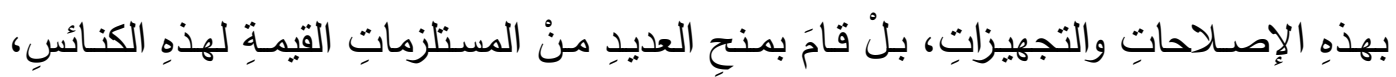

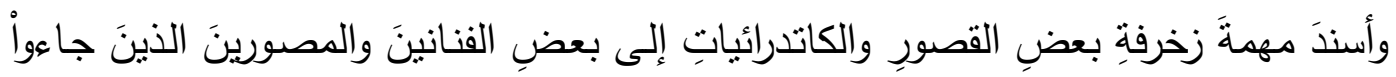

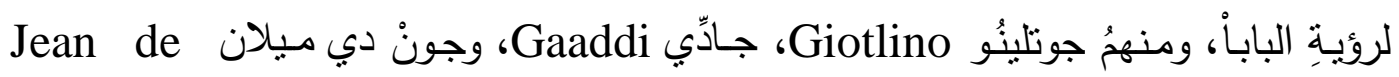

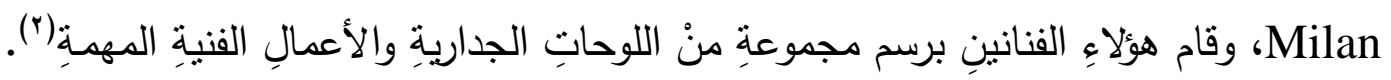

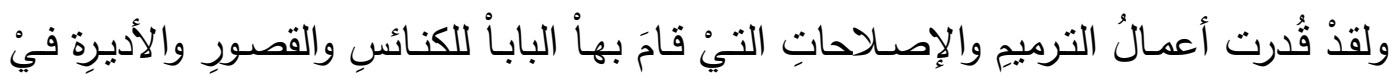

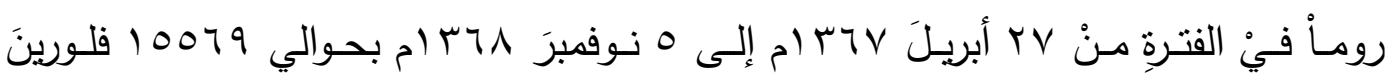

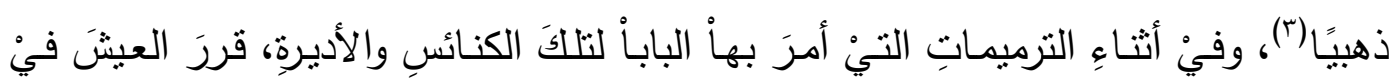

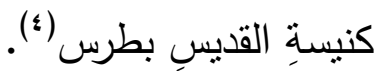

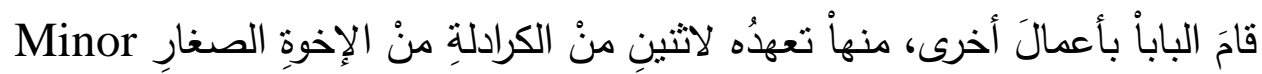
Friars

(') Christophe, Histoire de la Papauté, Tome 2, pp. 380 - 381;

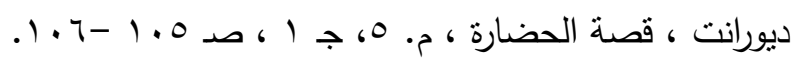

$\left.{ }^{2}\right)$ Baluzius, Vitae paparum avenionensium, Tome 1, pp. 359-365; Albanès, Vies antiques du pape Urbbain V, pp. 20, 41, 55, 72, 102; Chaillan, Le Bienheureux, pp. 168-171; Osborne, Lost Roman Images of Pope, p. 21.

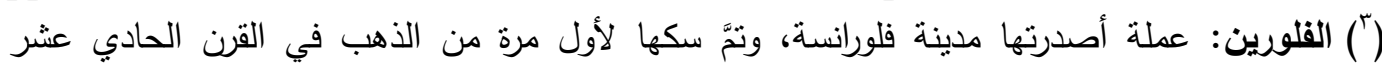

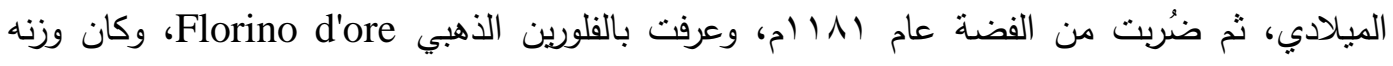

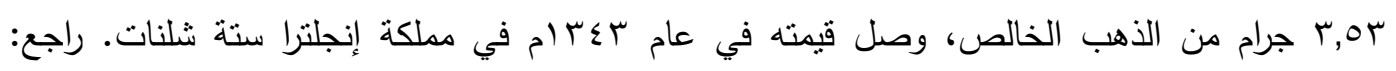

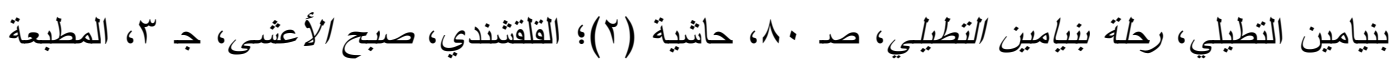

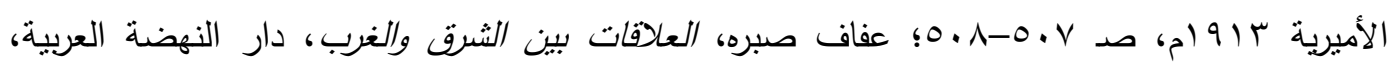

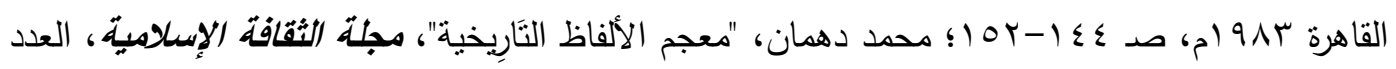

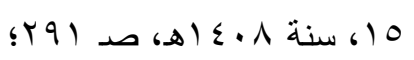

Hanson, J. L., A dictionary of Economics and Commerce, London, 1975, p. 210. ( $\left.{ }^{4}\right)$ Kirsch, Die Ruckkehr der Papste Urban V., pp. XV - XVI.

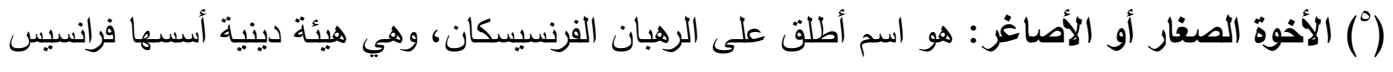

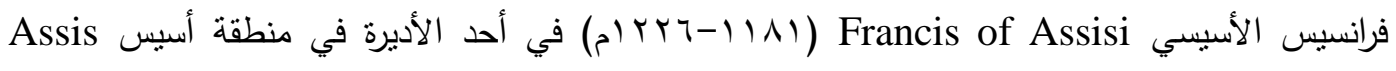

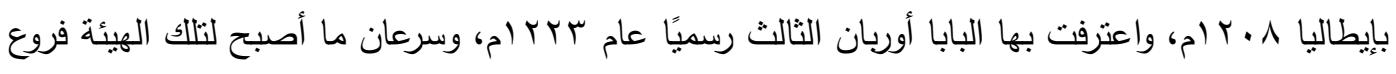

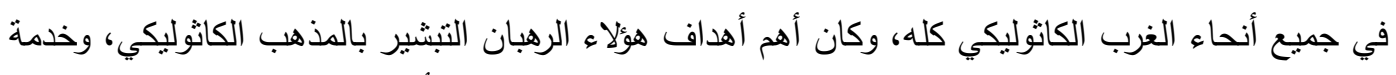

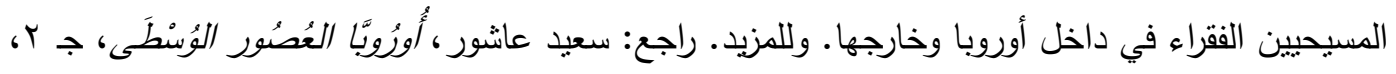




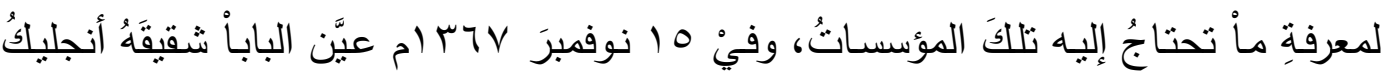

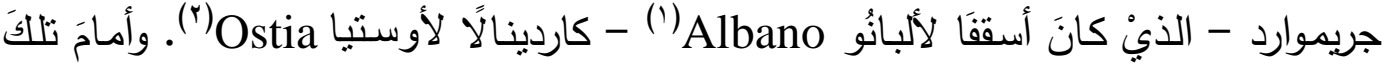

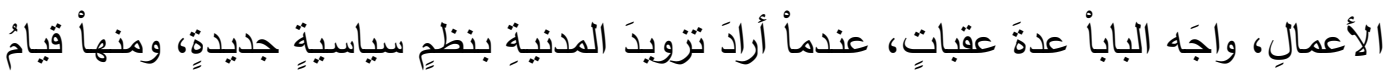

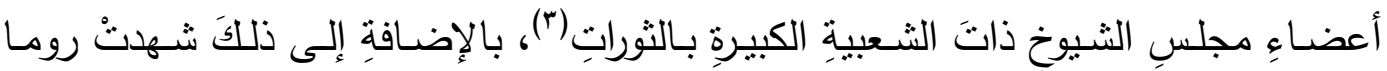

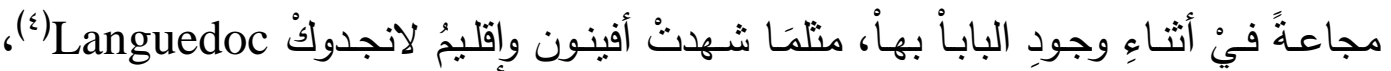
لذلكّ أرسلَ الباباً إلى المقاطعاتِ الأخرى لإرسالِ حمولاتِ القهح إلى رومأ، وأمرَهم بتقديح ماْ

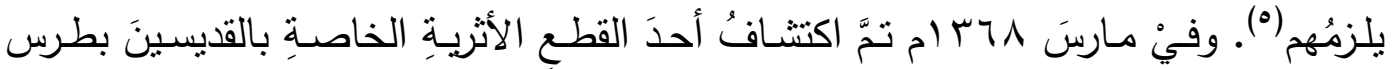
وبولسَ مخبأةً فيْ كنيسةِ اللآتيرانِ، بالإضـافةِ إلى بعضِ الأوعيةِ الفضيةِ التيْ تحتوِي على رؤوسِ الرسلِ المباركةِ بطرس وبولسَ؛ وكانَ لهذا الاكتشافِ أثرّز كبيرٌ على تواجدِ الكثيرِ منْ

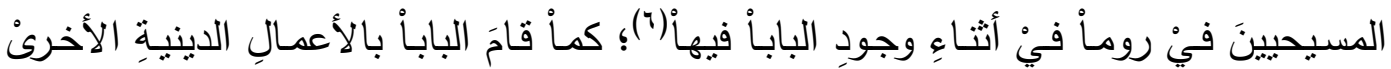

صد اء - بـ؛ عادل هلد، العلاقات بين الدغول وأوروبا وأثرها على العالم الإسلامي، دار عين للاراسات، الطبعة الأولى، القاهرة \99 (م، صد 199؛

Moorman, J. R., History of the Franciscan order from its origins until the year 1517, London, 1968.

(') ألبانو: هي أحدي المدن الإيطالية التابعة للدولة الكنيسة (البابوية)، وتقع على بعد · r كيلو منز جنوب

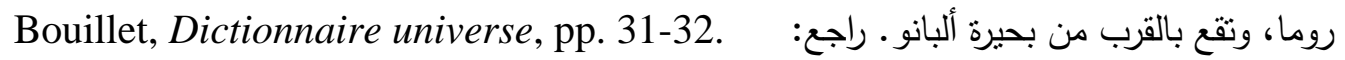
$\left({ }^{2}\right)$ Baluzius, Vitae paparum avenionensium, T. 1, p. 365; Albanès, Vies antiques du pape Urbbain V, pp. 20-21; Christophe, Histoire de la Papauté, T. 2, p. 383.

$\left({ }^{3}\right)$ Francesco Antonio Vitale, Storia diplomatica de' senatori di Roma dalla decadenza dell'imperio Romano, Tome I, Roma 1791, p. 302.

( ) لانجدوك الفرنسية: أو أوكستانيا Occitania مدينة فوري Forez وليون Lyon وأوفيرن Auvergne وماسيف Massif، ومن الجنوب روسيليون Roussillion وكونتية فوا Foix، ومن الجنوب الثرقي البحر المتوسط، وفي الثرق نهر الرون، أما في ومني الغرب رويرن Rouergne، ومن أهم مدنها الرئيسية نولوز Toulouse (العاصمة التاريخية)، ومونبلييه

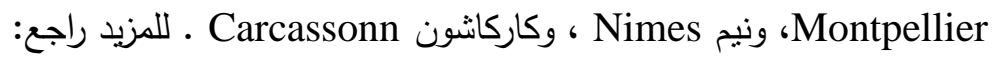
Moore, The Penguin Encyclopedia, p. 441; Bouillet, Dictionnaire universel, p. 1040 ;

$\left(^{5}\right)$ Chaillan, Le Bienheureux, pp. 172 - 175.

(6) Albanès, Vies antiques du pape Urbbain V, pp. 21,55,. 72, 76 -79, 102; Baluzius, Vitae paparum avenionensium, T. 1, p. 365; L'abbé Rose, Etudes historiques et religieuses sur le XIV siècle, Avignon, 1842, p. 379; Osborne, Lost Roman Images of Pope, p. 21. 
فيهاًْا(')، وأثتاءَ تواجدِه هنالكَ جاءَ إلبه الثاعرُ الكبيرُ بتراركُ، الذيْ كتبَ إليه مرارًا بالعودةِ إلىى

رومأ)

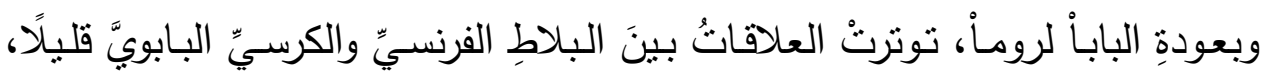

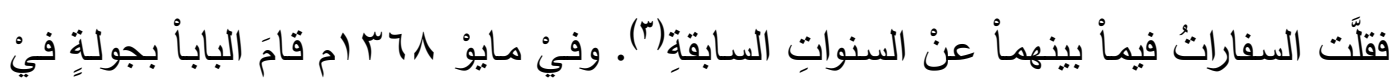

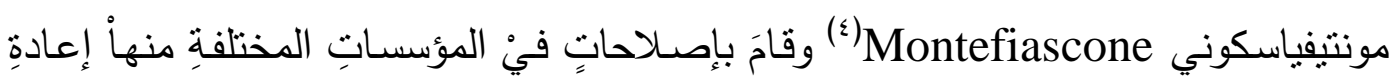

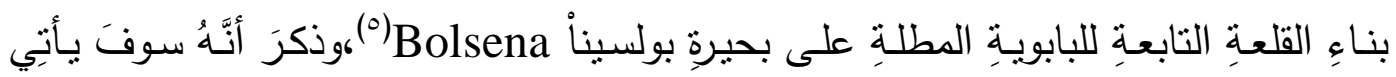

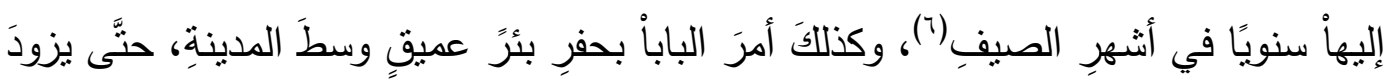

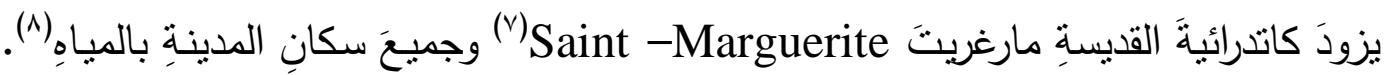

(') للمزيد عن الأعمال الدينية التي قام بها أوربان الخامس في روما ومنها صيانة المقدات الدينية

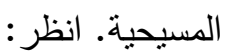

Chesne, Histoire de Cardinaux François, T. 2, pp. 583-584; Chaillan, Le Bienheureux, pp. 171-175; Baluzius, Vitae paparum avenionensium, T. 1, p. 403.

Chaillan, Le Bienheureux, pp. 176 -187.

( ) عن بترارك وموقفه من عودة البابا إلى روما ـ راجع:

$\left.{ }^{3}\right)$ Prou, M., les relations politiques du pape Urbain V., pp. 68 - 98.

(") مونتفياسكوني: هي بلدة إيطإلية في مقاطعة فيتيربو Viterbo في لاتسيو Latseo في وسط إيطاليا،

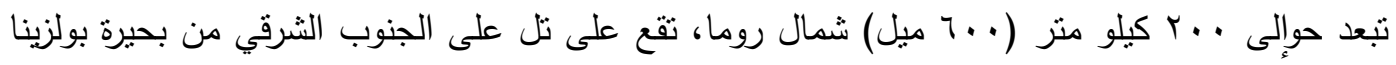

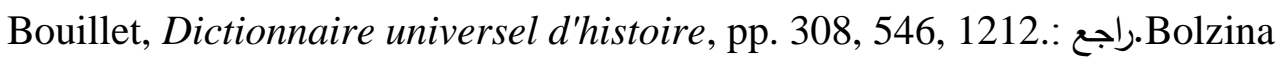

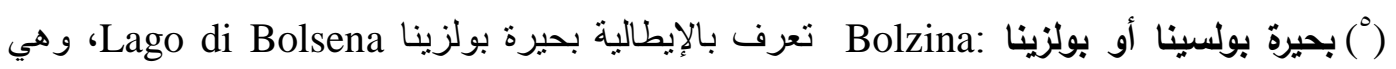

Bouillet, Dictionnaire universel, pp. 546, 1212.

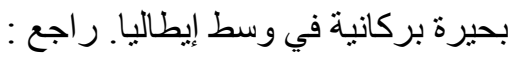

$\left(^{6}\right)$ Kirsch, J. P., Die Ruckkehr der Papste Urban V., p. XVI; N. 8, p. 56 ; N. 14, p. 58 ; N. 18 , p. 61 ; N. 25 , p. 61 ; N. 27 , p. 61 ,

( ) القديسة مارغريت: هي مارغريت من وسكس Margaret of Wessex، أو القديسة مارغريت من

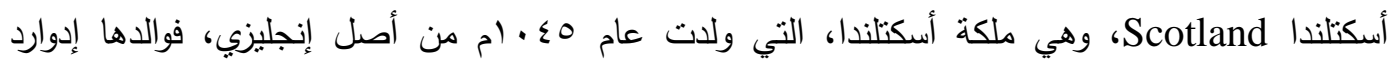

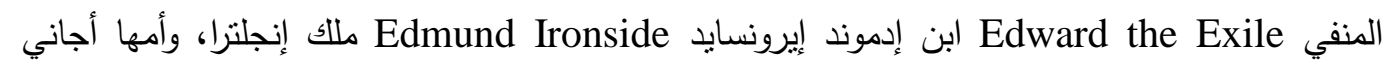
Agani من أصل بلغاري، وتزوجت مارغريت من نالكوم الثالث Nalcom III، وهي والدة لثلاثة ملوك

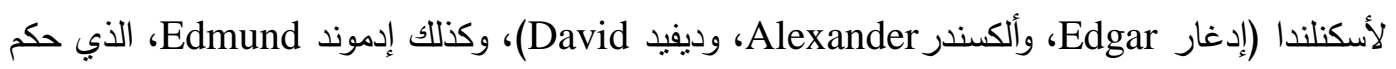

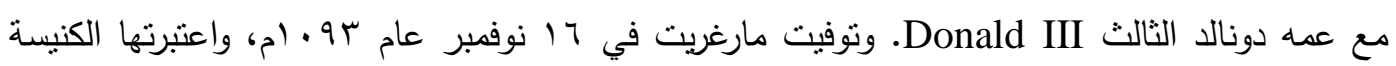

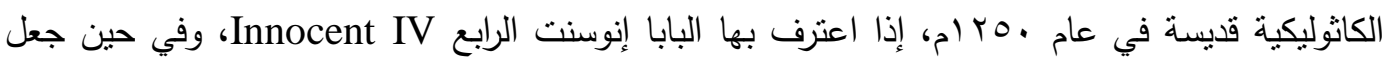

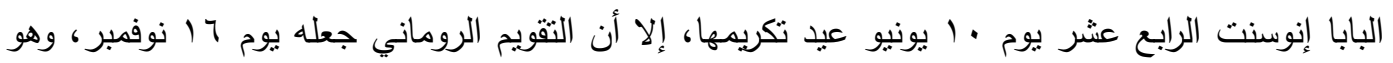

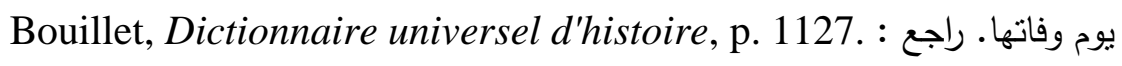




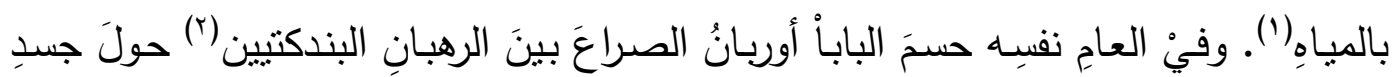
القديسِ توماً الأكويني Thomas Aquinas، الذين كانَ مقدسًا فيْ مدينةِ مونتيفياسكوني (َّان. مونتيفياسكوني (r)

وعلى أيَّةِ حالٍ شعرَ المواطنونَ الإيطاليون بالقلقِ لخوفِهم منْ رحيلِ الباباْ؛ لذا أرسلواْ

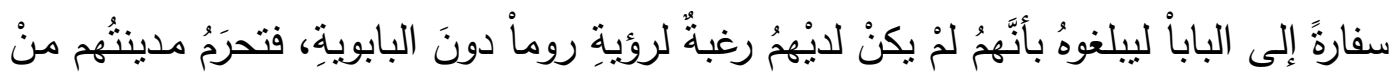

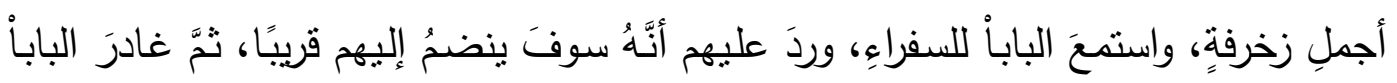
مونتيفياسكوني، واتجـهَ إلىى فيتربوْ، وهناكََ طلبَ منْ الإمبراطورِ شـارلَ الرابع تأكيدَ سلطةِ

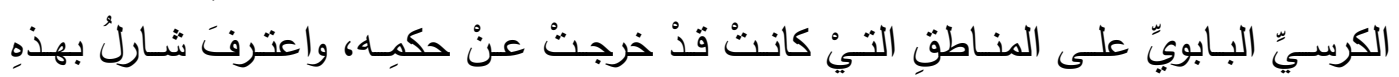

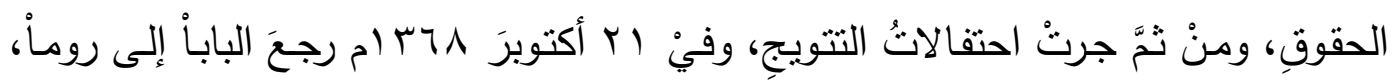
وبصفُ المؤرخونَ هذاْ المشهدَ بأنَّ الإمبراطورَ انتظرَ الباباُ خارجَ المدينةِة، وسارَ مشيًا على

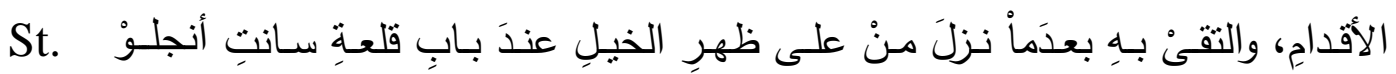
Angeles العظيِِ، وأمامَ هذا المشهد، كانَ الإيطاليونَ فيْ فرح شديدٍ لرؤيةِ الباباً والقيصرِ متحدينَ، ممَّاْ

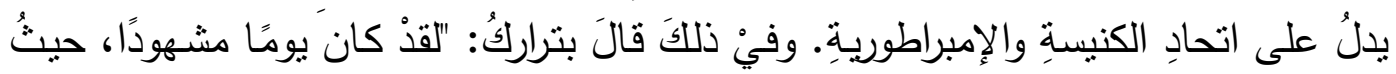

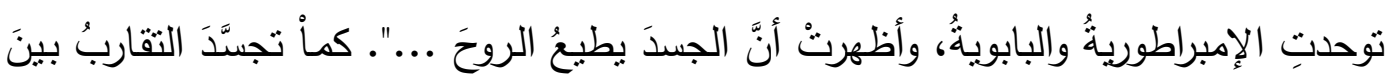

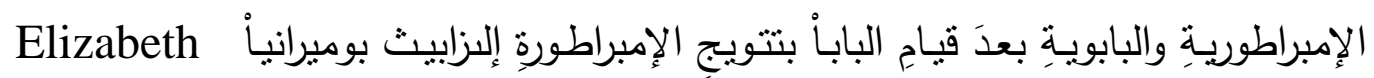
Pomerania

(') Chaillan, Le Bienheureux, pp.184 -186; Baluzius, Vitae paparum, T. 1, pp. 367- 377.

( آ الرهبان البندكتيين: هم أنباع نظام القديس بندكت، هو نظام ديني كاثوليكي يحترم دور القديس بندكت

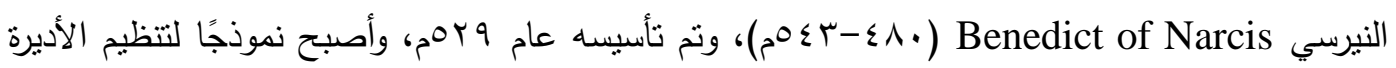

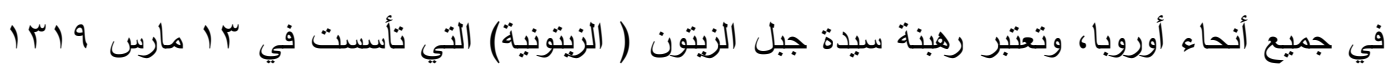

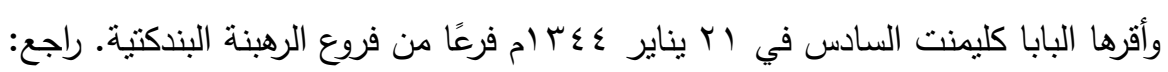
Bouillet, Dictionnaire universel d'histoire, p. 198.

$\left(^{3}\right)$ Muratori, Annali d'Italia, T. 8, p. 269; Chaillan, Le Bienheureux, p. 186; Albanès, Vies antiques du pape Urbbain V, pp. 22-24.

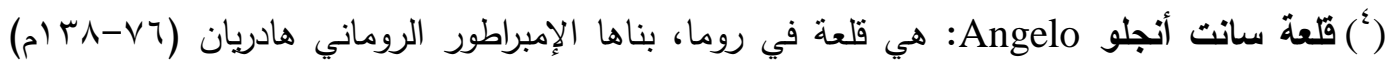

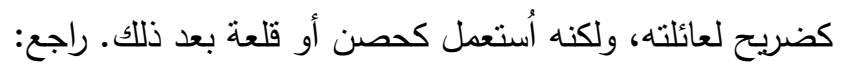
Bouillet, Dictionnaire universel d'histoire, p. 293.

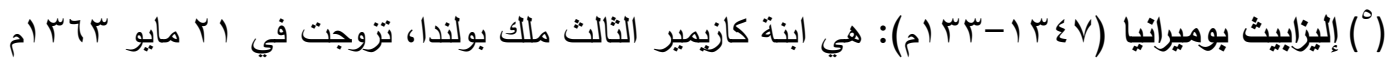

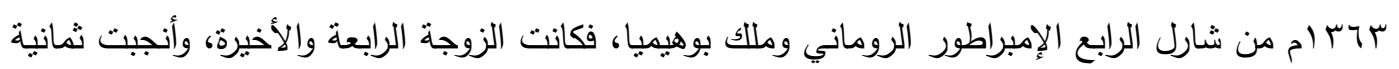


ومنْ الأعمالِ التيْ قامَ بهاْ الباباْ فيْ روماً على الجانبٍ السياسيِّ، استقبالِه لكلِّ منْ

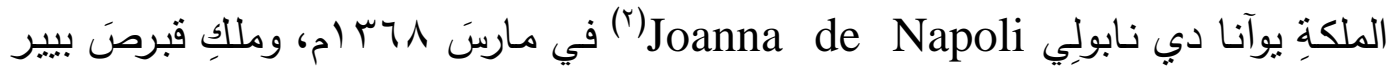

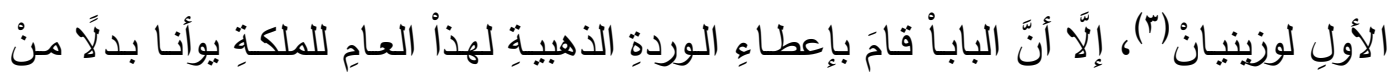

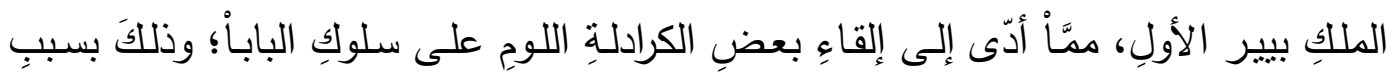

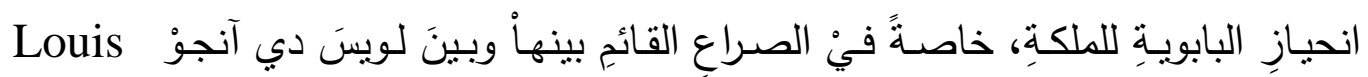

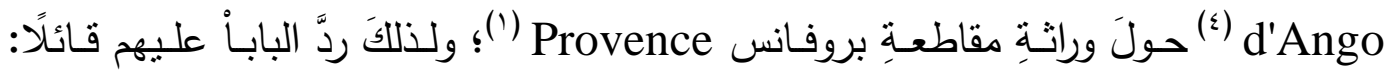

أبناء، وتم تتويجيها بعد زواجها بخمس سنوات من قبل البابا أوربان الخامس في الأول من نوفمبر دبسام ملكة لألمانيا وبو هيميا. راجع :

Lerski, G.I., Historical Dictionary of Poland, 966-1945, London, 1996, pp. 250, 316; Bouillet, Dictionnaire universel d'histoire, p. 357; Werunsky, Geschichte Kaiser Karls IV, pp.723-740, 76-810.

$\left(^{1}\right)$ Albanès, Vies antiques du pape Urbbain V, pp. 23-24; Chaillan, Le Bienheureux, pp. 186-188; Muratori, Annali d'Italia, T. 8 , pp. 270 -271.

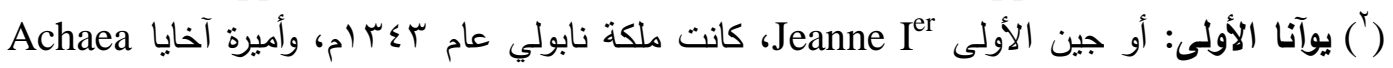

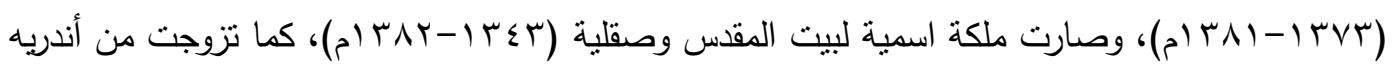
الهنغاري Andre de Hongrie ابن عمها، وبعد اغتبال هذا الزوج، خُطبت لعشيقها ومدبر اغتيال زوجها لويس دو نارنت Louis de Tarente، ولذلك قام لويس الأول ملك هنغاريا وشقيق الملك أندريه الذي تم أن

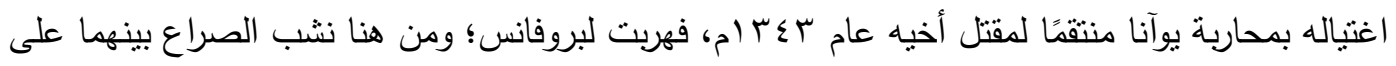

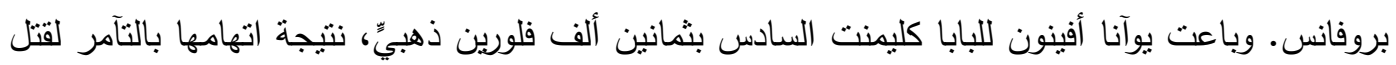

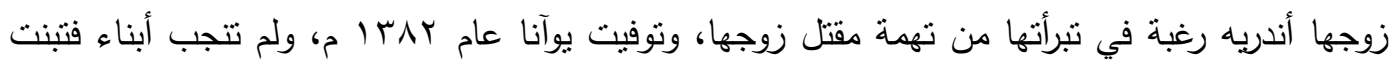

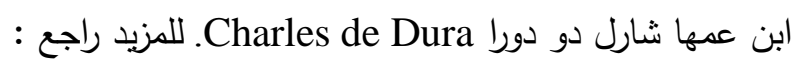
Bouillet, Dictionnaire universel d'histoire, pp. 958, 1125; Engel, P., A History of Medieval Hungary 895-1526, London 2001, pp. 105 -165.

(") وجاء الملك بيير إلى البابا في روما عام رجسام؛ ليعيد طرح فكرة توجيه حملة صليبية جديدة إلى الثرق ضد العثمانيين، خاصة بعد فثل حملته على الإسكندرية، منلما حدث في أفينون قبل ذلك حول هذاء لئل الموضوع. راجع:

Chronographia regum Francorum (1270-1380), T. 2, p. 179; Macheras, Chronique dse Chypre, pp. 120-127.

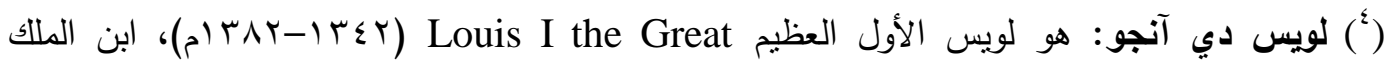

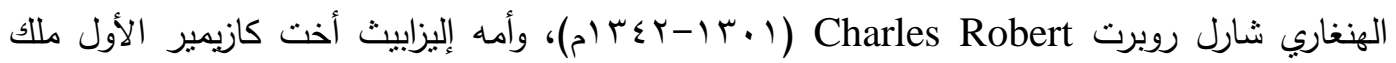

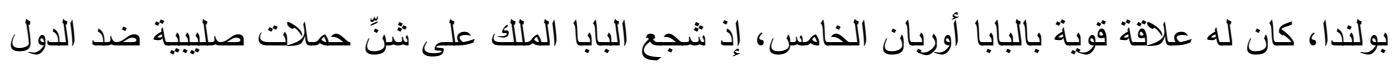

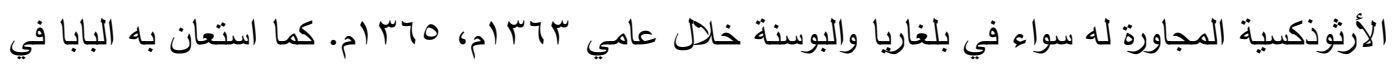

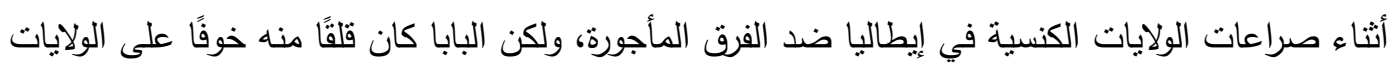

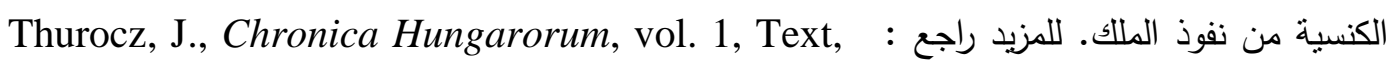




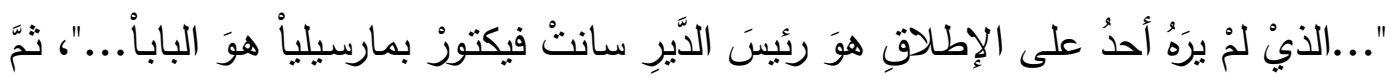

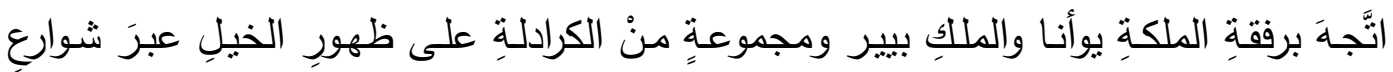

$$
\text { المدنيةِ وسطَ الحشودِ الكبيرةِ(؟). }
$$

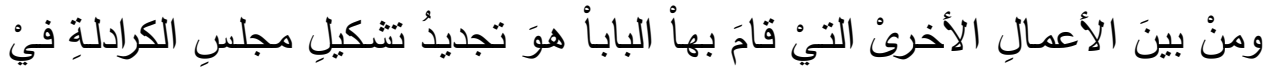

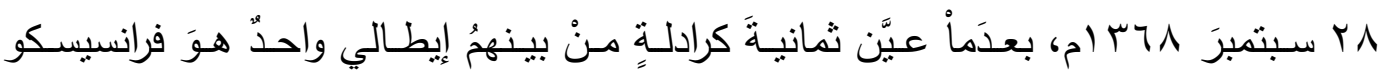

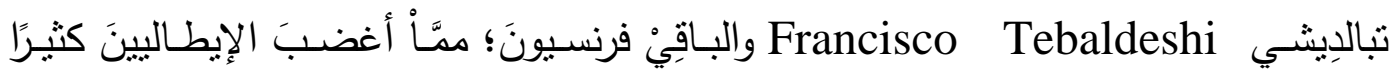

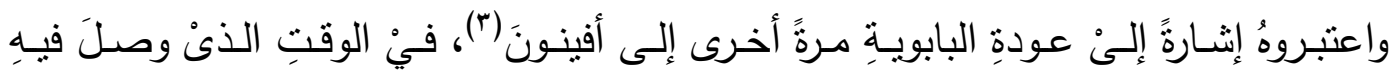

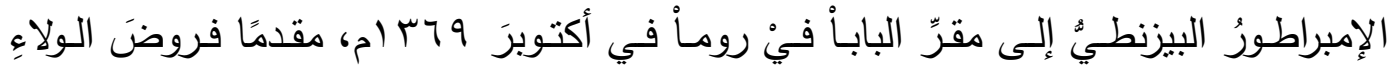

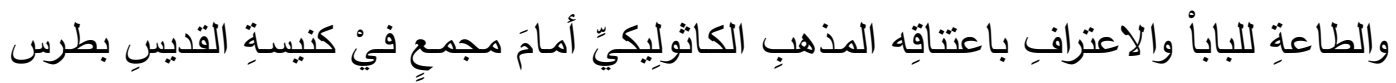

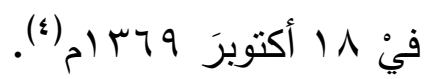

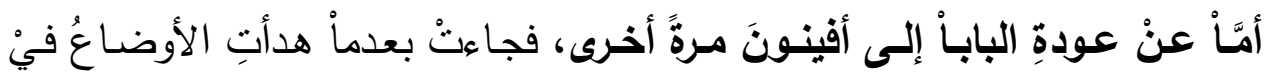

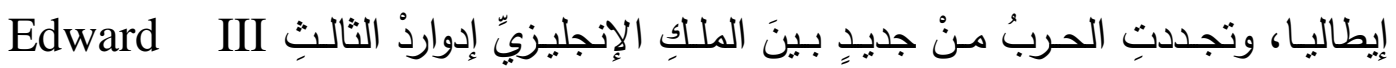

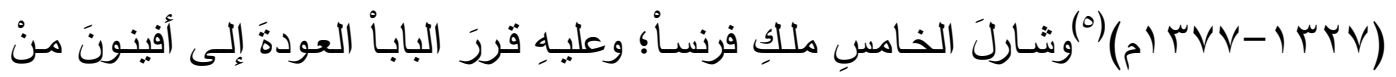

ed. E. Galántai and J. Kristó, ( B.S.M.R.), Series nova, vol 7 (Budapest, 1985), pp.180-189; Raynaldi, Annales Ecc., T. 26, ann. 1365, N. 1- 2, pp. 104-105; Christophe, Histoire de la papauté, T. 2, pp. 350 -351; Engel, A History of Medieval Hungary, pp. 105 -165.

(') مقاطعة بروفانس: مقاطعة فرنسية في جنوب شرق فرنسا تقع على الحدود مع إيطاليا، ويحدها البحر المتوسط من الجنوب ونهر الرون Rhone من الغرب. راجع: Bouillet, Dictionnaire universel d'histoire, p. 349; Moore, The Penguin Encyclopedia, p. 44.

$\left(^{2}\right)$ Chaillan, Le Bienheureux, pp. 186-188; Baluzius, Vitae paparum avenionensium, T.1, p. 389; Mollat, La Fiscalité pontificale en France, pp. 113114; Christophe, Histoire de la Papauté, T. 2, pp. 383-384.

$\left(^{3}\right)$ Chaillan, Le Bienheureux, pp. 186-188; Albanès, Vies antiques du pape Urbbain V, pp. 45, 108-110.

$\left({ }^{4}\right)$ Chaillan, Le Bienheureux, pp. 190-192; Renouard, La Papauté à Avignon, p. 56.

(1) إدوارد الثالث: هو أصغر أبناء إدوارد الثاني Fdward II Isabella de France وصاية أمه، التي كانت عاشقة للسلطة، بعدما استحوذ على السلطة عمل على جعل مملكة إنجلترا أقوى

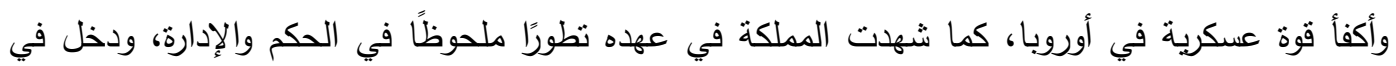
نزاع حاد مع فرنسا وملكها فيليب السادس، وانتصر الأخير عليه في موقعة كريسي Crecy عام

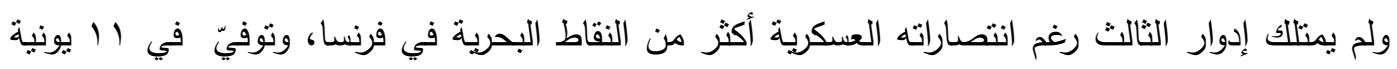




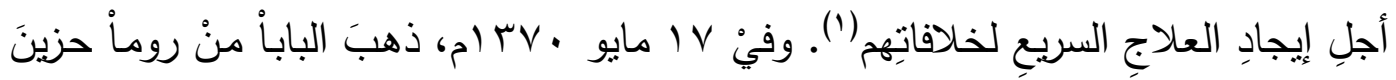

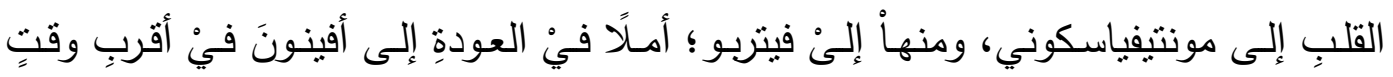

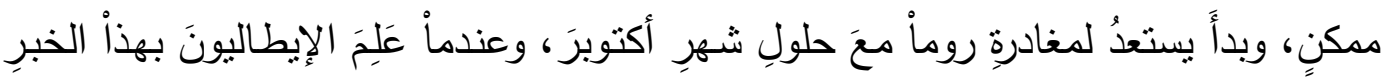

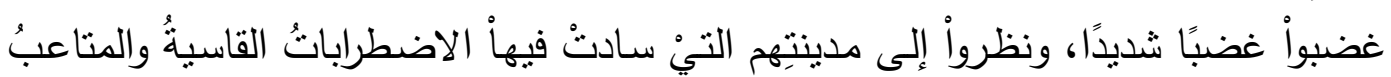

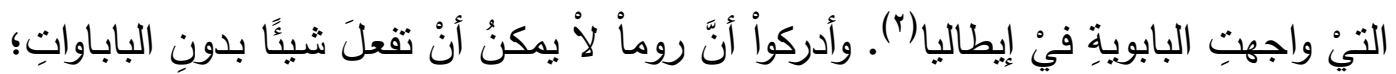

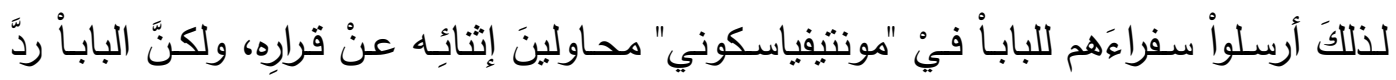

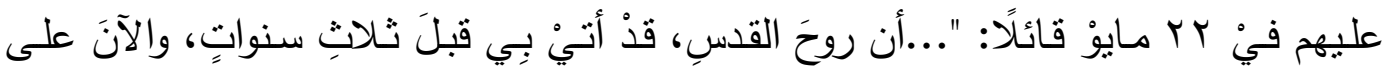

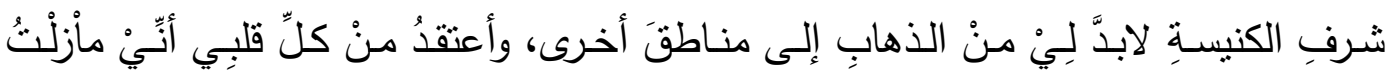

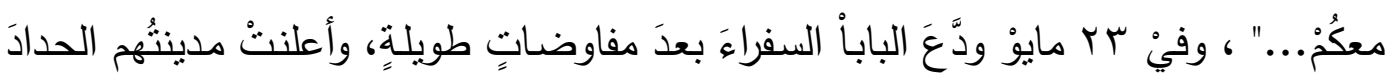

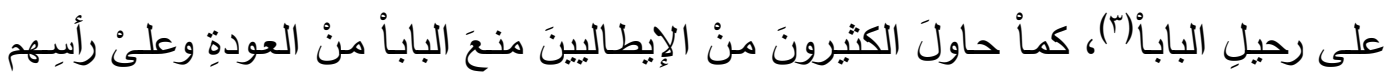

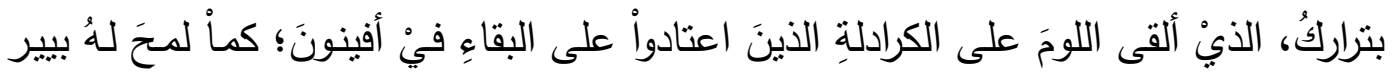
دي أراغون Pierre de Aragon - راهبُ منْ نظامِ الفرنسيسكانِ - بإمكانيةِ وجودِ شقاقِ

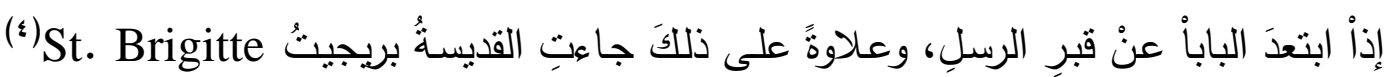

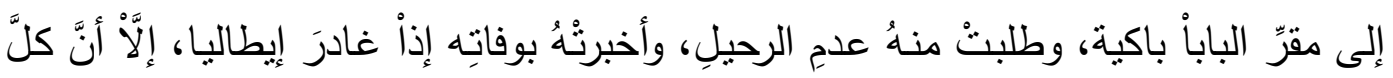

عام Shene Shr (ريشموند Richmond حاليًا)، ودفن في مقاطعة وستمنستر : Westminster

Stubbs, W., Annals of England: An Epitome of English History, London, 1876, pp. 187-188; Bouillet, Dictionnaire universel d'histoire, p. 1585.

$\left(^{1}\right)$ Baluzius, Vitae paparum avenionensium, T.1, p. 382; Vies antiques du pape Urbain V, pp. 26, 35-36; Prou, Les relations politiques du pape Urbain V., p. 79.

('آ ويرجع أسباب فنثل التجربة الأولى لإعادة البابوية إلى إيطاليا، ومنها الاضطرابات التي سادت البلاد

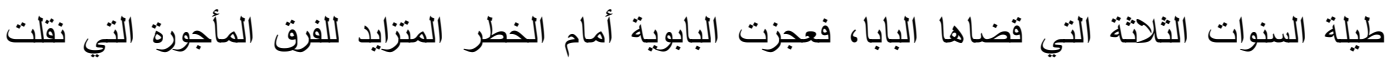

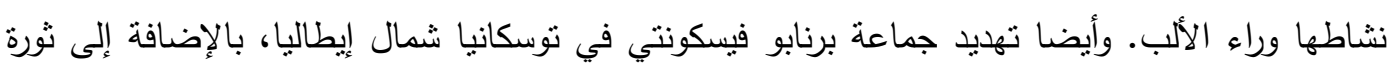

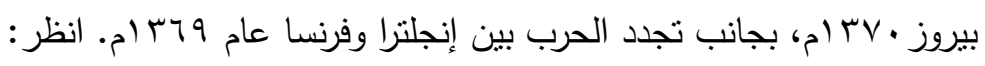
Chaillan, Le Bienheureux, pp. 192 - 197; Albanès, Vies antiques du pape Urbbain $V$, pp. 47-48, 79.

$\left({ }^{3}\right)$ Chaillan, Le Bienheureux, pp. 195-197; Albanès, Vies antiques du pape Urbbain V, pp. 48, 79.

(") كانت بيرجيت السيدة السويدية موجودة في روما أثناء وجود البابا هناك، ويذكر بعض المؤرخين بأنها مشهورة بنقوتها، وقابلت البابا في مونتقيسكوني Montemflascois، وتحدث معده بعدم عودته إلى أفينون مرة أخرى. للمزيد . Revelationes S. Brigittae, in fol., édit. Anvers, Tome IV, C CXXXVIII; Christophe, Histoire de la papauté, T. 2, pp. 391-393. 


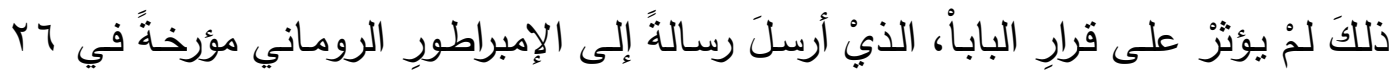

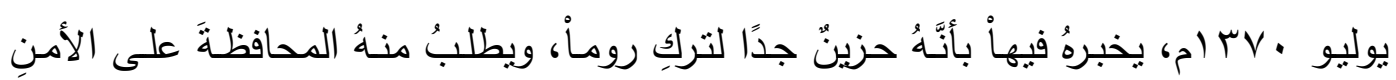
والسلاجِ فئ المقاطعاتِ الإيطاليةِ (1).

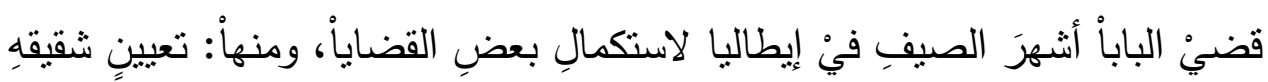

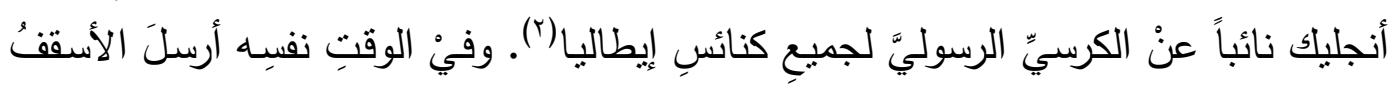

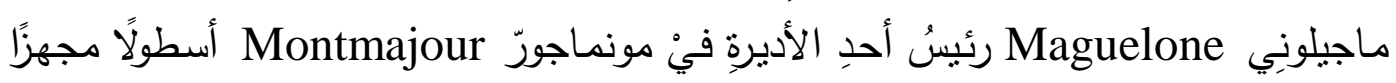

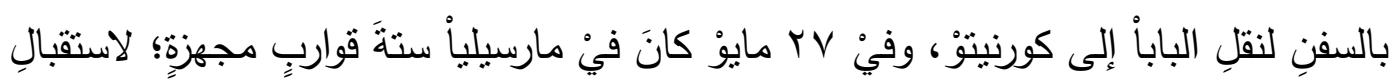

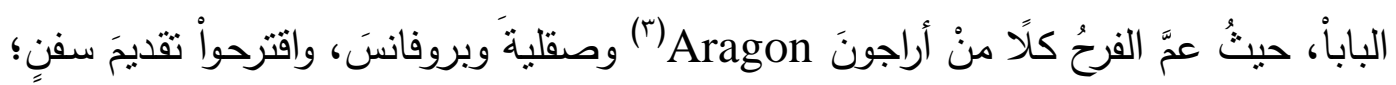

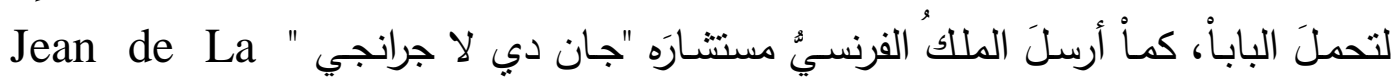
Grange

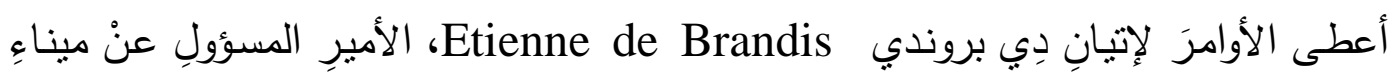

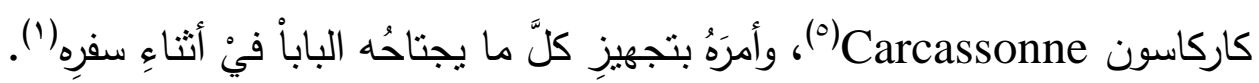

(1) Chaillan, Le Bienheureux, pp.198-100; Albanès, Vies antiques du pape

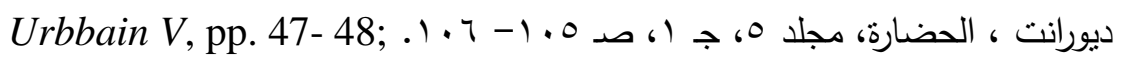

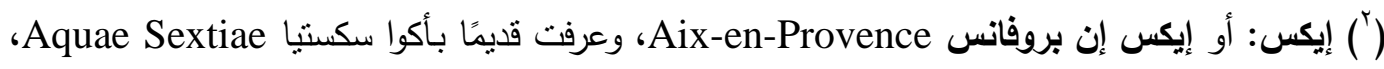

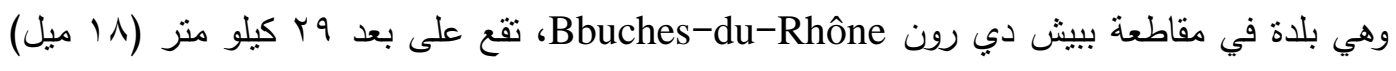
شمال وشمال شرق مارسيليا، وكانت عاصمة مقاطعة بروفانس في العصور الوسطي. راجع: Moore, The Penguin Encyclopedia, pp. 20-21.

('آ) أراجون: مدينة إسبانية نقع في الثمال الثرقي، وتضم مقاطعة ويسكا Huesca الحديثة، وتيرويل

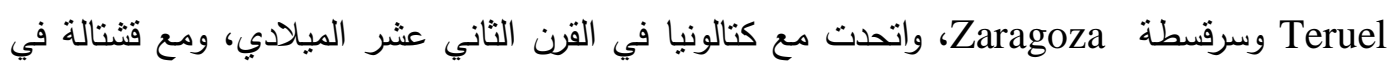

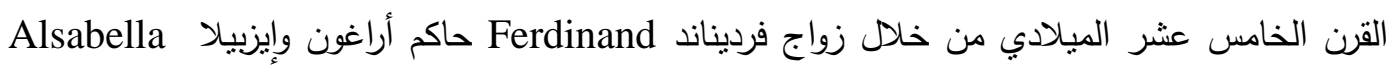

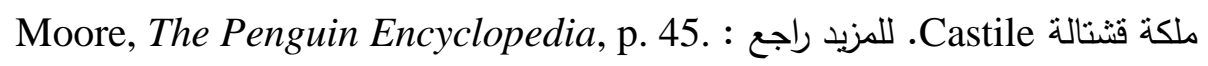

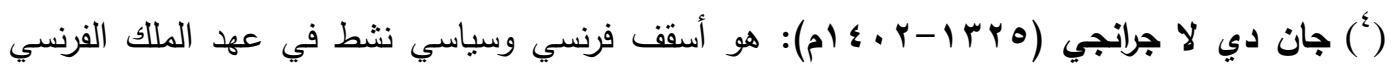

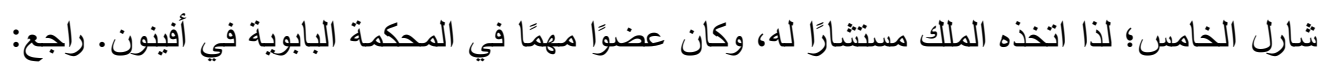
Morganstern, A. M., "The La Grange Tomb and Choir: A Monument of the Great Schism of the West", Speculum, Vol. 48, No. 1 (Jan., 1973), pp. 52-69

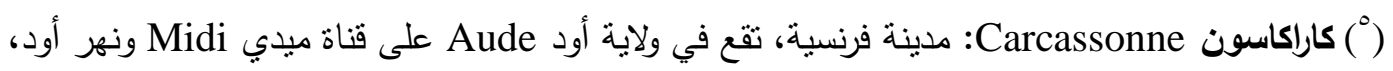

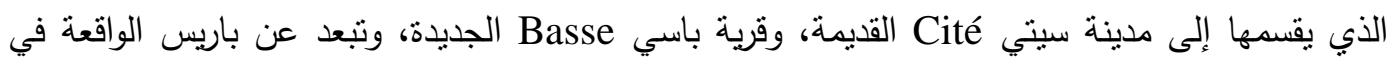

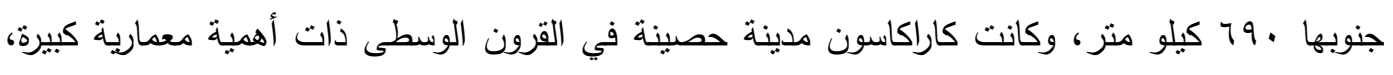

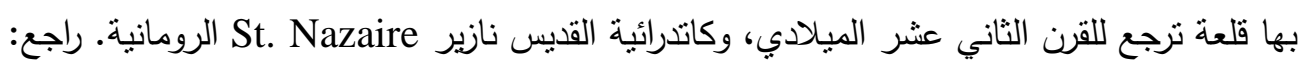




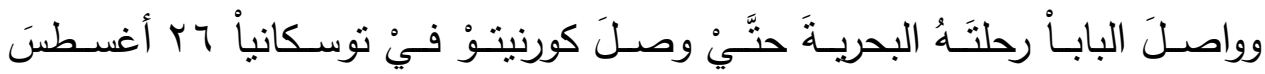
• مارسيلياُ، وبلغَ عددُ الأسطولِ المصاحبِ لهُ أربعَ وثلاثين سفينةً، وبعدَ ثمانيةِ أيامٍ دخلَ الباباً

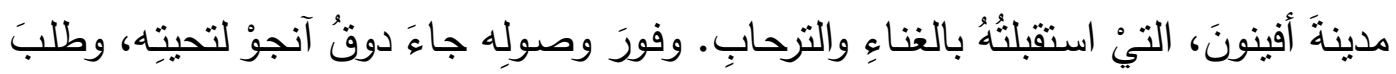

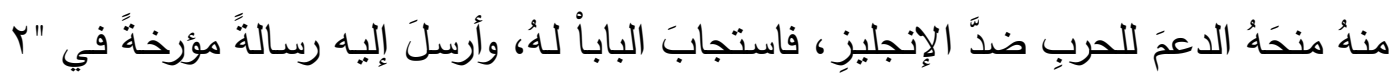

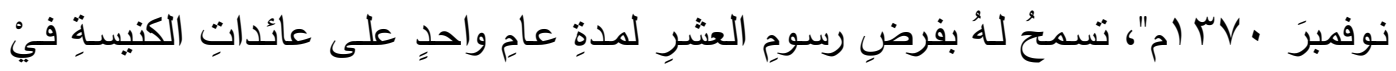

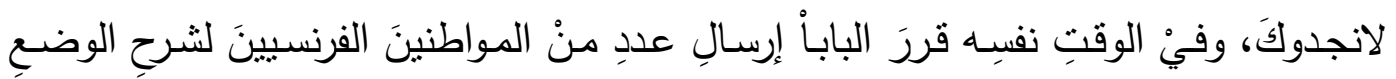

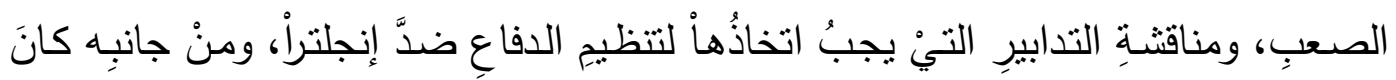

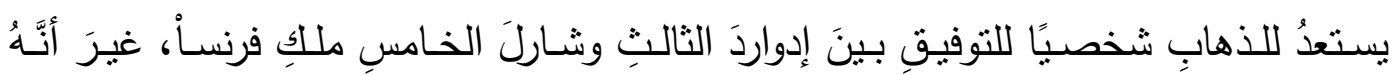

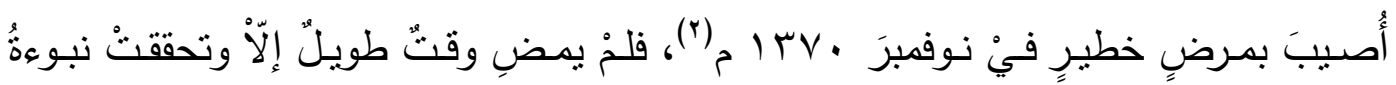

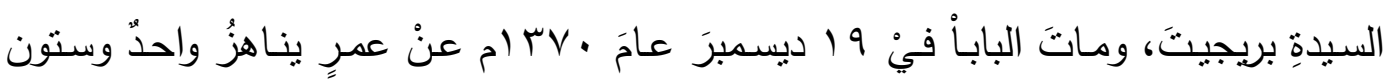

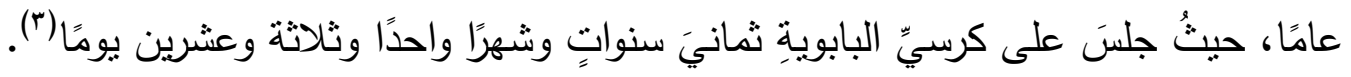

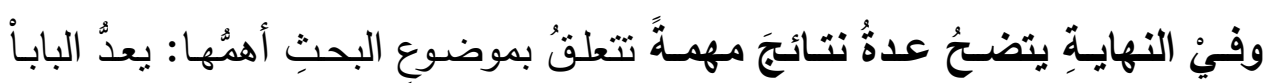

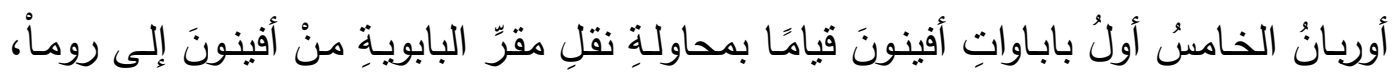

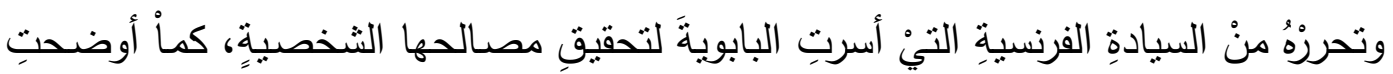

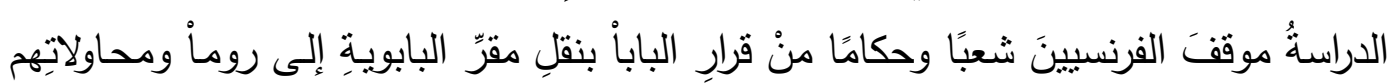
الضغطَ علىْ الباباً لعدمِ تتفيذِ قرارِه.

وبينتِ الدراسـةُ جهودَ الإيطاليينَ شعبًا وحكامًا؛ لتنفيذِ البابْا وعدَه بنقلِ مقرِّ البابويةِ

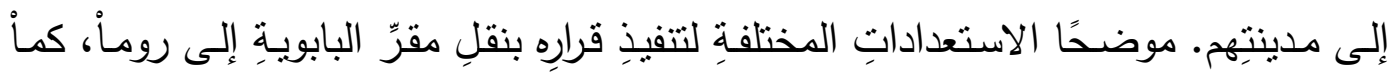

Bouillet, Dictionnaire universel d'histoire, p. 311; Moore, The Penguin Encyclopedia, p. 154.

( $\left.{ }^{1}\right)$ Baluzius, Vitae paparum, T. 1, pp. 374-375; Chaillan, Le Bienheureux, pp.100102; Chesne, Histoire de Cardinaux François, T .2, p. 584; Prou, Les relations politiques du pape Urbain V., pp. 79-80; Simeon, Chronique des quatre premiers Valois, pp. 211-213.

$\left(^{2}\right)$ Prou, Les relations politiques du pape Urbain V., p. 80; Albanès, Vies antiques du pape Urbbain V, pp. 29-30, 48, 111-112; Chaillan, Le Bienheureux, pp. 102-103; Chesne, Histoire de Cardinaux François, T. 2, p. 584.

$\left(^{3}\right)$ Chaillan, Le Bienheureux, p. 203; Moreri, Le dictionnaire, article Urbain V, Vol. 10, p. 716; Christophe, Histoire de la Papauté, Tome 2, pp. 391-395; Baluzius, Vitae paparum avenionensium, T.1, p. 382; Albanès, Vies antiques du pape Urbbain $V$, pp. 36, 49, 55 ,73, 76 - 77, $84,88,112$. 


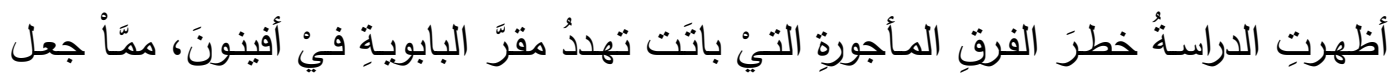

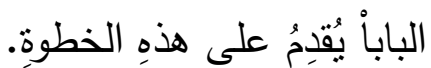

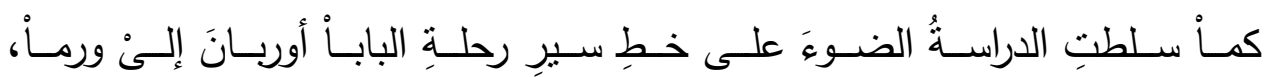

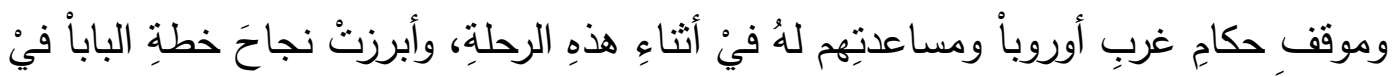

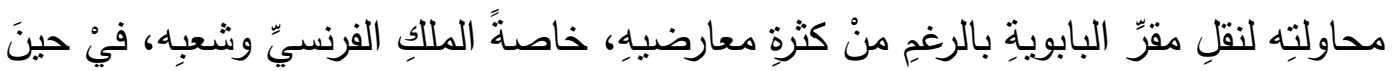

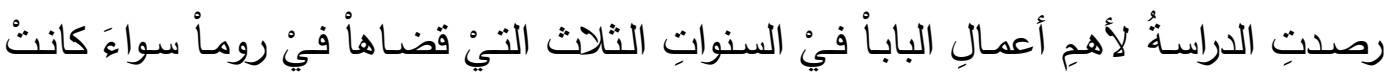

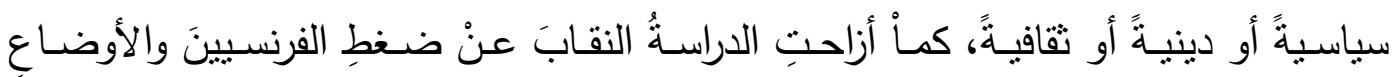

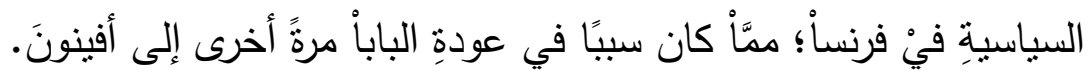

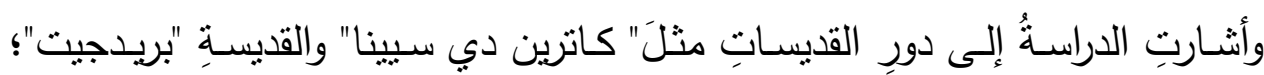

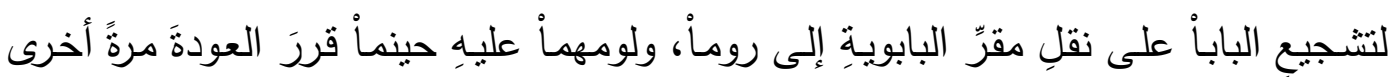
إلى أفينونَ. 
قائمة المختصرات الواردة بالبحث

\begin{tabular}{|l|l|}
\hline APS: & American Philosophical Society. \\
\hline AV: & Archives du Vatican. \\
\hline BSMR: & Bibliotheca scriptorum Medii Recentisque Aevorum \\
\hline CNRS: & Centre National de Recherché Scientifique. \\
\hline DOC: & Documents. \\
\hline Ec: & Ecclesiastici \\
\hline HYW: & Hundred Years War. \\
\hline N: & Number. \\
\hline Nos: & Numbers. \\
\hline Not: & Footnote. \\
\hline
\end{tabular}

\section{قائمة المصادر والمراجع}

\section{أولًا : المصادر الأجنبية:}

1) Albanès, J. H., Vies antiques du pape Urbbain V (par des auteurs cintemporains autres anterieur au XVI siècle), Actes anciens et documents concernant le bienheureux Urbain V, pape, sa famille, sa personne, son pontificat, ses miracles et son culte, et publiés par le chanoine Ulysse Chevalier 1897.

2) Augustin Theiner, Codex diplomaticus dominii temporalis S. Sedis, extraits des Archivio du vaticano, Tome II (1335-1389), Rome 1862.

3) Benjamin of Tudela, The Travels of Benjamin of Tudela, ed. Th. Wright, London, 1948.

تم الاعتماد على الترجمة العربية لهذه المصدر تحت عنوان:

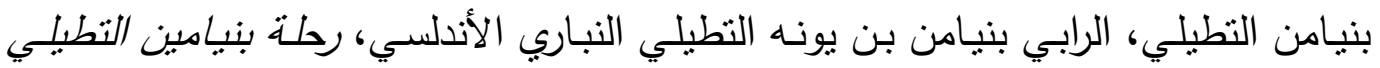

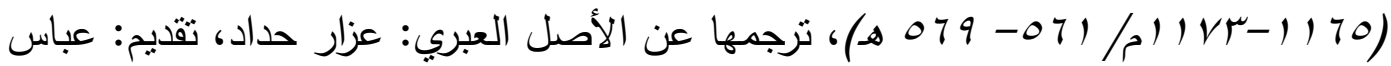

$$
\text { العزاوي، الطبعة الأولى، بغداد } 9 \text { ام ام. }
$$

4) Chevalier de L'escale, La vertu resuscitée, ou la vie du Cardinal Albornoz, urnomme ere de leglise, Tome 6, Paris 1629.

5) Chronicon, Veterum scriptorum et monumentorum historicorum, $\mathrm{T}$. V, Paris 1729. 
6) Chronographia regum Francorum (1270-1380), éd. H. Moranville, Tome 2, Paris 1891-1893.

7) Cibrario, L., Storia della monarchia di Savoia, Vol.3, Torino 1844.

8) Dante, A., La Devine comédie, trad. H. Largnon et G. Frères, Paris, 1966.

9) Emule, F., Historia Bibliothecae Romanorum Pontificum, Rome 1890.

10) Fracois Amadi, Chroniques d'Amadi, publiee par Rene de Mas Latrie, Paris 1893.

11) Francesco Antonio Vitale, Storia diplomatica de' senatori di Roma dalla decadenza dell'imperio Romano, Tome I, Roma 1791.

12) François Du Chesne, Histoire de tous les Cardinaux François de Naissance, 2 Tomes, Paris 1660.

13) František Martin Pelcl, Geschichte Kaiser Karls des Vierten, Königs in Böhmen, Enthält die Jahre 1355 bis 1378, nebst einem Urkundenbuche von ein hundert ein und vierzig izt erst gedruckter Diplomen und Briefe, 2 Vols. Walther 1783.

14) Fréville R., Bibliothèque de l'école des Chartes, Tome 5, Paris $1843-1844$.

15) Froissart, J., Chronicles of the England, France, Spain and the adjoining countries, from the latter part of reign of Edward II to the Coronation of Henir IV, translated from the French by Th. Johnes, Vol. 1, London 1901.

16) Froissart, J., Les Chroniques, dans: Historiens et Chroniqueurs $d u$ Moyen Age, texte établi et annoté par A. Pauphilet, Gallimard, Bruges 1963.

17) Gobelinus Persona, Cosmodromium, hoc est Cronicon vniuersale, complectens res Ecclesiae et reipublicae ab orbe condito usque ad annum Christi 1418, Francofurti 1599.

18) Gregorovius, Ferdinand, History of the city of Rome in the middle ages, Translated from the Fourth German edition by A. Hamilton, Vol. VI, Part. II, London 1898.

19) Hefele, C., Histoire des conciles d'après les documents originaux, traduite de l'Allemand, M. l'Abbe Delarc, Tome 9, Paris 1873.

20) Johann Peter Kirsch, Die Ruckkehr der Pdpste Urban V. und Gregor XI. von Avignon nach Rom: Ausziige aus den Kameralregistern des Vatikanischen Archivs, Paderborn, 1898.

21) L' Abbe M. Chaillan, Le bienheureux Urbain V (1310-1370), deuxieme edition, Librairie Victor Lecoffre, Paris, 1911. 
22) L' Abbé Magnan, Histoire d'Urbain V et de son siècle d'après les manuscrits du Vatican, Paris 1863.

23) L. Tautu, Act Urbani V (1362-1370), et Regestis Vaticanis aliisqu Fontibus Collegit, Rome 1964.

24) L'abbé Rose, Etudes historiques et religieuses sur le XIV siècle, Avignon 1842.

25) Leonce Macheras, Chronique de Chypre, Traduction Francaise par E. Miller, Paris 1882.

26) Lodovico Antonio Muratori, Annali d'Italia dal principio dell'era volgare sino all'anno 1750, T. 8, Lucca 1763.

27) M. Louis Moreri, Le grand dictionnaire historique ou le mélange curieux de l'histoire sacrée et profane, Vol. 10, Paris 1759.

28) M. N. Bouillet, Dictionnaire universel d'histoire et de géographie, Paris 1878.

29) M. Simeon, Chronique des quatre premiers Valois (1327-1393), Paris 1861.

30) Machaut G., La prisa de l'Alexandrie ou cronique de roi Pierre Ier Lusiguan, Publice par Mas Latrie,Geneve 1877.

31) Matteo Villani, Istorie di Matteo Villani cittadino fiorentino. Checontinua quelle di Giouanni suo fratello Con l'aggiunta di Filippo suo figliuolo, che arriuano sino all'anno 1364 (2 Tomes), Firenze 1581.

32) Maurice, Prou, Etude sur les relations politiques du pape Urbain V avec les Rois de France Jean II et Charles V (A.V.), Paris 1888.

33) P. Gasnault and M. H. Laurent (eds.), Innocent VI: Lettres secretes et curiales, Paris 1959.

34) Pastor (L.), Histoire des papes, depuis la fin du Moyen Age, Traduit de l'allemande par Furcy Raynaud, Tome 1, Paris, 1888.

35) Petraque, F., Les rimes de François Petraque, trad. F. Reynard, Paris 1883.

36) Raynaldi et Jac. Laderchii, Annales Ecclesiastici, T. 23, BariDucis, Paris 1860; T. 26, Paris 1880.

37) Stephanus Baluzius, Vitae paparum avenionensium: hoc est Historia pontificum romanorum qui in Gallia sederunt ab anno Christi MCCCV usque ad annum MCCCXCIV, Tome I, Paris 1916.

38) Strambldi (Diamede), Chroiques de Strambldi, publiee par Rene de Mas Latrie, Paris 1891.

39) Stubbs, W., Annals of England: An Epitome of English History, London 1876. 
40) Thurocz, J., Chronica Hungarorum, Vol. 1, ed. E. Galántai and J. Kristó, (B.S.M.R.), Series nova, Vol 7, Budapest 1985.

\section{ثانيًا : المصادر العربية والمعربة:}

( ) بنيامن التطيلي، الرابي بنيامين بن بونه التطيلي النباري الأندلسي، رحلة بنبامبن

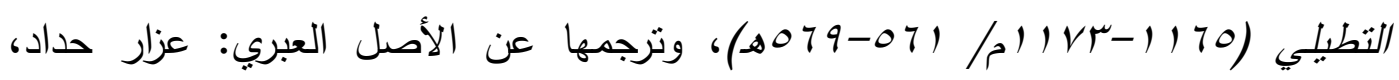
تقديم: عباس العزاوي، الطبعة الأولى، بغداد 0 ـ ام.

r) الإدريسي، (أبوعبدالله محمد بن إدريس بن يحيى بن حمود الحسيني المعروف بالشريف

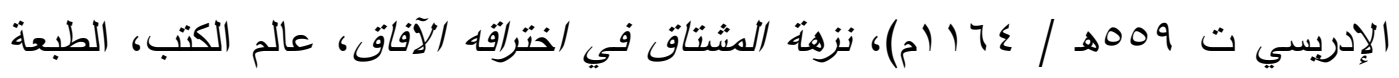

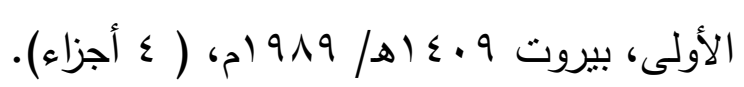

r) أبو الفداء (عماد الدين إسماعيل بن محمد بن عمر المعروف بأبي الفداء ت بrVه)، تقوبم البلدان، مكتبة التقافة الدينية، بدون تاربخ.

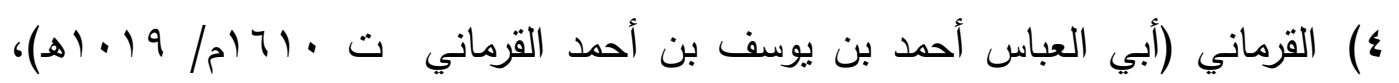
أخبار الدول وآثار الأول في التاريخ، الجزء الثالث، تحقيق: فهمي سعد وأحمد حطيط، عالم

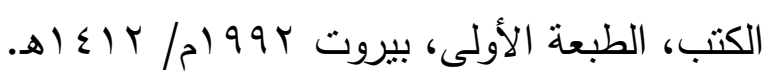

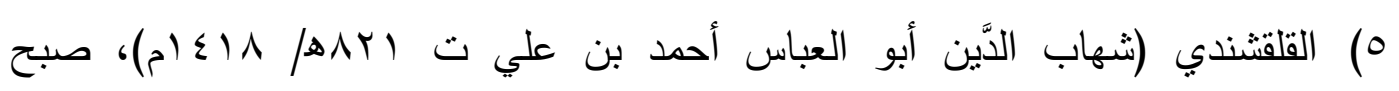

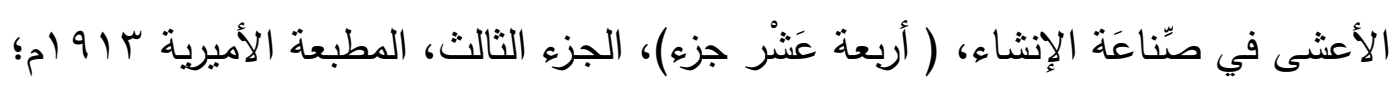

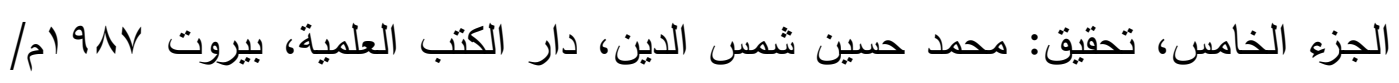
(ه. $\varepsilon$

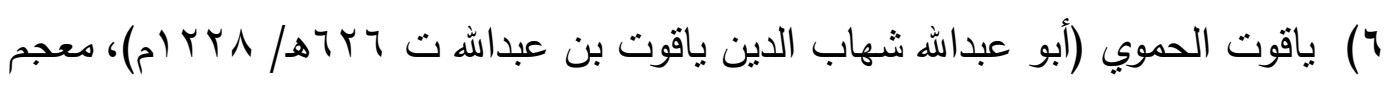
البلدان، الجزءان الثاني والثالث، دار الكتب العلمية، بيروت بدون تاريخ.

ثالثًا - المراجع الأجنيـة:

1) Atiya, A. S., The Crusade in the Later Middle ages, London 1938.

2) Ayton, A., Philip Preston, The Battle of Crécy, 1346, Boydell Press 2005.

3) Bréhier, D., Notre Dame de Doms, éd. Beaulieu, Lyon 2002.

4) Bréhier, L., Le monde Byzantin: vie et morte de Byzance, Paris 1946.

5) Burne, A. H., The Crecy War: Military History of the Hundred Years War from 1337 to the Peace of Bretigny, 1360. Eyre \& Spottiswoode, 1955. 
6) Caffiero, W., John Hawkwood: An English Mercenary in FourteenthCentury Italy. Baltimore: Johns Hopkin University Press 2006.

7) Charanis, P., "A Important Short chronicle of the Fourteenth century", B. I, Vol. XIII, Bruxelles 1938.

8) Poulet, Ch., Guelfes et Gibelins, Vromant, Tome.2, Bruxelles, 1922.

9) Chelini, J., L'Eglise au temps des Schismes 1294 -1449, Armad Colin, Paris 1982.

10) Chevalier, U., Répertoire des sources historiques de moyen age, New York 1960.

11) Christophe, J. B., Histoire de la Papauté pendant le xive siècle, Tome. 2, Paris 1853.

12) Collier, W. F., The Great Events of History, London 1890.

13) Datta, P., Spedizione in Oriente di Amedeo VI. Conte di Savoia, Torino 1826.

14) Delachenal, R., Histoire de Charles V, Tome 3, Paris 1916.

15) Denifle, H., La désolation des églises, monastères et hôpitaux en France pendant la Guerre de Cent ans, Tome II, Paris 1899.

16) Doukas, M., Decline and Fall of Byzantium to the Ottoman Turks, trans. By Harry, J. M., Detroit, London 1975.

17) Werunsky, E., Geschichte Kaiser Karls IV und seiner Zeit, New York 1961.

18) Encyclopadia Universalis, Thesaurus. Index, Editeur à Paris 1988.

19) George, L., Historical Dictionary of Poland, 966-1945. Abcclioo Press, London 1996.

20) Gibbons, H. E., The foundation of the Ottoman Empire: A History of the Osmanlis up to the death of Bayezid (1300-1403), Oxford 1916.

21) Girard, J., Evocation du vieil Avignon, Paris 1990,

22) Halecki, O., Un Empereur de Byzance a Rome, Variarum Reprints, London 1972.

23) Hammer, J., Histoire de l'empire Ottoman, Tr. From Germany J.J. Heart, Tome I, London 1931.

24) Hanson, J. L., A dictionary of Economics and Commerce, London 1975.

25) Hayez, M., Avignon sans les Papes (1367-1370, 1376-1379), dans Genèse et débuts du Grand Schisme d'Occident, éd. C. N. R. S, Paris 1980.

26) Homo, L., Rome medieval, 476-1420, Paris 1956.

27) Moorman, J.R., History of the Franciscan Order from its origins until the year 1517, London 1968.

28) Kelly, J. N. O., The Oxford Dictionary of Popes, Oxford 1996. 
29) Kuhner, H., Encylopedia of the Papacy, London 1996.

30) Moore, W. G., The Penguin Encyclopedia of places, New York 1978.

31) Morganstern, A.M., "The La Grange Tomb and Choir: A Monument of the Great Schism of the West", Speculum, Vol. 48, No. 1 (Jan., 1973), pp. 52-69.

32) Osborne J., "Lost Roman Images of Pope Urban V (1392-1370) for Julian Gardner", Zeitschrift fur Kunstgeschichte 54/1 (1991).

33) Partner, P., The Lands of St. Peter. The Papal State in the Middle Ages and the Early Renaissance, London 1972.

34) Engel, P., A History of Medieval Hungary 895-1526. London 2001.

35) Pirenne, H., Augustin Renaudet, La fin du moyen age la desagregation du monfe medieval (1285-1453), Tome. I, Paris 1931.

36) Prou, M., Etudes sur les relations politiques du pape Urbain V avec les rois de France Jean II et Charles V, Paris 1888. (Extraits très copieux des (A. V.).

37) Renouard (Y.), La Papauté à Avignon, Presses, universitaires de France, Paris 1954.

38) Rohrbacher (R.F.), Dufour (A.H.), Histoire universelle de l'eglise catholique, Tome 20, Paris 1938.

39) Sara, S.M., Petrarch's Laurels, Pennsylvania State University Press 2010.

40) Setton, K. M., "The Papacy and the Levant, 1204-1571", In: The thirteenth and fourteenth centuries, Vol. I, American Philosophical Society 1976.

41) Stephenson, C., Medieval History, New York 1943.

42) Mollat (G), Les Papes d'Avignon (1305-1378), $3^{\text {ème }}$ éd. Librairie Victor Lecoffre, Paris 1920.

43) Mollat (G.), Samaran (Ch.), La Fiscalité pontificale en France au XIVème siècle, Thorin et fils, Paris 1905.

44) Najemy, M. J., History of Florence 1200-1575, London 2006.

45) Nicol, D., M., The Last Centuries of Byzantium, 1261-1453, London 1972.

46) Villalon, A. L. J., "Spanish Involvement in the Hundred years war and the Battle of Najera", In Hundred Years War: a wider Focus, ed. Villalon A. and Kagay D., Boston 2005.

47) Wagner J., Encyclopedia of the Hundred Years War, London 2006. 
(أحمد عبدالرحيم، أصول في التاربخ العثماني، دار الثروق، الطبعة الثانية، بيروت - م) 917 ب)درويش النخيلي، السُفُن الإسلامبية على حروف المعجم، الطبََّْة الثانية، دار المعارف، الإسكندرية 9 (م)

ب)دونالد نيكول، دعجم التراجم البيزنطبة، ترجمة: حسن حبثي، الهيئة المصرية العامة

$$
\text { للكتاب، القاهرة ب. . . ץ.م. }
$$

ع)زيادة أبوغنمية، جوانب مضيئة في تاربخ العثانبين الأتراك، دار الفرقان، الطبعة الأولى،

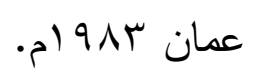

ه)رينيه جروسيه، موجز تاربخ الحروب الصليبية في المشرق الإسلامي، ترجمة: أحمد

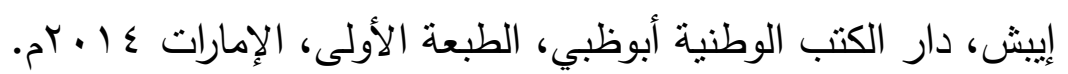

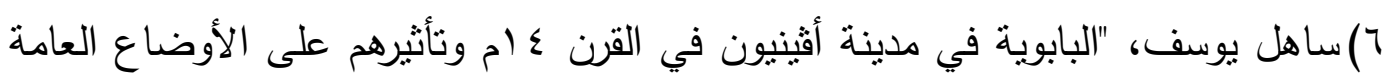
في أوروبا الكاثوليكية"، رسالة ماجستير، كلية العلوم الإنسانية والاجتماعية -جامعة

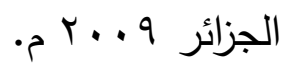

V) سعيد عبدالفتاح عاشور، أوروبا العصور الوسطى ( النظم والحضارة)، الجزء الثاني، مكتبة النهضة المصرية، القاهرة 909 (م.

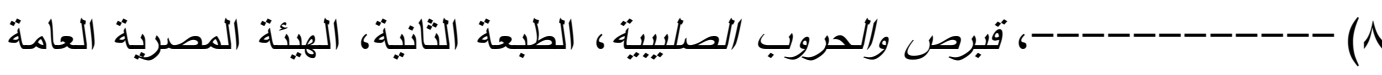

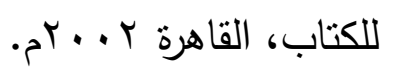

9) عادل هلال، العلاقات بين المغول وأوربا وأثرها على العالم الإسلامي، دار عين

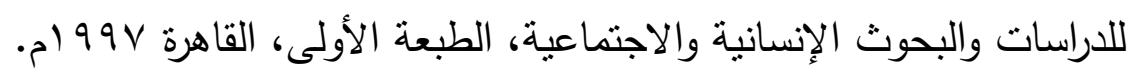
• (1) ثيليهم هايد، تاربخ التجارة في الثرق، ترجمة: أحمد رضا، الجزء الثاني، الهيئة المصرية العامة للكتاب، القاهرة 1999 م.

(1) عبد الرحمن بن عبداله بن عبد المحس، "صكوك الغفران عند النصارى"، مجلة العلوم

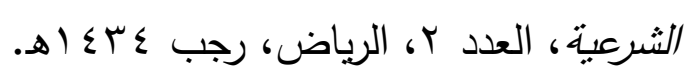

r ( ) محمد أحمد دهمان، معجم الألفاظ التَِِّيِية، مجلة التقافة الإسلامية، العدد 0 (، سنة

$$
\text { . } 1 \leqslant \cdot \Lambda
$$

با) محمد فريد بك المحامي، تاربخ الدولة العلية العثمانية، تحقيق: إحسان حقي، دار

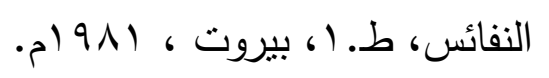


ع ( ) محمد فؤاد كوبريلي، قيام الدولة العثانية، ترجمة: أحمد السعيد، دار الكاتب العربي، القاهرة، بدون تاريخ. 0 (1) محمود سعيد عمران، المغول وأوروبا، دار المعرفة الجامعية، بدون تاريخ. 7 1) وفاء بنت عبداله المزروع، "انثقاق البابوية في العصور الوسطى وأثزه على الأوضاع

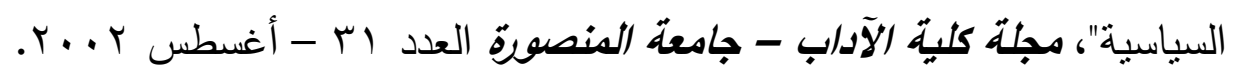
(IV ول وايريل ديورانت، قصة الحضارة، مجلد 0، الجزء الأول، ترجمة: محمد بدران، تونس، بدون تاريخ. 